\title{
G Protein-Coupled Receptors Targeting Insulin Resistance, Obesity, and Type 2 Diabetes Mellitus
}

\begin{abstract}
Darren M. Riddy, Philippe Delerive, Roger J. Summers, Patrick M. Sexton, and Christopher J. Langmead
Drug Discovery Biology, Monash Institute of Pharmaceutical Sciences, Monash University, Parkville, Victoria, Australia (D.M.R., R.J.S., P.M.S., C.J.L.); and Institut de Recherches Servier, Pôle d'Innovation Thérapeutique Métabolisme,
\end{abstract} Suresnes, France (P.D.)

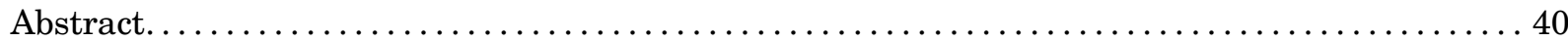

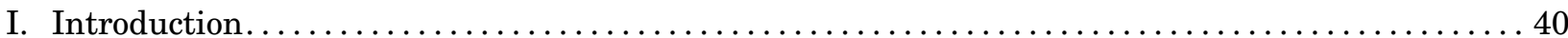

A. Pathophysiology and Diagnosis of Type 2 Diabetes Mellitus .................. 40

B. $\beta$-Cell Dysfunction and Insulin Resistance . . . . . . . . . . . . . . . . . . . . . . . . . . 40

C. Obesity-Induced Type 2 Diabetes Mellitus . . . . . . . . . . . . . . . . . . . . . . . . . . . 41

D. Involvement of G Protein-Coupled Receptors $\ldots \ldots \ldots \ldots \ldots \ldots \ldots \ldots \ldots \ldots \ldots \ldots \ldots \ldots 43$

II. G Protein-Coupled Receptors and $\beta$-Cell Dysfunction and Insulin Resistance ............. 43

A. Adrenoceptors................................................ 43

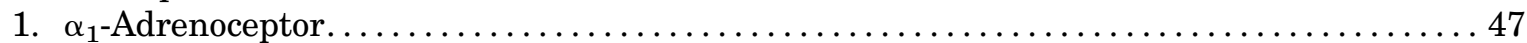

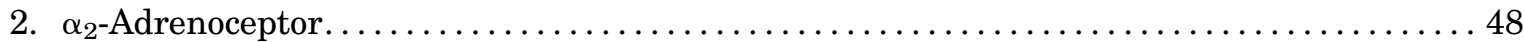

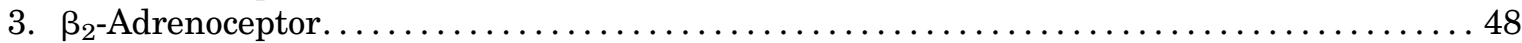

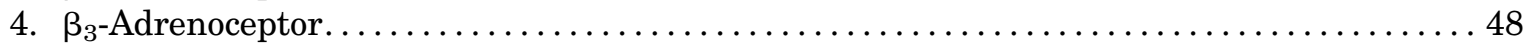

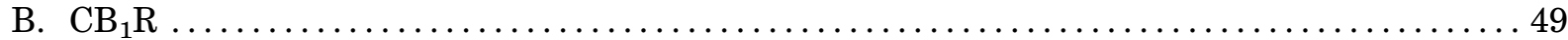

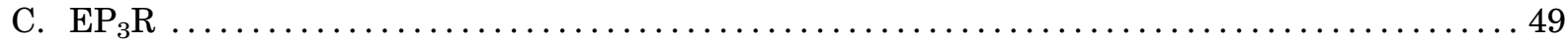

D. Free Fatty Acid Receptors: FFAR1, FFAR2, and FFAR3 (GPR40, GPR43, and GPR41) ... 49

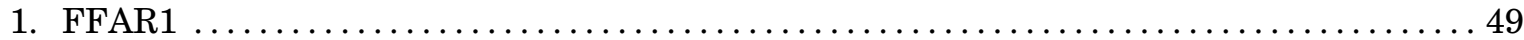

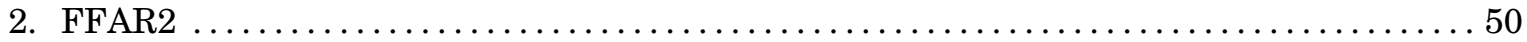

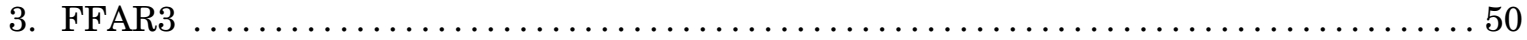

E. Glucagon-Like Peptide 1 Receptor. ................................... 50

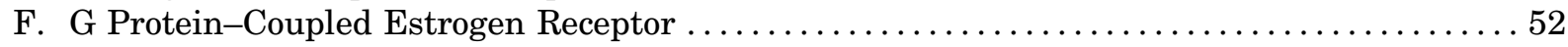

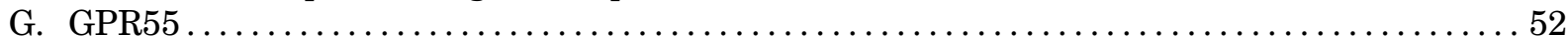

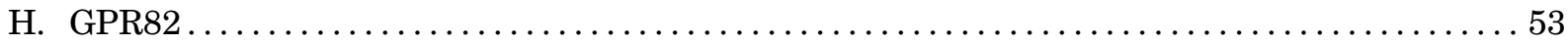

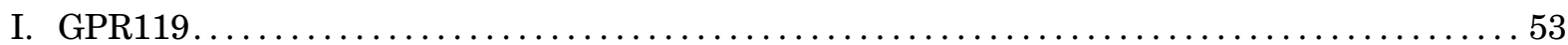

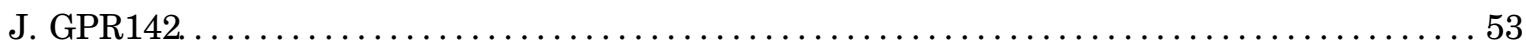

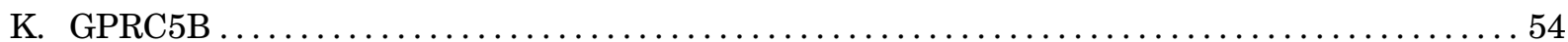

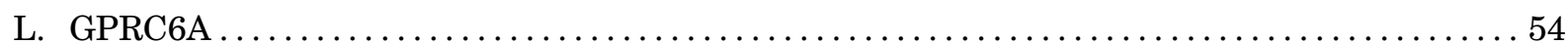

M. Hydroxycarboxylic Acid Receptor 2 (GPR109A) . . . . . . . . . . . . . . . . . . . 55

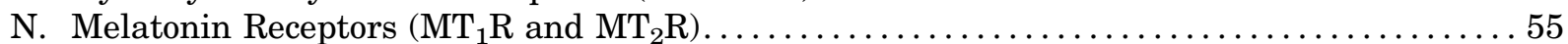

III. G Protein-Coupled Receptors and Obesity-Induced Type 2 Diabetes Mellitus .............. 56

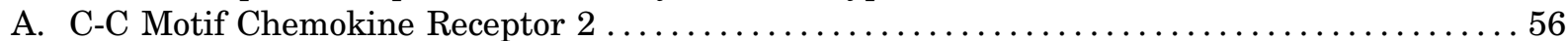

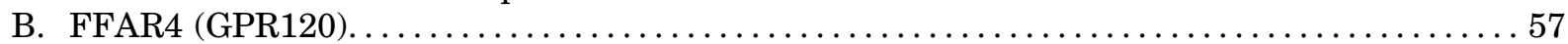

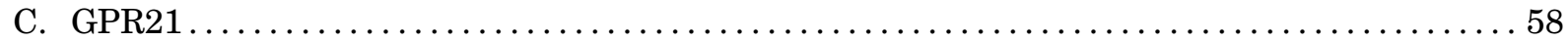

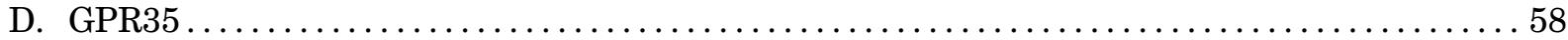

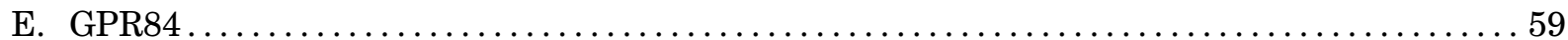

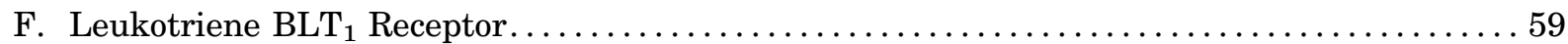

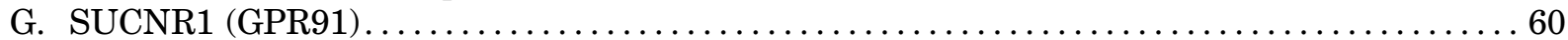

This work into G protein-coupled receptors, type 2 diabetes mellitus, and insulin resistance was partially supported by Institut de Recherches Servier (Paris, France). P.M.S. is a Principal Research Fellow of the National Health and Medical Research Council of Australia. http://doi.org/10.1124/pr.117.014373.

Address correspondence to: Dr. Christopher J. Langmead, Drug Discovery Biology, Monash Institute of Pharmaceutical Sciences, Monash University, 381 Royal Parade, Parkville, VIC 3052, Australia. E-mail: chris.langmead@monash.edu 


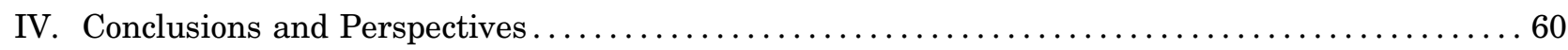

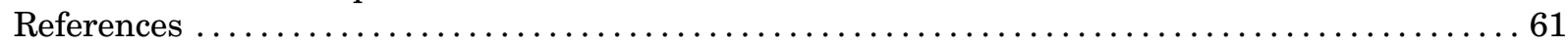

Abstract_-G protein-coupled receptors (GPCRs) continue to be important discovery targets for the treatment of type 2 diabetes mellitus (T2DM). Many GPCRs are directly involved in the development of insulin resistance and $\beta$-cell dysfunction, and in the etiology of inflammation that can lead to obesityinduced T2DM. This review summarizes the current literature describing a number of well-validated GPCR targets, but also outlines several new and promising targets for drug discovery. We highlight the importance of understanding the role of these receptors in the disease pathology, and their basic pharmacology, which will pave the way to the development of novel pharmacological probes that will enable these targets to fulfill their promise for the treatment of these metabolic disorders.

\section{Introduction}

\section{A. Pathophysiology and Diagnosis of Type 2 Diabetes Mellitus}

Data from the International Diabetes Federation Atlas (2015) indicates that over 415 million people have been diagnosed with diabetes, a figure that by 2040 is projected to rise to more than 642 million. In almost $90 \%$ of cases, the patients have been diagnosed with type 2 diabetes mellitus (T2DM). Although countries such as China, Brazil, and the United States have the largest number of people with T2DM, it is predicted that countries in the Middle East and Africa will soon have the greatest increase in prevalence. Clinically it is proving difficult to determine the onset of T2DM, with estimates of 5-10 years prior to diagnosis being suggested (Cooper, 2012). Typically, in the first 2 years following diagnosis, pancreatic $\beta$-cell function can decrease by $40 \%-70 \%$, indicating that early diagnosis is critical to identifying the most suitable patient care (Cooper, 2012).

Current therapies for T2DM focus on restoring glycemia levels to those of healthy subjects. The American Diabetes Association has recommended that the glycemic goal for T2DM patients be an $\mathrm{HbA} 1 \mathrm{c}$ level $\leq 7 \%$, with an optimal level of $6.5 \%$. Traditionally treatments for T2DM have focused on pancreatic $\beta$-cell dysfunction and insulin resistance; however, additional pathophysiological mechanisms associated with T2DM, including hyperglucagonemia in pancreatic $\alpha$-cells, increased glucose reabsorption in the kidneys (Mazzola, 2012) and tissue inflammation (Donath, 2014), are gaining greater recognition. Due to a close link between obesity and T2DM, the initial treatment prescribes a change in lifestyle with a specific focus on diet and inactivity. However, current adherence of obese and/or prediabetic patients to lifestyle recommendations to prevent the development of overt T2DM is low. Furthermore, the impact of intensive lifestyle intervention focusing on weight loss does not significantly reduce the rate of cardiovascular events in obese with T2DM (Wing et al., 2013). Therefore, pharmacological intervention is often eventually required to aid in glycemic control (García-Pérez et al., 2013).

T2DM is a multifaceted disease involving pancreatic $\alpha$ - and $\beta$-cells, skeletal muscle, adipose tissue, liver, intestine, kidney, and the central nervous system (CNS) (DeFronzo, 2009; Lin and Sun, 2010). In healthy people, during fasting conditions, glucagon is released from $\alpha$-cells in the liver (Gylfe and Gilon, 2014), which helps to maintain normal blood glucose concentrations. Following food intake, blood glucose levels increase, and this, in turn, causes the pancreas to secrete insulin from pancreatic $\beta$-cells to inhibit glycogenolysis and gluconeogenesis and increase glycogen synthesis (Perley and Kipnis, 1967). In addition, the biologically active incretin hormones, glucagon-like peptide 1 (GLP-1) and glucosedependent insulinotropic polypeptide (GIP), are released from endocrine cells following food intake, and act on GLP-1 receptor (GLP-1R) and GIP receptors expressed on pancreatic $\beta$-cells, causing a direct potentiation of insulin secretion. Furthermore, insulin increases blood glucose uptake by skeletal muscle and adipose tissue, mediated by translocation of glucose transporter 4 (GLUT4) (Mueckler, 1992). Insulin also promotes the storage of glucose as glycogen in the liver and inhibits lipolysis from adipose tissue (Kalupahana et al., 2012). Once blood glucose levels revert to normal, insulin secretion ceases and normoglycemia is restored (Wilcox, 2005).

\section{B. $\beta$-Cell Dysfunction and Insulin Resistance}

Glucose-stimulated insulin secretion from $\beta$-cells occurs due to an increase in calcium $\left(\mathrm{Ca}^{2+}\right)$ influx into the cell following closing of ATP-sensitive potassium $\left(\mathrm{K}^{+}\right)$channels and activation of the protein kinase $\mathrm{C}$

ABBREVIATIONS: CCL, C-C-chemokine ligand; CCR, C-C motif chemokine receptor; CNS, central nervous system; ER, endoplasmic reticulum; FFA, free fatty acid; FFAR, FFA receptor; GLP-1, glucagon-like peptide 1; GLP-1R, GLP-1 receptor; GLUT4, glucose transporter 4; GPCR, G protein-coupled receptor; GPER, G protein-coupled estrogen receptor; $\mathrm{HCA}_{2}$, hydroxycarboxylic acid receptor 2; IL, interleukin; IKK, inhibitor of $\kappa \mathrm{B}$ kinase; IRS, insulin receptor substrate; JNK, c-Jun N-terminal kinase; KO, knockout; LPS, lipopolysaccharide; LTB 4 , leukotriene $\mathrm{B}_{4}$; MCFA, medium-chain fatty acid; MCP, monocyte chemoattractant protein; MT, melatonin; NASH, nonalcoholic steatohepatitis; NF- $\kappa$ B, nuclear factor $\kappa$ light-chain enhancer; OCN, osteocalcin; PKC, protein kinase C; SCFA, short-chain fatty acid; SDH, succinate dehydrogenase; siRNA, small interfering RNA; T2DM, type 2 diabetes mellitus; TALENS, transcription activator-like effector nucleases; TGF, transforming growth factor; Th, T helper; TNF, tumor necrosis factor. 
(PKC) signaling pathway (Cooper, 2012). A decrease in insulin-stimulated glucose uptake in insulin-sensitive tissues such as skeletal muscle is termed insulin resistance and leads to progressive hyperglycemia (Fig. 1) (Olefsky and Glass, 2010). The molecular mechanism by which insulin resistance occurs includes activation of the serine/threonine kinase pathway by translocation of $\mathrm{PKC} \varepsilon$, leading to phosphorylation of insulin receptor substrate (IRS)-1 (Morino et al., 2006). Furthermore, dysregulation in the levels of ceramides, sphingolipids, triacylglycerols, and diacylglycerols, through an increase in dietary fat sources, can further impair IRS phosphorylation, culminating in a deficiency of the downstream signaling of the insulin cascade (Galbo et al., 2013; Camell et al., 2015; Iqbal et al., 2017). An increase in these ectopic lipids is associated with complications of T2DM, including nonalcoholic fatty liver disease and nonalcoholic steatohepatitis (NASH) (Shulman, 2000; Samuel and Shulman, 2012).

Phosphorylation of IRS-1 promotes negative feedback that interferes with normal insulin signaling (Cooper, 2012). This reduced function in insulin-sensitive tissues causes pancreatic $\beta$-cells to increase insulin secretion and cellular mass (Donath and Shoelson, 2011; Cerf, 2013). Activation of membrane-bound G proteincoupled receptors (GPCRs) enhances insulin secretion via $\mathrm{PKC}$ activation or through an increase in cAMP, which activates protein kinase $\mathrm{A}$ and potentiates the $\mathrm{Ca}^{2+}$ influx (Heit et al., 2006; Vangoitsenhoven et al., 2012 ). An increase in pancreatic $\beta$-cell proliferation has been suggested to be caused by signaling through IRS-2, which causes protein kinase B phosphorylation, and inhibition of the forkhead-O transcription factor 1
(Heit et al., 2006; Prentki and Nolan, 2006). Expression of the transforming growth factor (TGF) $\beta$ superfamily signaling inhibitor, SMAD7, in pancreatic $\beta$-cells, has also been implicated as it promotes cell proliferation in vivo by increasing CyclinD1 and CyclinD2 expression (Xiao et al., 2014). The increased insulin secretion is initially sufficient to overcome the higher demand, but over time exhausted $\beta$-cells cannot cope with the increased insulin demand, resulting into exacerbated insulin resistance (Chawla et al., 2011; Kalupahana et al., 2012; Lee and Lee, 2014).

It is important to note that T2DM may develop as a consequence of early $\beta$-cell dysfunction in certain patients, whereas in others insulin resistance precedes the defects in the $\beta$-cells (Færch et al., 2013, 2015). $\mathrm{T} 2 \mathrm{DM}$ is therefore considered as a very heterogeneous disease.

\section{Obesity-Induced Type 2 Diabetes Mellitus}

In recent years, evidence has emerged linking immune cell infiltration into adipose tissue to causes of chronic low-grade inflammation (Fig. 2) that has a key role in the pathogenesis of obesity-induced insulin resistance (Olefsky and Glass, 2010; Chawla et al., 2011; Donath and Shoelson, 2011; Shu et al., 2012; Krinninger et al., 2014). Although these changes can be ascribed to the natural ageing process, there is a contribution from increasingly sedentary lifestyles and the consumption of high-fat foods that causes a change in metabolic and immune cells, including adipocytes and macrophages (Tanti et al., 2013). Further insight into the mechanistic link between insulin resistance and inflammation has revealed activation of $B$ cells by

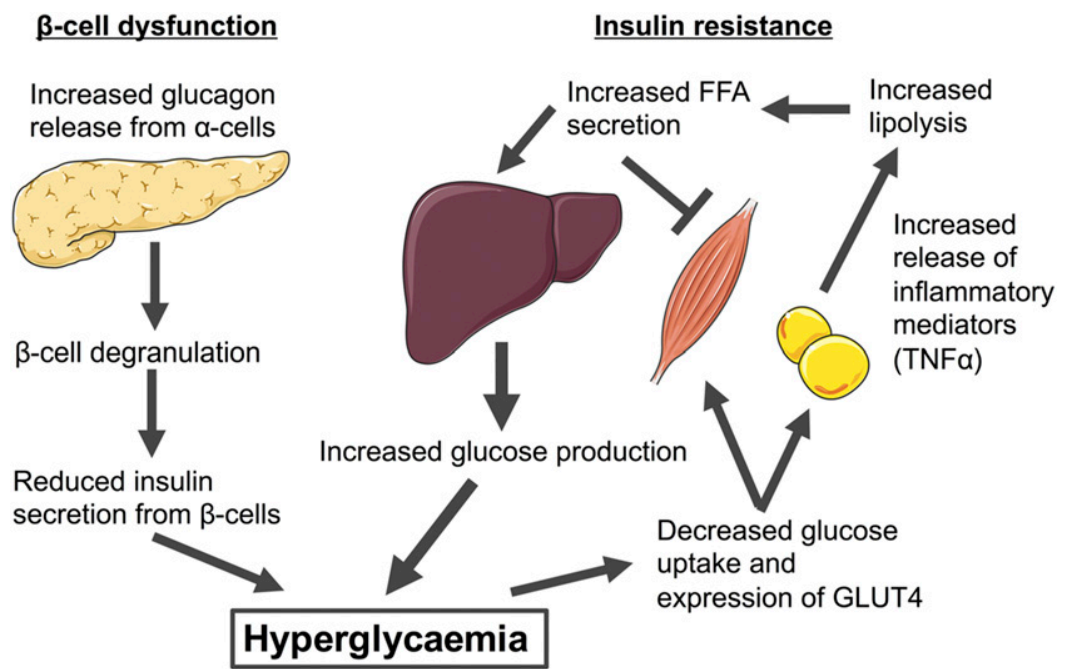

Fig. 1. Pathology of T2DM. $\beta$-cell dysfunction occurs following insult from increased FFA levels, obesity, insulin resistance, and inflammation. Initially the $\beta$-cell compensates by increasing the release of insulin; however, over time this compensatory mechanism fails and reduction in $\beta$-cell mass is evident. The loss of $\beta$-cell mass occurs from cellular degranulation, resulting in an increase in glucagon from $\alpha$-cells and a decrease in insulin secretion. The reduced plasma insulin results in an increase in glucose levels. Glucose-sensitive tissues, including skeletal muscle and adipocytes, are unable to accommodate the increased glucose concentration. Increased fat accumulation in adipocytes also leads to an increase in proinflammatory cytokine release and increased lipolysis. A further release of FFAs stimulates the liver to increase glucose production. Persistent glucose release preserves the hyperglycemic environment, leading ultimately to T2DM. 
$\underline{\text { Insulin sensitivity }}$

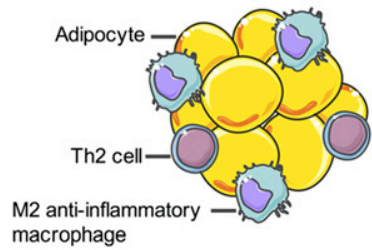

Secretion of anti-inflammatory mediators (e.g. IL-4, IL-13)

\section{Insulin resistance}

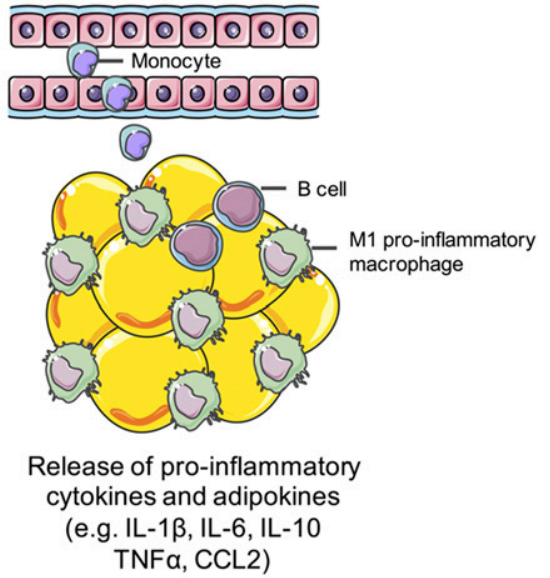

Increased gluconeogenesis in liver and skeletal muscle

Fig. 2. Inflammation and insulin resistance. Under normal conditions, tissue-resident M2 macrophages surround adipocytes and secrete antiinflammatory mediators, including IL-4 and IL-13, maintaining an insulin-sensitive environment. Increased levels of nutrients, including fat, FFAs, and proinflammatory mediators, result in adipocyte hypertrophy, lipolysis, and ER stress. In addition, further release of proinflammatory mediators, including IL-6, IL-10, and CCL2 (MCP-1), results in transition, differentiation, and polarization of the tissue-resident M2 macrophages into M1 proinflammatory macrophages. Furthermore, recruitment and differentiation of circulating peripheral blood monocytes result in an increase in the proinflammatory milieu. Other metabolic tissues, including the liver and skeletal muscle, are also susceptible to the increased levels of cytokine production, ER stress, and macrophage recruitment, resulting in an increase in glucose production, fueling the hyperglycemic state further.

nuclear factor $\kappa$ light-chain enhancer $(\mathrm{NF}-\kappa \mathrm{B})$ and the inhibitor of $\kappa \mathrm{B}$ kinase (IKK) $-\beta$, resulting in an increase in the expression and release of proinflammatory cytokines and in expression of their cognate receptors (Donath and Shoelson, 2011; Osborn and Olefsky, 2012). Similarly, the suppressor of cytokine signaling protein family, which interacts directly with Janus-activated kinases, is upregulated in obese patients (Tanti et al., 2013). Activation of the c-Jun N-terminal kinase (JNK) pathway, which is increased in obesity, causes a further release of proinflammatory cytokines in response to $\mathrm{NF}-\kappa \mathrm{B}$ activation (Donath and Shoelson, 2011).

Schroder et al. (2010) demonstrated that the inflammasome, which contains the nucleotide-binding oligomerization domain-like receptor, caspase-1, and the apoptosis-associated speck-like protein containing a caspase recruitment domain adapter protein, was capable of controlling the secretion of proinflammatory cytokines, including interleukin (IL)- $1 \beta$ and IL-18. Increased activation of the inflammasome has also been observed in macrophages of obese animals and humans, in which the levels of caspase- 1 and IL- $1 \beta$ are significantly upregulated (Tanti et al., 2013; Esser et al., 2014, 2015). Furthermore, obese mice lacking nucleotide-binding oligomerization domain like protein pyrin domaincontaining 3 displayed improved insulin resistance and glucose homeostasis as a direct result of a reduction in IL-18 and interferon- $\gamma$ expression and an enhancement in insulin signaling (Vandanmagsar et al., 2011).

The relationship between inflammation and insulin resistance is not new because benefits on glycemic control have been noted in diabetic patients taking sodium salicylate, the active ingredient in the nonsteroidal antiinflammatory drug, aspirin (Williamson, 1901). Unfortunately, this theory was not reconsidered until 1993, when it was demonstrated that tumor necrosis factor (TNF)- $\alpha$ was expressed in the adipose tissue of obese animals and insulin-resistant patients (Hotamisligil et al., 1993, 1995), thus identifying a direct connection between obesity, inflammation, and insulin resistance.

Under normal conditions, M2 macrophages surround adipocytes in adipose tissue and secrete antiinflammatory mediators, including IL-4 and IL-13, that maintain an insulin-sensitive environment (Fig. 2). Increased levels of nutrients, including fat, free fatty acids (FFAs), and proinflammatory mediators, cause adipocyte hypertrophy, lipolysis, and endoplasmic reticulum (ER) stress (Hotamisligil, 2010). In addition, further release of proinflammatory mediators, including IL-6, IL-10, and C-C-chemokine ligand (CCL) 2 [also known as monocyte chemoattractant protein (MCP)-1], results in differentiation and polarization of antiinflammatory M2 macrophages into M1 proinflammatory macrophages. Furthermore, recruitment and differentiation of circulating peripheral blood monocytes result in an increase in the proinflammatory milieu. Other metabolic tissues, including the liver and skeletal muscle, are also susceptible to the increased levels of cytokine production, ER stress, and macrophage recruitment, resulting in an increase in glucose production and hyperglycemia.

Current anti-inflammatory targets for the treatment of T2DM include IKK- $\beta-\mathrm{NF}-\kappa \mathrm{B}$ [salsalate; Schwarz Pharma (now part of UCB, Brussels, Belgium) \& 
Elan Pharma, Dublin, Ireland], IL-6 (tocilizumab; Roche, Basel, Switzerland), IL-1 $\beta$ (canakinumab, Novartis, Basel, Switzerland; LY2189102, Eli Lilly, Indianapolis, IN), and TNF- $\alpha$ (CDP571; Celltech Therapeutics, Slough, UK). At present the number of clinical trials evaluating anti-inflammatory compounds and biologics for the treatment of T2DM is limited, with results to date indicating a modest effect on insulin resistance and $\beta$-cell dysfunction (Goldfine et al., 2011, 2013; Esser et al., 2015). Although encouraging, this raises the question of the level of biologic redundancy that exists within these inflammatory pathways, and whether modulation of a single mediator, or pathway, would prevent the development of insulin resistance or T2DM. Moreover, it is still unclear whether low-grade inflammation is the main driver of the development of T2DM or part of a wider pathology (for a comprehensive review, see Kusminski et al., 2016). As the mechanism behind obesity-induced insulin resistance is still unknown, there is still conjecture as to whether targeting inflammation will prove an effective strategy in T2DM (Kraakman et al., 2014; Liu et al., 2016). Therefore, further trials are required to understand whether a relationship exists; such studies may enable investigation into other facets of the disease, including effects on adipocytes and adipose tissue, $\beta$-cell function, and complications that typically arise with T2DM, including microvascular and macrovascular disease (Fowler, 2008) and NASH (Michelotti et al., 2013; Wree et al., 2013).

Although targeting inflammation appears to be potentially a useful approach, targeting different mechanisms to current therapies for T2DM, it is important to note that different preclinical mouse models are divergent in their immune cell populations. For example, BALB/c mice demonstrate a T helper (Th)2-type (anti-inflammatory) cytokine bias, whereas the C57BL/6 strain shows bias toward a Th1-type cytokine phenotype that includes proinflammatory mediators; however, in humans, including those diagnosed with T2DM, there appears to be little or no bias (Lee and Lee, 2014). Greater use of human cells and tissues during target validation and preclinical stages would allow better translation to be achieved earlier, enabling greater confidence in the target and compounds before committing to expensive clinical trials.

\section{Involvement of G Protein-Coupled Receptors}

Currently, there are more than 30 GPCRs that have been implicated in the development and progression of $\beta$-cell dysfunction, insulin resistance, obesity, and T2DM (Fig. 3; Table 1). However, at present, only the GLP-1R has been successfully targeted therapeutically. As this receptor has been comprehensively reviewed (Donnelly, 2012; Meier, 2012; Koole et al., 2013; Cantini et al., 2016; Graaf et al., 2016), it will be discussed only briefly in the following section. Although some of the other receptors listed in Table 1 have been reviewed elsewhere (Ahrén, 2009; Thorburn et al., 2014), these will be mentioned together with a more detailed examination of recently identified GPCRs, many of which are still classified as orphans, making them potentially less well characterized as drug targets for exploitation.

\section{G Protein-Coupled Receptors and $\beta$-Cell Dysfunction and Insulin Resistance}

\section{A. Adrenoceptors}

Activation of the sympathetic nervous system, with consequent release of the catecholamines, adrenaline

\section{$\beta$-cell dysfunction and insulin resistance}

obesity-induced
insulin resistance

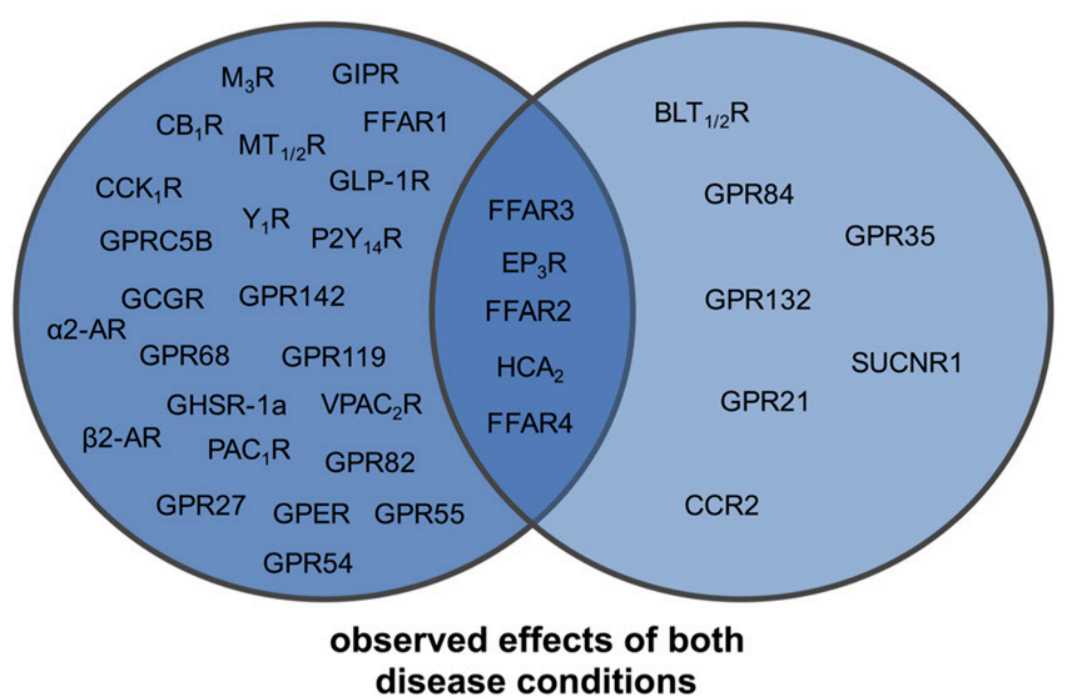

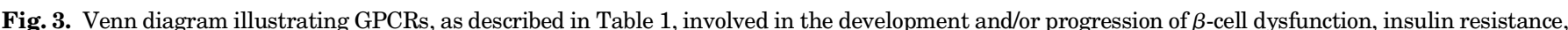

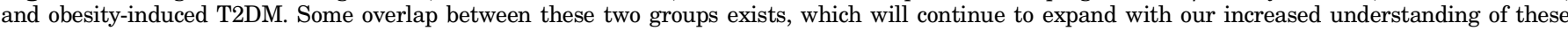
receptors and the disease pathophysiology. The number of targets illustrated perhaps reflects focus on $\beta$-cell function over the past $20-30$ years. 


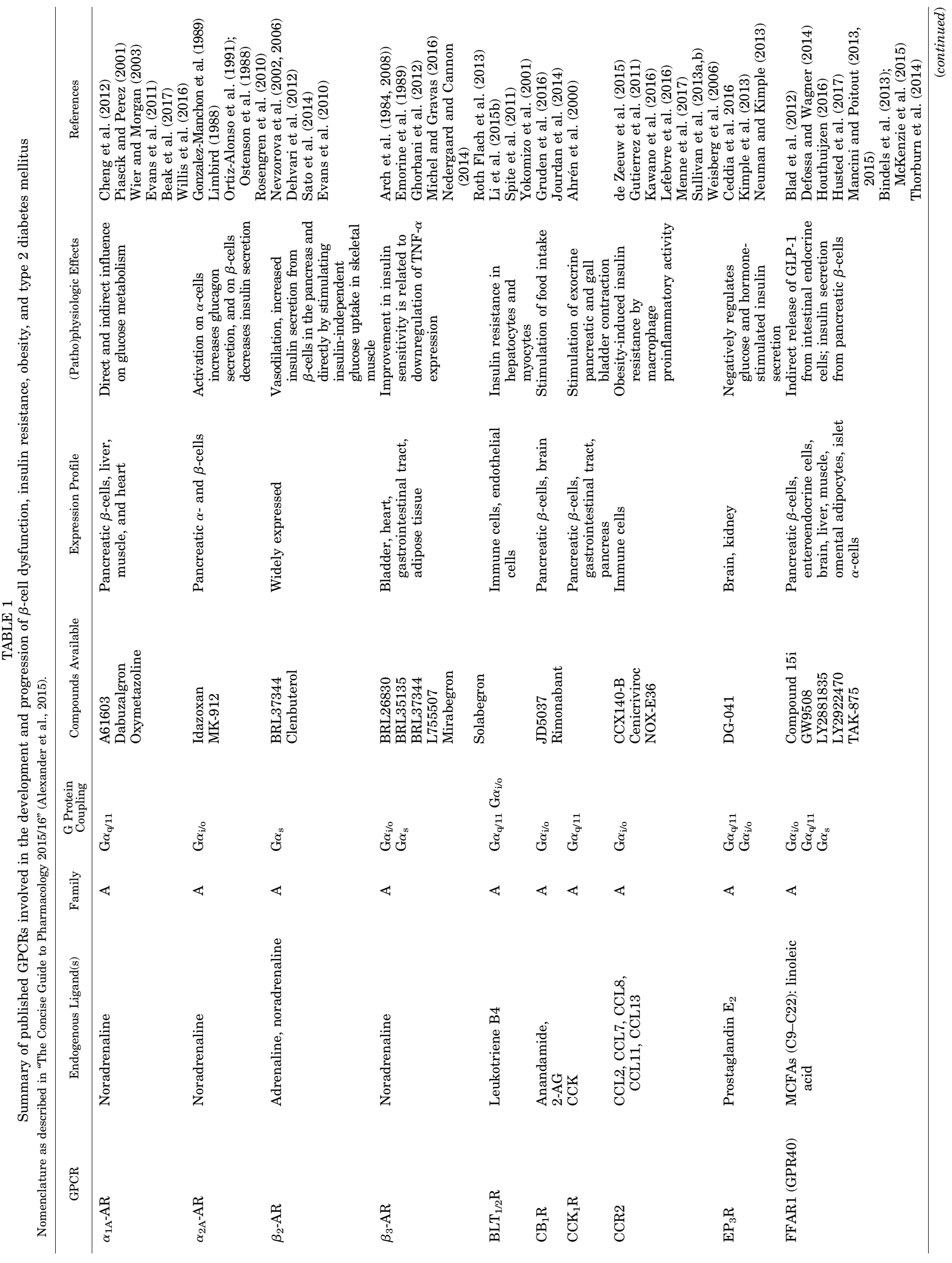




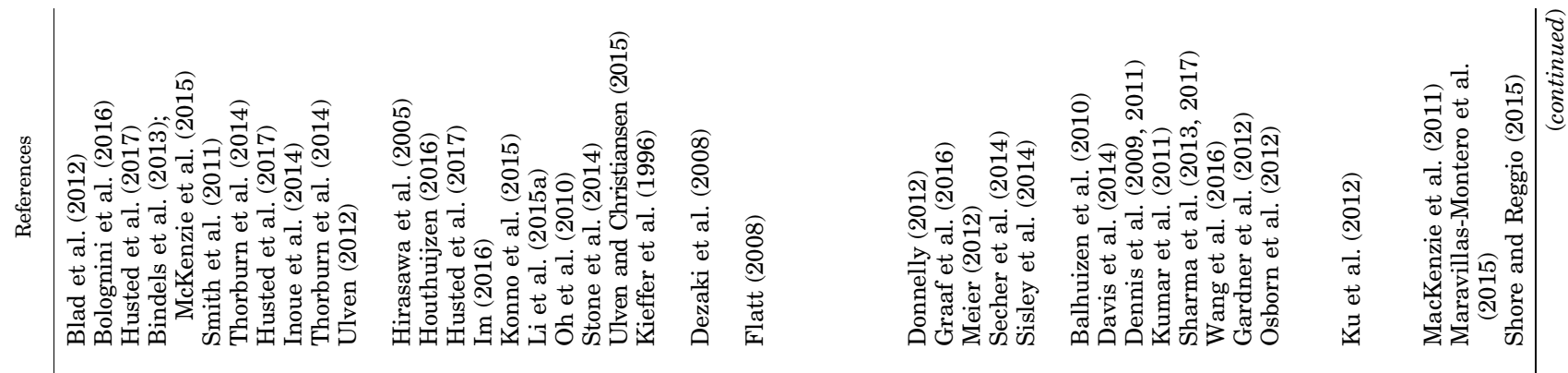

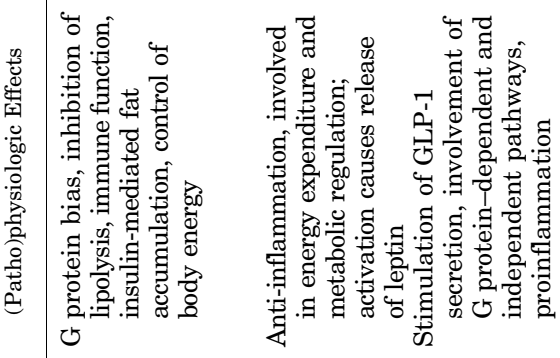
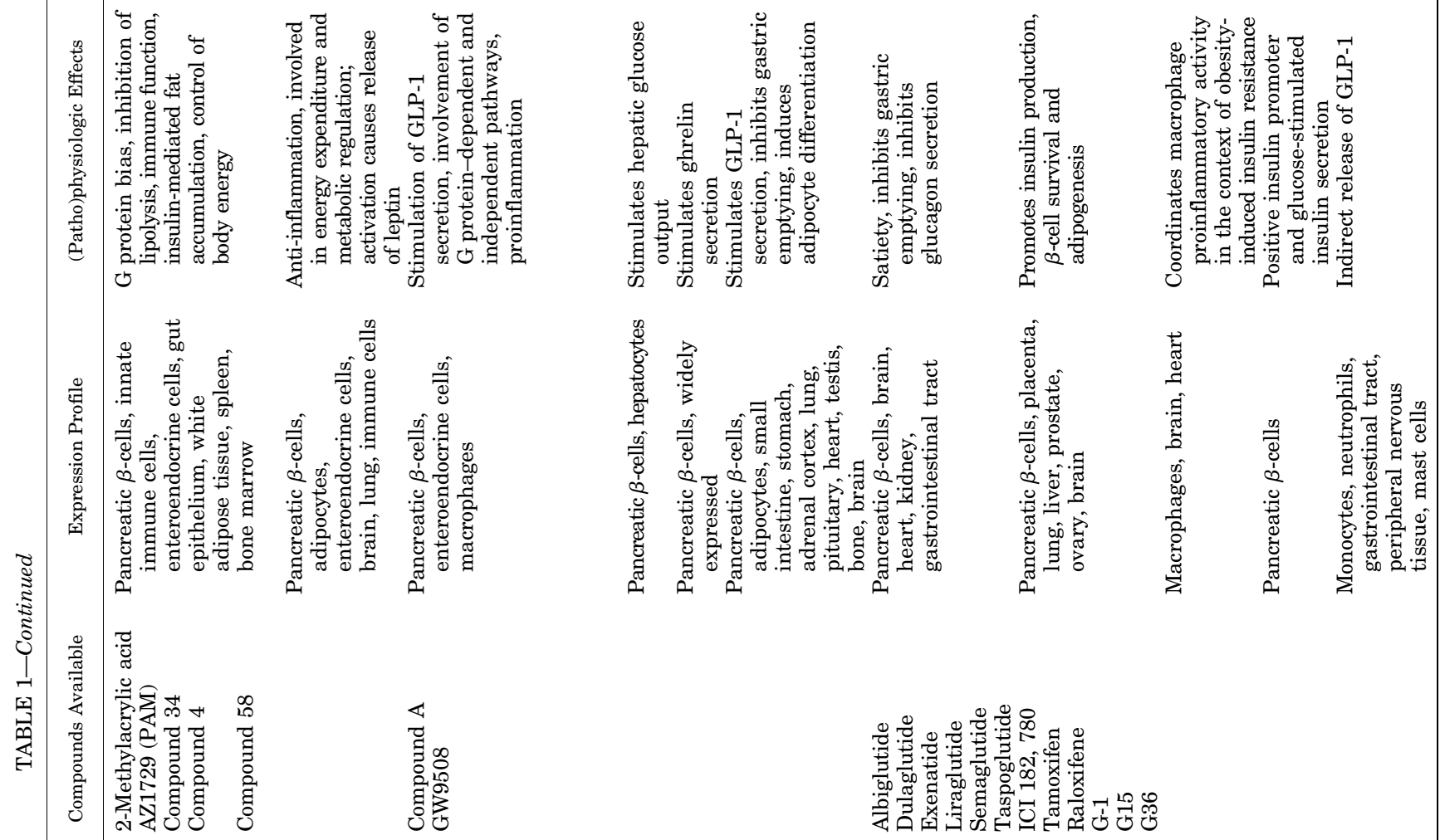

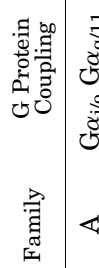
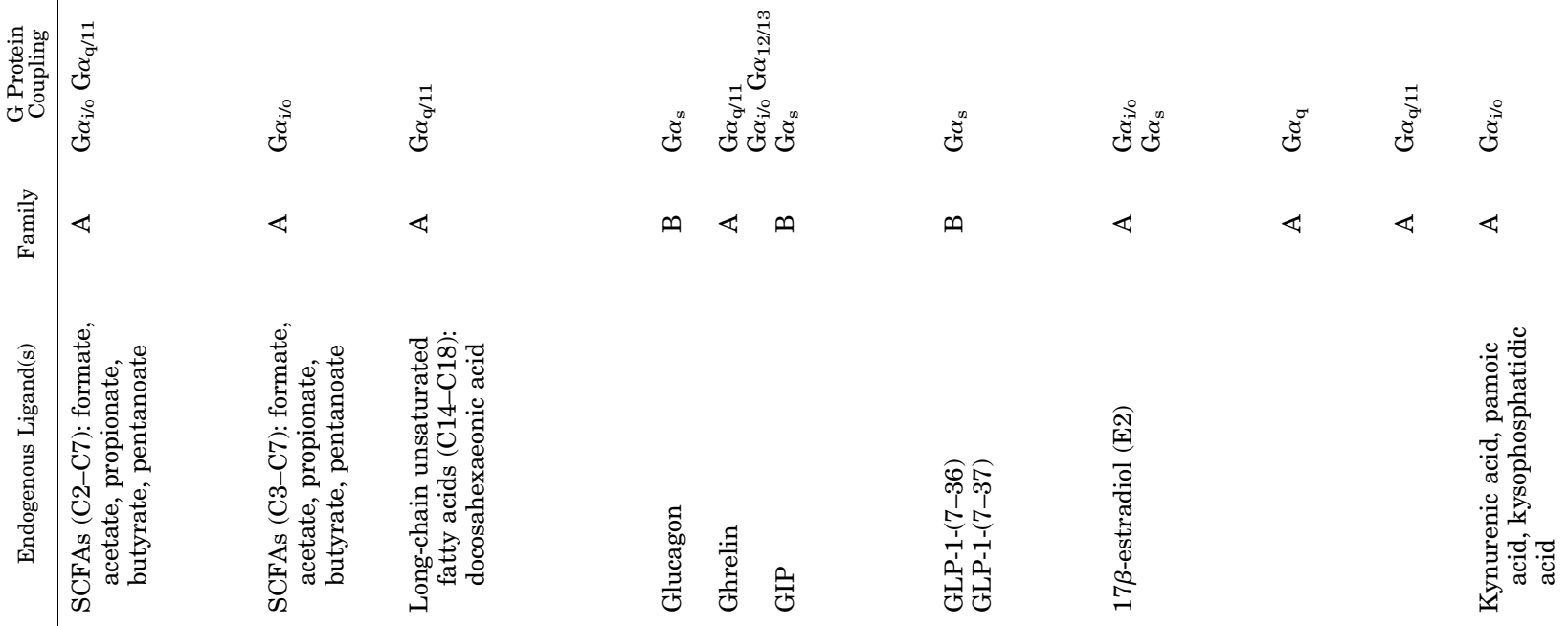

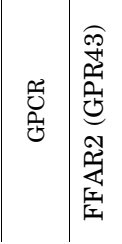

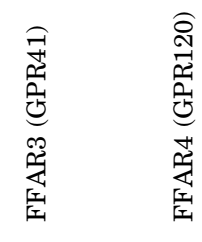

空

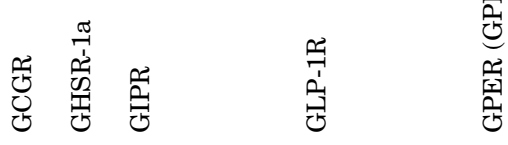

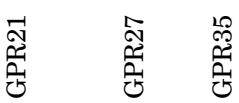




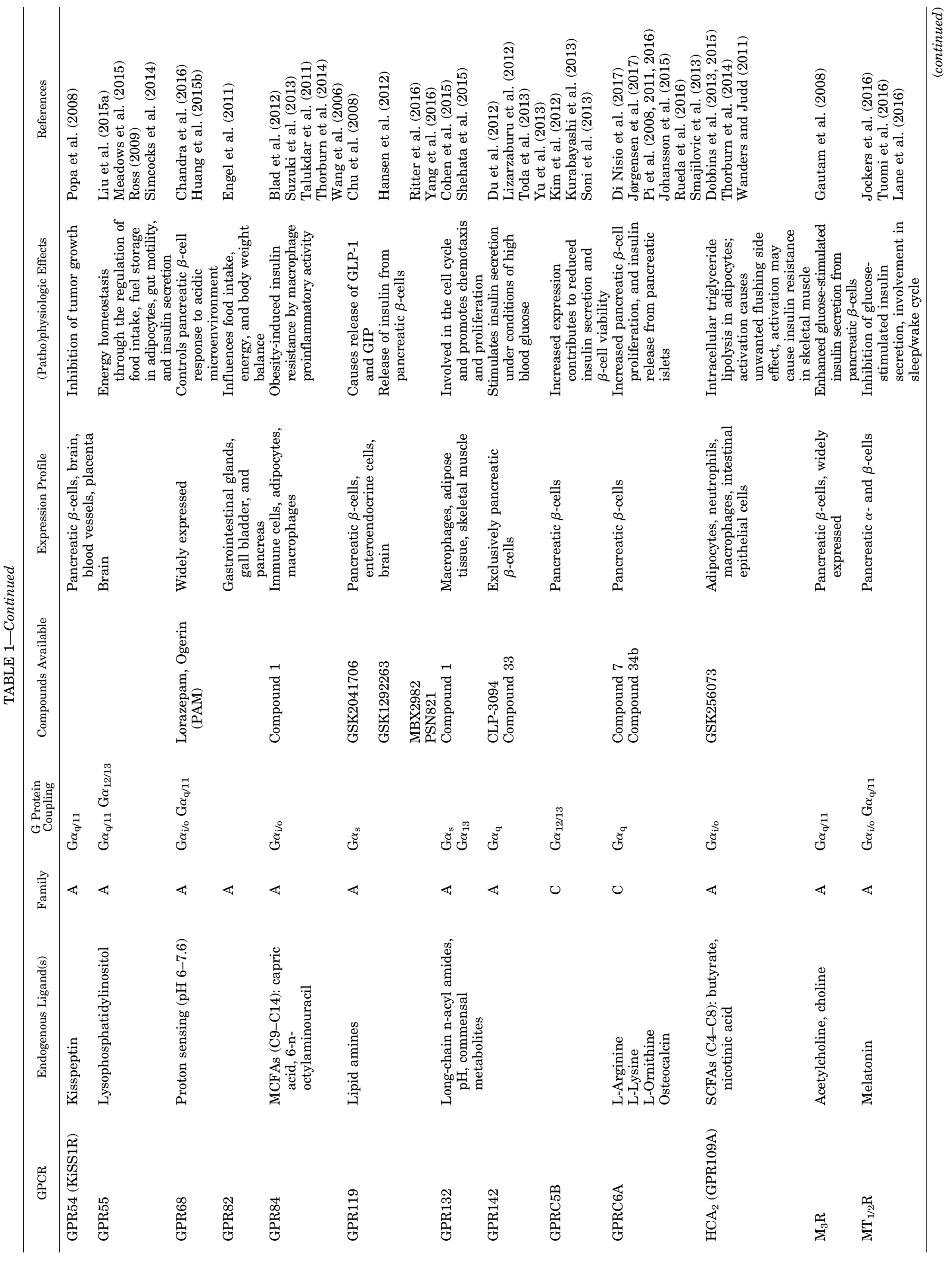




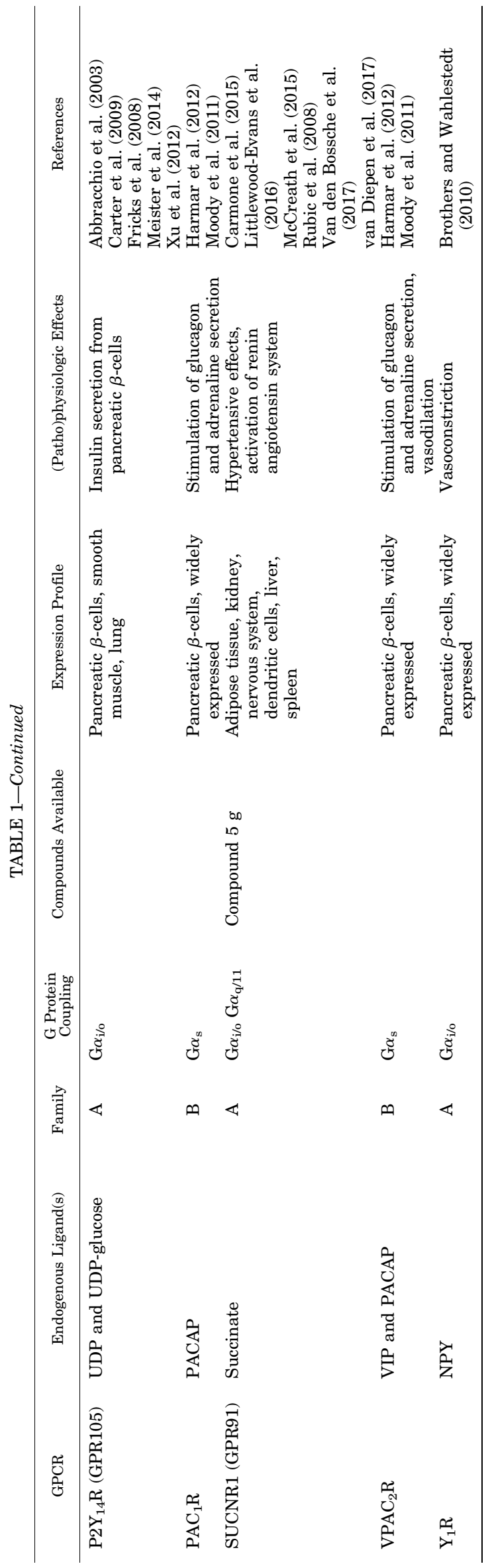

from the adrenals, and noradrenaline from sympathetic nerve endings, is one of the most efficient ways of increasing blood glucose levels. The actions of the catecholamines are mediated by a group of nine GPCRs; these adrenoceptors are divided into three subgroups, $\alpha_{1}, \alpha_{2}$, and $\beta$, based on their sequence similarities and dominant signaling pathways. The $\alpha_{1}$-adrenoceptor subgroup couples primarily to $\mathrm{G} \alpha_{\mathrm{q} / 11}$ to activate phospholipase C, causing hydrolysis of phosphatidylinositol 4,5-bisphosphate to diacylglycerol, which activates protein kinase $\mathrm{C}$ (PKC), and inositol 1,4,5-trisphosphate, which releases $\mathrm{Ca}^{2+}$, causing a variety of effects in many tissues (Piascik and Perez, 2001; Wier and Morgan, 2003); $\alpha_{2}$-adrenoceptors are $\mathrm{G} \alpha_{\mathrm{i} / \mathrm{o}}$-coupled receptors that inhibit adenylyl cyclase to reduce cAMP production, activate $\mathrm{K}^{+}$channels, and inhibit voltage-gated $\mathrm{Ca}^{2+}$ channels (Limbird, 1988); and $\beta$-adrenoceptors are $\mathrm{G} \alpha_{\mathrm{s}}$-coupled receptors that activate adenylyl cyclase to increase intracellular levels of cAMP. Each of the adrenoceptor subgroups has representatives that have a wide variety of effects on glucose metabolism; this is influenced by the receptor populations and signaling components expressed in particular cell types.

1. $\alpha_{1}$-Adrenoceptor. Activation of $\alpha_{1}$-adrenoceptors in liver, muscle, and adipose tissue has direct metabolic effects, but activation in other tissues, such as the heart, vasculature, and brain, can indirectly influence glucose metabolism. An association between the Arg347Cys polymorphism of the $\alpha_{1 \mathrm{~A}}$-adrenoceptor and severe metabolic abnormalities has been reported (Cheng et al., 2012). In skeletal muscle and adipose tissue, activation of $\alpha_{1 \mathrm{~A}}$-adrenoceptors mediates insulin-independent glucose uptake by a mechanism operating downstream of $\mathrm{Ca}^{2+}$ release and involving calmodulin-dependent protein kinase kinase and $5^{\prime}$ adenosine monophosphateactivated protein kinase (Cheng et al., 2000; Hutchinson and Bengtsson, 2006). Similar findings have been reported in response to $\alpha_{1}$-adrenoceptor agonists in human adipose tissue (Boschmann et al., 2002; Flechtner-Mors et al., 2004). Of particular interest is the evidence that $\alpha_{1 \mathrm{~A}}$-adrenoceptors are cardioprotective in heart failure. Activation of $\alpha_{1}$-adrenoceptors in the heart reduces pathologic remodelling, inhibits cell death, and improves myocyte contractility (Jensen et al., 2011; O'Connell et al., 2013; Willis et al., 2016; Beak et al., 2017) by mechanisms that include facilitation of glucose uptake (Tian and Abel, 2001; Shi et al., 2016). The role of $\alpha_{1 \mathrm{~A}^{-}}$ adrenoceptors in the failing heart is increasingly important for a number of reasons. In the normal heart, cardiac energy requirements are met primarily by ATP derived from fatty acid oxidation, but, in the failing heart, augmentation of energy production by glucose uptake becomes important for contractile function (Jaswal et al., 2011). In addition, whereas downregulation of $\beta_{1}$-adrenoceptors is a feature of heart failure, it is accompanied by upregulation of $\alpha_{1 \mathrm{~A}}$-adrenoceptors that provide an alternative insulin-independent mechanism 
for promotion of glucose uptake and improved contractile function (Shi et al., 2016). In vivo these direct effects of $\alpha_{1}$-adrenoceptor activation that promote glucose uptake into tissues may be offset by vasoconstriction that reduces blood flow and glucose uptake and by gluconeogenesis and glycogenolysis in the liver. Nevertheless, $\alpha_{1 \mathrm{~A}}$-adrenoceptors remain a potential target of interest for the treatment of metabolic disease with the discovery of biased agonism that may identify agonists that enhance glucose uptake without unwanted effects in the liver and on the vasculature (Evans et al., 2011).

2. $\alpha_{2}$-Adrenoceptor. The metabolic effect of activation of $\alpha_{2}$-adrenoceptors is mainly on the pancreas, adipose tissue, and the adrenals. $\alpha_{2 \mathrm{~A}}$-Adrenoceptors are present on both $\alpha$ - and $\beta$-cells of pancreatic islets, and activation on $\alpha$-cells increases glucagon secretion and on $\beta$-cells decreases insulin secretion. Interestingly, there is a genetic association between $\alpha_{2 \mathrm{~A}}$-adrenoceptors and T2DM. In Goto-Kakizaki rats (model of T2DM), there is a locus containing Adra2a that was associated with a reduction in glucose-stimulated insulin secretion and a marked increase in $\alpha_{2 \mathrm{~A}}$-adrenoceptors in $\beta$-cells (Rosengren et al., 2010). The authors went on to examine whether single-nucleotide polymorphisms associated with ADRA2A in humans were associated with these traits and with T2DM. They found an association for one single-nucleotide polymorphism rs553668 that displayed reduced insulin secretion and an increased risk of T2DM. However, it has also been pointed out that the contribution of this mutation to overall T2DM is likely to be very small in line with the condition being polygenic and greatly influenced by lifestyle factors (Liggett, 2009). $\alpha_{2 \mathrm{~A}}$-Adrenoceptors also decrease lipolysis in adipocytes, suggesting that agonists would decrease glycerol available for hepatic gluconeogenesis (Gonzalez-Manchon et al., 1989). It has been suggested that $\alpha_{2}$-adrenoceptor antagonists may provide a mechanism to improve insulin secretion and glucose tolerance, but studies in humans have been equivocal (Ostenson et al., 1988; Ortiz-Alonso et al., 1991).

3. $\beta_{2}$-Adrenoceptor. $\beta_{2}$-Adrenoceptors are the most widely distributed of the $\beta$-adrenoceptor subgroup and are expressed in skeletal muscle, cardiac muscle, and blood vessels, as well as liver, pancreas, and adipose tissue. Physiologic activation of $\beta_{2}$-adrenoceptors is mainly by adrenaline that is about two orders of magnitude more potent than noradrenaline at this receptor. Activation can lead to increased glucose uptake by a number of mechanisms-indirectly by vasodilation and by increasing insulin secretion from $\beta$-cells in the pancreas and directly by stimulating insulin-independent glucose uptake in skeletal muscle (Nevzorova et al., 2002, 2006). In the liver, stimulation of $\beta_{2}$-adrenoceptors causes glycogenolysis (Chu et al., 2000) and a significant increase in blood glucose levels. However, in skeletal muscle, activation of $\beta_{2}$-adrenoceptors causes an increase in glucose uptake involving cAMP (Nevzorova et al., 2002, 2006), G protein receptor kinase (Dehvari et al., 2012), activation of mTORC2, and translocation of GLUT4 to the cell surface (Sato et al., 2014). The translocation of GLUT4 to the cell surface following $\beta_{2}$-adrenoceptor activation does not involve either Akt or AS160 as required by insulin (Sato et al., 2014). Administration of the long-acting $\beta_{2}$-adrenoceptor agonist clenbuterol to Goto-Kakizaki rats or obese C57BL/6J mice improves glucose tolerance (Sato et al., 2014). However, in addition, in adipose tissue there is increased lipolysis, and in a number of tissues including muscle and adipose tissue, $\beta_{2}$-adrenoceptor activation inhibits insulin-mediated glucose uptake (Hunt et al., 2002; Eriksson et al., 2004). Because ligand-directed signaling bias is also a feature of $\beta_{2}$-adrenoceptor signaling, it may be possible to develop therapies to lower blood glucose by actions on muscle without promoting glycogenolysis in the liver (Evans et al., 2010).

4. $\beta_{3}$-Adrenoceptor. The $\beta_{3}$-adrenoceptor has long been a potential target for the development of antiobesity drugs. Even before the $\beta_{3}$-adrenoceptor was cloned (Emorine et al., 1989), atypical $\beta$-adrenoceptor agonists had been developed that selectively stimulated lipolysis in brown adipocytes (Arch et al., 1984), an effect later shown to be mediated by $\beta_{3}$-adrenoceptors. mRNA encoding $\beta_{3}$-adrenoceptors is found in the bladder, heart, gastrointestinal tract, and adipose tissue, with particularly high concentrations in rodent brown fat (Evans et al., 1996, 1999; Emilsson et al., 1998). Although several studies have examined effects of $\beta_{3^{-}}$adrenoceptor agonists on lipolysis and heat production in brown fat, it was apparent even in early studies that $\beta_{3}$-adrenoceptor (or atypical $\beta$-adrenoceptor) agonists improve glucose tolerance and insulin sensitivity (Cawthorne et al., 1984; Sennitt et al., 1985; Williams et al., 1999). Recent studies suggest that the improvement in insulin sensitivity is related to downregulation of TNF- $\alpha$ expression (Ghorbani et al., 2012). In contrast, it has been shown that $\beta_{3}$-adrenoceptor activation upregulates E-selectin to induce neutrophil infiltration and inflammation in adipose tissue (Roth Flach et al., 2013). Unfortunately, further development of the $\beta_{3}$-adrenoceptor as a therapeutic target stopped when it was discovered that the $\beta_{3}$-adrenoceptor agonists BRL26830, BRL37344, and BRL35135, developed on the basis of their actions on rodent brown fat, had much lower efficacy in humans. In addition, it became widely accepted that adult humans possessed little brown fat. Although subsequent studies have revealed that brown fat in humans is present and activated by cold (Nedergaard et al., 2007; Nedergaard and Cannon, 2014), there is some doubt as to whether metabolic effects on brown fat in humans are mediated by $\beta_{3^{-}}$ adrenoceptors (Arch, 2008). The recent introduction of the human selective $\beta_{3}$-adrenoceptor agonists mirabegron and solabegron for the treatment of overactive 
bladder (Michel and Gravas, 2016) may allow the reinvestigation of the metabolic effects of $\beta_{3}$-adrenoceptor agonists (Arch, 2002).

\section{B. $C B_{1} R$}

Cannabinoid receptors are highly expressed in the CNS and on immune and inflammatory cells. There are two cannabinoid receptors, $\mathrm{CB}_{1} \mathrm{R}$ and $\mathrm{CB}_{2} \mathrm{R}$, which are activated by the bioactive lipid molecules anandamide and 2-arachidonoylglycerol. Activation of $\mathrm{CB}_{1} \mathrm{R}$ in the CNS causes an increased food intake that is further enhanced by the mesolimbic system. However, activation of $\mathrm{CB}_{1} \mathrm{R}$ in metabolic tissues, including both white and brown adipocytes, causes an increase in fatty acid synthesis and reduction in lipolysis (Gruden et al., 2016); in Zucker diabetic fatty rats, overstimulation of $\mathrm{CB}_{1} \mathrm{R}$ expressed on macrophages caused a marked increase in the activation of the inflammasome, apoptosis, and loss of $\beta$-cell function (Rohrbach et al., 2012). More recently, increased activation and signaling of the $\mathrm{CB}_{1} \mathrm{R}$ in podocytes have been implicated in the development of type 2 diabetic nephropathy (Jourdan et al., 2014). Multiple studies have shown an improvement in metabolic phenotype when treated with $\mathrm{CB}_{1} \mathrm{R}$ antagonists, including SR141716 (Rimonabant; SanofiAventis, Paris, France) (Lafontan et al., 2007; Scheen, 2007; Nam et al., 2012). However, development of suitable therapeutics has proved challenging due to on-target neuropsychiatric effects. To overcome this, antagonists, such as JD5037, have been developed that do not penetrate the brain and improve pancreatic $\beta$-cell function and decrease cell loss in animal models (Chorvat, 2013; Jourdan et al., 2014); however, no human studies with this compound have yet been initiated. For a comprehensive review on the endocannabinoid system, see Gruden et al. (2016).

\section{C. $E P_{3} R$}

Prostaglandin $\mathrm{E}_{2}$ is derived from arachidonic acid and is the endogenous ligand for the $\mathrm{EP}_{3} \mathrm{R}$. In the $\mathrm{BTBR}$ mouse strain, containing the leptin ${ }^{o b / o b}$ mutation to cause obesity and diabetes, the $\mathrm{EP}_{3} \mathrm{R}$ negatively regulates insulin secretion, and upregulation of both the ligand and receptor inhibits GLP-1R signaling (Neuman and Kimple, 2013). In a recent study by Neuman et al. (2017), enrichment of pancreatic islets with eicosapentaenoic acid, the precursor to prostaglandin $E_{3}$, caused a marked decrease in arachidonic acid, improved glucose-stimulated insulin secretion, a reduction in IL- $1 \beta$ production, and an improvement in glucose tolerance and $\beta$-cell function. Thus, blockade of $\mathrm{EP}_{3} \mathrm{R}$ in pancreatic islets may be a viable therapy and recently new $\mathrm{EP}_{3} \mathrm{R}$ antagonists have been disclosed (Abdel-Magid, 2015). However, data from Vanderbilt University (Nashville, TN) researchers have shown conflicting data. Ep3r ${ }^{-1-}$ mice, generated on the C57BL/6 background and fed a high-fat diet, displayed an increase in macrophage infiltration, increased ectopic lipid accumulation in skeletal muscle and liver, and hepatic steatohepatitis, culminating in increased obesity, lipolysis, and increased insulin resistance (Ceddia et al., 2016). These discrepancies highlight the need for further investigation into $\mathrm{EP}_{3} \mathrm{R}$ as a metabolic target and emphasize the context dependency of data between different animal models.

\section{Free Fatty Acid Receptors: FFAR1, FFAR2, and FFAR3 (GPR40, GPR43, and GPR41)}

The benefits of dietary fiber have been recognized for decades, although the identification of the targets involved in these effects has only recently been established (Thorburn et al., 2014; Alvarez-Curto and Milligan, 2016). FFA receptor (FFAR)1, FFAR2, and FFAR3 bind short-chain fatty acids (SCFAs), including acetate, propionate, and butyrate, produced from the fermentation of undigested carbohydrates and dietary fibers by colonic bacteria (Bindels et al., 2013; McKenzie et al., 2015), and have subsequently been termed metabolite-sensing GPCRs. SCFAs produce many beneficial effects, including maintenance of immune and gut homeostasis, regulation of $T$ cell activation, and control of various immune pathways, specifically via the inhibition of NF- $\kappa \mathrm{B}$ signaling (Thorburn et al., 2014). Each receptor is widely expressed in multiple metabolically important tissues, including pancreatic $\beta$-cells, immune cells, adipocytes, and enteroendocrine cells (Table 1); for comprehensive reviews, see Blad et al. (2012), Husted et al. (2017), and Milligan et al. (2017).

1. FFAR1. FFAR1 is a target of great therapeutic interest after the phase II clinical trial with fasiglifam (TAK-875), a FFAR1 agonist, yielded lowering of HbA1c without unwanted side effects, including hypoglycemia or tachyphylaxis (Burant, 2013). In animal models of T2DM, FFAR1 agonists increase levels of insulin secretion and may indirectly release GLP-1 from intestinal endocrine cells (Defossa and Wagner, 2014). FFAR1 appears to couple exclusively to $\mathrm{G} \alpha_{\mathrm{q} / 11}$ proteins to produce an increase in cytosolic $\mathrm{Ca}^{2+}$ concentration, phospholipase C activation (Ahrén, 2009), and insulin secretion.

Perhaps surprisingly, fasiglifam acts allosterically at a secondary binding site, distinct to that used by the endogenous SCFA ligands (Lin et al., 2012), and was recently used to facilitate solution of the crystal structure of FFAR1 (Srivastava et al., 2014). Interestingly, the structure revealed a unique binding mode in which fasiglifam appears to access the allosteric binding pocket in the lipid bilayer. These data corroborate the allosteric mechanism identified from traditional binding studies and functional assays. One issue surrounding FFAR 1 is the potential link with glucolipotoxicity by chronically elevated SCFA levels, which promotes $\beta$-cell dysfunction (Mancini and Poitout, 2013). Although most studies using FFAR1 agonists demonstrate an 
improvement in glycemic control, further studies are required to ascertain whether long-term use has detrimental consequences. The recent phase III trial of fasiglifam was terminated due to high levels of hepatotoxicity caused by off-target inhibition of hepatobiliary transporters, including the efflux transporter (multidrug resistanceassociated protein 2), and the uptake transporter (organic anion-transporting polypeptide) (Li et al., 2015c).

Encouragingly, new FFAR1 agonists developed by Eli Lilly, including LY2881835 and LY2922470, are in phase I and reduce hyperglycemia and increase GLP-1 secretion in both rats and humans (Mittermayer et al., 2015; Hamdouchi et al., 2016), suggesting that these compounds may still prove beneficial for the treatment of T2DM.

2. FFAR2. FFAR2 was deorphanized in 2003 (Brown et al., 2003); it is activated by SCFAs, including propionate and butyrate (Bindels et al., 2013), and pleiotropically couples to at least $\mathrm{G} \alpha_{\mathrm{i}}$ and $\mathrm{G} \alpha_{\mathrm{q}}$. Interestingly, activation of these signaling pathways causes opposing effects. $\mathrm{G} \alpha_{\mathrm{i}}$ inhibits glucose-stimulated insulin secretion, whereas $\mathrm{G} \alpha_{\mathrm{q}}$ increases glucosestimulated insulin secretion (McKenzie et al., 2015). The existence of signaling bias as well as multiple endogenous SCFA ligands provides both additional layers of complexity and therapeutic opportunities for targeting FFAR2. Due to the close homology between FFAR2 and FFAR3, identification of selective ligands has been important for greater understanding of the signaling and pharmacology of these receptors. Three key amino acids, E166, L183, and C184, within the orthosteric binding pocket, govern the selectivity between FFAR2 and FFAR3 for metabolite binding (Schmidt et al., 2011). Multiple compounds that bind to either the orthosteric or allosteric binding pocket have now been discovered (Lee et al., 2008; Milligan et al., 2009; Bindels et al., 2013). Recently, AZ1729 was shown to display novel allosteric $\mathrm{G} \alpha_{\mathrm{i}}$ signaling bias in mouse colonic preparations and human neutrophils (Bolognini et al., 2016).

It has been suggested that there is a link between FFAR2 and/or FFAR1 (Wang et al., 2015) and the peroxisome proliferator-activated receptor $\gamma$, an established target for the glitazones currently used as a treatment of T2DM. In mouse 3T3-L1 cells, a reduction in Ffar2 expression with small infering RNA (siRNA), or addition of a peroxisome proliferator-activated receptor $\gamma$ agonist, produced changes in expression of both receptors. However, Bindels et al., (2013) recently showed that this effect does not translate from mouse to human. Ffar $2^{-1-}$ mice also display contradictory phenotypes, in which in one study an increase in energy expenditure and a decrease in body mass were observed (Bjursell et al., 2011), whereas in a second study, using the knockout (KO) animals on the same background, an increase in body mass of mice fed either normal chow or a high-fat diet was found, and the mice did not display phenotypic differences in glucose homeostasis or insulin resistance (Kimura et al., 2013).

Activation of FFAR2 by SCFA also causes the recruitment and migration of neutrophils. Changes in the migratory ability of these cells during inflammation may contribute to the pathophysiology of T2DM (Sina et al., 2009; Vinolo et al., 2011; Corrêa-Oliveira et al., 2016). Although FFAR2 appears to be an attractive target, further investigation into its signaling profile, development of compounds that display similar affinities in both rodent and human recombinant systems, and confirmation of the effects observed in $\mathrm{KO}$ mouse studies in human samples and patients will be necessary.

3. FFAR3. As described above, there is close homology between FFAR2 and FFAR3, and therefore, FFAR3 is activated by similar SCFAs, including formate, acetate, propionate, and butyrate (Ulven, 2012), although the rank orders differ between the receptors. Development of synthetic compounds for FFAR3 has been slow, with only a handful of compounds identified to date. These include both orthosteric and allosteric compounds (Milligan et al., 2017). One such allosteric compound is AR420626 (Arena Pharmaceuticals), which caused GLP-1 release from mouse colonic crypt cells (Nøhr et al., 2013). However, the poor potency of this, and other identified allosteric compounds, limits their suitability for in vivo studies.

FFAR3 has been shown to be involved in energy expenditure and metabolic regulation, although, unlike FFAR1 and FFAR2, most data have been obtained from KO mouse studies (for a comprehensive review, see Ulven, 2012 and Tang et al., 2015). Controversy exists as to whether FFAR3 is expressed in adipose tissue and if its activation causes the release of leptin, or whether another receptor, possibly FFAR2, is involved (Inoue et al., 2014), suggesting that KO of both FFAR2 and FFAR3 is required to identify any specific effects (Tang et al., 2015). Little is known of the signaling pathways involved in energy homeostasis by FFAR3 (Inoue et al., 2014). Although modulation of FFAR3 appears to warrant further investigation, no progress can be made until more potent and selective compounds are developed.

\section{E. Glucagon-Like Peptide 1 Receptor}

GLP-1 is a key incretin, promoting glucose-dependent insulin secretion in response to meal ingestion. It has broad physiologic effects, including preservation of $\beta$-cell mass, and inhibition of glucagon secretion, gastric emptying, and food intake, in addition to its incretin role (Baggio and Drucker, 2014; Graaf et al., 2016). GLP-1 is also cardio- and neuroprotective (Salcedo et al., 2012; Graaf et al., 2016; Wiberg et al., 2016). Endogenous GLP-1 is rapidly degraded by endopeptidases, most prominently dipeptidyl peptidase-IV (DPP-IV), and has a very short plasma half-life, making it unsuitable as a therapeutic. 
As such, targeting of the GLP-1R has focused on peptide mimetics resistant to enzymatic degradation, and with prolonged plasma half-life (Hui et al., 2002). These peptide agonist mimetics lower $\mathrm{HbA} 1 \mathrm{c}$ in $\mathrm{T} 2 \mathrm{DM}$, acting both directly on the pancreatic $\beta$-cell and via vagal afferents (Trujillo et al., 2015; Krieger et al., 2016). In addition, GLP-1R agonists cause increased $\beta$-cell proliferation, regeneration, and neogenesis, in both animal models and in vitro cultures of human islets (Tian et al., 2011), and decreased apoptosis (Vilsbøll, 2009), collectively contributing to preservation of $\beta$-cell mass. However, these effects may be specific to mouse models. There are now multiple GLP-1R agonists approved for T2DM treatment, including exenatide, albiglutide, and liraglutide (reviewed in detail; Meier 2012; Graaf et al., 2016).

Importantly, long-term treatment with GLP-1R agonists promotes satiety and weight loss in both diabetic and obese patients (van Bloemendaal et al., 2014). GLP$1 \mathrm{R}$ is expressed on the vagus nerve, linking the gut to the CNS, and abundantly in the hypothalamus, paraventricular nucleus, dorsomedial nucleus, and arcuate nucleus (Baggio and Drucker, 2014). The weight loss is most likely driven by combination of GLP-1 action to inhibit gastric emptying, as well as direct actions in the CNS; direct activation of propiomelanocortin expressing arcuate nucleus neurons by liraglutide induced weight loss, which was blocked by the GLP-1R antagonist exendin (9-39) (Secher et al., 2014; Sisley et al., 2014). Nonetheless, KO of GLP-1R in the CNS using nestin-Cre Glp1r ${ }^{f l / f l}$ mice, or vagus nerve using Phox $2 b$ Cre Glp1r ${ }^{f l / f l}$ mice, did not affect food intake or body weight of animals fed normal chow or a high-fat diet, suggesting that activation of receptors at either site alone may have limited benefit. Beneficial weight loss is well-documented for treatment with exenatide and liraglutide (Raun et al., 2007; Buse et al., 2009), the earliest drugs to market; liraglutide has also been approved independently for treatment of obesity in the United States (Iepsen et al., 2015). These initial drugs are metabolically stable peptide mimetics of GLP-1 that require daily injections, and much recent work has focused on development of drugs with extended halflives, including sustained release formulation (taspoglutide), albumin fusion (albiglutide), and linkage to modified Fc of immunoglobulin (dulaglutide), for onceweekly injection (Smith et al., 2016). Overall, GLP-1 mimetics have an excellent safety profile; the most prevalent side effects include injection-site reactions, nausea, diarrhea, or vomiting, and these effects can be dose limiting in patients. The latter events are thought to be primarily related to effects on the gastrointestinal tract; however, these tend to abate with time (Buse et al., 2009). Of note, taspoglutide was withdrawn from phase III clinical trials due to high risk for nausea (Zaccardi et al., 2016). All approved mimetics improve $\mathrm{HbA1c}$ levels, although the longer-acting formulations appear to have reduced efficacy for control of body weight, with limited effect on gastric emptying (Dungan et al., 2014; Pratley et al., 2014). A new generation mimetic with reversible albumin binding, semaglutide, formulated for once-weekly dosing, has shown promising effects on HbA1c and body weight control (Blundell et al., 2017), whereas implantable technologies for osmotic slow release (Intarcia) are currently in phase III clinical trials for delivery of exenatide over a 6-month period. Evidence is now emerging that liraglutide (Velez et al., 2015) and semaglutide may also have beneficial effects with respect to cardiovascular function and mortality (Marso et al., 2016), increasing the potential benefit of this drug class for treatment of T2DM patients at risk for cardiovascular disease.

There is increasing interest in benefits of dualspecificity peptide ligands that have activity at multiple glucagon-peptide family receptors, combining activity at GLP-1 and glucagon receptors (Day et al., 2009), or GLP-1 and GIP receptors (De and DiMarchi, 2010); these peptide agonists have shown promise in preclinical studies for obesity treatment with greater weight loss than seen with GLP-1 agonism alone (Day et al., 2009; De and DiMarchi, 2010). This dual targeting strategy is being pursued by companies, including Zealand Pharma and Transition Therapeutics. Moreover, combination of GLP-1 agonists with other anorectic peptides such as amylin is reported to provide synergistic effects on weight loss (Roth et al., 2012).

The GLP-1 receptor has been refractory to smallmolecule drug development, and this may in part be explained by the extended pharmacophore recently revealed by structural studies (Jazayeri et al., 2017; Song et al., 2017; Zhang et al., 2017), which would create difficulties for development of mimetics acting via the orthosteric peptide binding site. A number of smallmolecule compounds have been disclosed (Willard et al., 2012), but none have yet been developed for therapeutic use. Many of these act as allosteric ligands, and indeed, at least one class acts on the intracellular face of the receptor (Nolte et al., 2014). As an alternative, a range of modified peptides of $\sim 11$ amino acids has been developed, some of which retain high affinity and potency (Huang et al., 2015a; Jazayeri et al., 2017), and are resistant to degradation (Jazayeri et al., 2017). These peptides have both overlapping and unique interactions with GLP-1 at targeting GLP-1 receptors (Jazayeri et al., 2017; Zhang et al., 2017). It is believed that such peptides may be better suited for oral formulation. Nonetheless, semaglutide has been trialled in oral formulation, and, despite limited bioavailability, can still achieve therapeutically viable concentrations (Jensen et al., 2017), with high enough dose.

The GLP-1R is a secretin-like class B GPCR (Donnelly, 2012) and is pleiotropically coupled to multiple $\mathrm{G}$ proteins, including $\mathrm{G} \alpha_{\mathrm{i}}, \mathrm{G} \alpha_{\mathrm{o}}$, and $\mathrm{G} \alpha_{\mathrm{q} / 11}$, as well as other effector/regulatory proteins, most notably the arrestins (Koole et al., 2013; Graaf et al., 2016), and this 
has very broad consequences for intracellular signaling. Virtually all GLP-1 ligands that have been assessed appropriately exhibit biased agonism relative to the principal endogenous GLP-1 peptide [GLP-1(7-36) $\left(\mathrm{NH}_{2}\right)$ ] (Koole et al., 2010; Graaf et al., 2016; Wootten et al., 2017). This is evident for both natural ligands of the receptor (e.g., oxyntomodulin) and GLP-1 mimetics (e.g., exendin-4), with divergent effects of each of these peptides in pancreatic $\beta$-cell-like INS-1 insulinoma cells (Wootten et al., 2016). This is likely to impact on treatment outcomes with different GLP-1 mimetic drugs. Indeed, although principally considered in the context of altered pharmacokinetics, there are diverse outcomes observed with currently approved therapeutics for body weight, gastric emptying, and cardiovascular improvement, as well as the extent of unwanted side effects (Graaf et al., 2016) that may also arise from biased agonism of these peptides. Of particular note, a recently discovered analog of exendin-4, termed exendin-P5, which had a different signaling bias to exendin-4, displayed a distinct impact in preclinical models of diabetes and obesity (Zhang et al., 2015). Both peptides reduced plasma glucose; however, in contrast to exendin-4, exendin-P5 was only a weak insulinotrope and caused altered adiposity. Thus, altered signaling bias could provide novel therapeutic potential for this target. To date, we have only a poor understanding of which signaling pathways interplay for beneficial effects in both the pancreas and extrapancreatic tissues that control appetite, gastric emptying, and cardioand/or neuroprotection. Nonetheless, this promises to be a fruitful area of research for development of newgeneration GLP-1R drugs.

\section{F. G Protein-Coupled Estrogen Receptor}

$\mathrm{G}$ protein-coupled estrogen receptor (GPER), the nongenomic receptor for estrogen, previously denoted GPR30, is widely expressed in the heart, intestines, reproductive tissues, immune cells, and metabolic tissues, including adipose, skeletal muscle, and liver (Sharma et al., 2017). Furthermore, GPER expression has been reported on pancreatic $\beta$-cells, with expression levels notably higher in islets from both female mice and humans compared with those derived from male mice (Balhuizen et al., 2010; Kumar et al., 2011). The estrogen receptor agonist, $17 \beta$-estradiol, activates GPER with nanomolar affinity (Wang et al., 2016), and the genomic estrogen receptor modulators tamoxifen and raloxifene also have moderate GPER activity (Sharma et al., 2017). Recently, a selective GPER agonist (G-1) was identified that displays no activity at the estrogen receptors $\operatorname{ER} \alpha$ or $\operatorname{ER} \beta$ (Bologa et al., 2006), and selective GPER antagonists have also been discovered (G15 and G36) (Dennis et al., 2009, 2011). Activation of GPER by $17 \beta$-estradiol and G- 1 revealed coupling to both $\mathrm{G} \alpha_{\mathrm{s}}$ and $\mathrm{G} \alpha_{\mathrm{i}}$ proteins, yielding a net increase in both cAMP and intracellular $\mathrm{Ca}^{2+}$
(Martensson et al., 2009). More recently, data suggest that GPER can signal from the plasma membrane and also intracellular compartments, including the Golgi and ER (Otto et al., 2008; Cheng et al., 2011).

GPER KO mouse studies have yielded a range of reported metabolic outcomes. In one study, female Gper $1^{-/-}$mice fed a high-fat diet displayed reduced body weight and were protected from obesity-induced insulin resistance; however, no significant effects were observed in male animals (Wang et al., 2016). Contrary to these findings, Sharma et al., (2013) demonstrated that both female and male Gper $1^{-1-}$ mice had increased body weight compared with wild-type controls and developed insulin resistance. More subtly, Davis et al., (2014) showed that this increased body weight in females was delayed by 6 weeks in comparison with males. Female Gper $1^{-1-}$ mice aged 6 months also displayed impaired glucose tolerance, increased blood pressure, and reduced bone growth (Mårtensson et al., 2009). These disparities most likely result from different methods used to generate the transgenic animals and variations in the length of feeding, but overall they indicate that deletion of GPER results in a similar phenotype obtained from ER $\alpha$ KO models, suggesting that activation of GPER by estrogen may be necessary to maintain glucose homeostasis (Sharma et al., 2017). Although GPER remains an interesting drug target, further studies are required to understand the mechanism of GPER activation in metabolic tissues. Furthermore, confirmation of the effects observed in KO mouse studies in humans, both male and female, will be necessary. For a comprehensive review of GPER, see Sharma et al. (2017).

\section{G. GPR55}

GPR55 is activated by endocannabinoids and was initially classified as the third cannabinoid receptor (Ross, 2009). Subsequently, it has also been shown to be activated by lipids, including lysophospholipid, and L- $\alpha$ lysophosphatidylinositol (Henstridge et al., 2010). Unlike many of the GPCRs involved in insulin resistance or pancreatic $\beta$-cell dysfunction that predominantly couple to $\mathrm{G} \alpha_{\mathrm{s}}$ or $\mathrm{G} \alpha_{\mathrm{i}}$, GPR55 couples primarily to $\mathrm{G} \alpha_{\mathrm{q} / 11}$ and $\mathrm{G} \alpha_{12 / 13}$ (Ross, 2009; Simcocks et al., 2014). The glucoselowering and insulinotropic effects of a range of GPR55 agonists in vivo have been recently described, demonstrating the therapeutic potential for this target (McKillop et al., 2013). However, many of these ligands lack specificity, thus limiting conclusions from these studies. Recently, studies show that $G p r 55^{-1-}$ mice develop increased insulin resistance, adiposity, and fat mass (Meadows et al., 2015) together with a significant reduction in physical activity, even though muscle function was unaffected. These data therefore support the developmental potential of GPR55 selective agonists. For a more comprehensive review of the role of GPR55 in metabolism, see Liu et al. (2015a). 


\section{H. GPR82}

GPR82 belongs to the $\mathrm{P} \mathrm{Y}_{12}$-like family, which also contains the ADP receptor $\mathrm{P}_{2} \mathrm{Y}_{13} \mathrm{R}$, the UDP-glucose receptor $\mathrm{P} 2 \mathrm{Y}_{14} \mathrm{R}$, and the orphan receptors GPR87 and GPR171, all of which couple to $\mathrm{G} \alpha_{\mathrm{i}}$ (Cattaneo, 2015). Little else is known about the receptor, but, interestingly, Gpr82 $2^{-1-}$ mice display a lean phenotype, have decreased serum triglyceride levels, increased insulin sensitivity, and glucose tolerance when challenged with a Western diet (32.8\% sugar $21.2 \%$ raw fat) (Engel et al., 2011). Unfortunately, no further information is available regarding the physiologic role of the receptor. The lack of a synthetic or endogenous ligand has limited further studies into the receptor signaling.

\section{GPR119}

GPR119 is highly expressed on pancreatic $\beta$-cells and enteroendocrine cells (Hansen et al., 2012). Multiple endogenous ligands for the receptor have been identified with varying potencies, including oleoylethanolamide, $N$ oleyldopamine, olvanil, and 1-oleoyl-lysophosphatidylcholine (18:1-lysoPC) (Ahrén, 2009; Hansen et al., 2012; AlBarazanji et al., 2015). The steroid glycoside, gordonoside $\mathrm{F}$, from the popular herbal weight loss supplement Hoodia gordonii, activates GPR119 (Zhang et al., 2014). This plant has been used medicinally for thousands of years by Xhomani Bushmen as an anorexant (Zhang et al., 2014) without known side effects, suggesting gordonoside $\mathrm{F}$ may represent a novel class of compounds for further investigation. Like the FFARs, GPR119 causes the release of GLP-1 and GIP, upon activation from $\mathrm{L}$ and $\mathrm{K}$ cells, respectively (Chu et al., 2008; Lauffer et al., 2009). GPR119 couples to $\mathrm{G} \alpha_{\mathrm{s}}$ to increase glucose-stimulated insulin release from pancreatic $\beta$-cells via the formation of cAMP (Chu et al., 2008). GPR119 controls enteral glucose tolerance by three main complementary mechanisms: 1) direct activation of insulin secretion in islets, 2) promotion of secretion of incretins such as GLP-1 and GIP to potentiate glucosestimulated insulin secretion (Panaro et al., 2017), and 3) delay of gastric emptying via, at least in part, the enhancement of PYY action (Hansotia et al., 2007; Flock et al., 2011). The glucoregulatory properties of GPR119 led to the development of multiple synthetic agonists for the treatment of T2DM, including GSK1292263 (GSK), MBX-2982 (CymaBay Therapeutics), and PSN821 (Astellas/Prosidion) (Hansen et al., 2012; Nunez et al., 2014; Liu et al., 2015c; Mittermayer et al., 2015; Ritter et al., 2016). However, both GSK1292263 and MBX-2982 were discontinued due to lack of efficacy in phase II trials, in which neither compound improved glycemia handling. Clinical failure of these compounds has cast doubt on the utility of targeting GPR119 for the treatment of T2DM (Kang, 2013), but may in part be due to suboptimal compounds with low potencies or lack of sufficient exposure and activity to cause release of insulin and the incretins (Ritter et al., 2016), as most of the molecules assessed in clinical trials failed to trigger robust increases in gut hormones (Ritter et al., 2016). Nonetheless, GPR119 agonists may be effective when used in combination with current T2DM treatments. GSK2041706 in combination with metformin in diet-induced obese mice showed a synergistic effect to reduce body weight (AlBarazanji et al., 2015). In contrast, another GPR119 agonist, GSK1292263, in combination with metformin and sitagliptin in patients with T2DM yielded no additional improvement in glycemic control (Nunez et al., 2014). Although disappointing, this latter study was performed for only 14 days, and longer-term studies may be needed to better address these key questions. The lack of complete translation of the rodent pharmacology in type 2 patients with diabetes may also result from species-specific biology of the receptor. Of note, GPR119 has been found by single-cell RNA Seq to be highly expressed in human glucagon-producing $\alpha$-cells (10-fold higher levels than $\beta$-cells), where its function remains largely unknown (Blodgett et al., 2015). Interestingly, an unexpected role of GPR119 in the liver has been uncovered with some potential consequences for the treatment of fatty liver diseases (Yang et al., 2016). Whereas expression of GPR119 in hepatocytes has been a subject of debate (Odori et al., 2013), Yang et al. (2016) showed that hepatocytes do express GPR119 at both mRNA and protein levels in both mice and humans. Moreover, pharmacological activation of GPR119 led to a suppression of de novo lipogenesis via activation of AMP kinase and subsequent inhibition of the LXR-SREBP1c transcriptional cascade, ultimately resulting in a significant reduction of hepatic steatosis. These effects were abolished in Gpr $119^{-1-} \mathrm{KO}$ mice (Yang et al., 2016). Further studies are required to determine whether GPR119 agonists might be useful for the treatment of nonalcoholic fatty liver diseases.

\section{J. GPR142}

Numerous publications describe synthetic phenylalanine derivatives as agonists acting at GPR142 (Du et al., 2012; Lizarzaburu et al., 2012; Toda et al., 2013; Yu et al., 2013; Guo et al., 2016). All of these compounds were developed based on the understanding that the receptor is activated by tryptophan, an essential amino acid that is the biologic precursor to serotonin (Wurtman and Anton-Tay, 1969), and niacin (Ikeda et al., 1965). GPR142 is highly expressed on pancreatic $\beta$-cells and signals via $\mathrm{G} \alpha_{\mathrm{q}}$ (Wang et al., 2016a). Activation of the receptor enhances glucose-stimulated insulin release from pancreatic $\beta$-cells, but it is not known whether GPR142 has any further role beyond glycemic control. This limited effect may prevent GPR142 from being considered a suitable (or commercially viable) target for drug discovery. However, recent data suggest that serum tryptophan levels are 
increased in T2DM patients with a higher degree of insulin resistance (Chen et al., 2016), suggesting that inhibition of the receptor could prove beneficial. Furthermore, Gpr $142^{-1-}$ mice display reduced levels of sensitivity to a collagen antibody-induced arthritis model of inflammation (Murakoshi et al., 2016). A similar effect was observed with a GPR142 antagonist (CLP-3094) (Murakoshi et al., 2016). Identification of better tool compounds will enable greater target validation and clarification of the pathophysiological processes controlled by GPR142.

\section{K. GPRC5B}

GPRC5B is a class C GPCR that was first cloned as a retinoic acid-inducible orphan receptor (Robbins et al., 2000); its ligand, if any, remains unknown. GPRC5B is widely expressed across different tissues at the level of mRNA, with highest levels in the CNS and lowest in liver and bone marrow (Regard et al., 2008). Although relatively little is known about the function of receptor, evidence has emerged that GPRC5B plays roles in different tissues relevant to metabolic function. GPRC5B expressed in pancreatic islets negatively regulates insulin secretion, potentially by reducing cell viability, as shown by cytokine challenge in murine insulin-secreting MIN6 cells (Soni et al., 2013). Control of $G p r c 5 b$ expression is thought to skew macrophage populations to the M2, anti-inflammatory phenotype (Hohenhaus et al., 2013), and a copy number variant very close to Gprc5b has been shown to be associated with body mass index (Speliotes et al., 2010). Following this latter report, Gprc5b deficiency was found to protect mice from diet-induced obesity and insulin resistance and was associated with abolition of GPRC5B-dependent inflammation in white adipose tissue (Kim et al., 2012). GPRC5B interacts with and regulates Fyn kinase, which in turn controls proinflammatory IKK $-\varepsilon-\mathrm{NF}-\kappa \mathrm{B}$ signaling. These data converge to suggest that an antagonist of GPRC5B could be effective to reduce pathophysiology and symptomology of metabolic syndrome at a number of levels. However, to date, no known small-molecule ligands of the receptor have been discovered.

\section{GPRC6A}

GPRC6A is a class C GPCR that has been cloned from human, mouse, rat, goldfish, and bonobo chimpanzee. The receptor mediates responses to basic L-amino acids, such as arginine, ornithine, and lysine, which bind in the N-terminal (Venus flytrap) domain of the receptor (Wellendorph and Bräuner-Osborne, 2009) in a manner analogous to the binding of L-glutamate to metabotropic glutamate receptors.

In line with its amino acid pharmacology, GPRC6A was originally thought of as a nutrient-sensing receptor. Recent studies suggest that GPRC6A is involved in an array of metabolic, endocrine, and inflammatory processes (Pi et al., 2008, 2011, 2012; Wellendorph et al., 2009; Rossol et al., 2012; Clemmensen et al., 2013a,b; Smajilovic et al., 2013), although the evidence is equivocal. One $G p r c 6 a^{-1-}$ mouse strain displays manifestations of metabolic syndrome, with increased fasted plasma glucose levels and impaired insulin sensitivity (Pi et al., 2008), and a polymorphism in the Gprc6a gene that is associated with insulin resistance in normal weight and obese subjects has been identified (Di Nisio et al., 2017). However, a different KO mouse strain has a much less pronounced phenotype, with no evidence of disrupted glucose handling or insulin sensitivity, and impairments in glucose metabolism only observed when the mice were fed a high-fat diet (Smajilovic et al., 2013).

Perhaps the biggest area of contention with respect to GPRC6A and metabolic disorders has been the enigmatic role of the bone-derived peptide, osteocalcin $(\mathrm{OCN})$. The decarboxylated form of this osteoblastderived protein exerts a number of beneficial metabolic and endocrine effects, including control of energy expenditure regulated by the pancreas (Lee et al., 2007); $\mathrm{Ocn}^{-1-}$ mice display reduced pancreatic cell proliferation, impaired glucose handling, and insulin resistance. Furthermore, systemic administration of OCN increases circulating insulin levels in wild-type but not Fprc6a $^{-1-}$ mice (Pi et al., 2011). OCN has also been shown to increase pancreatic $\beta$-cell proliferation, insulin release from pancreatic islets, insulin sensitivity, energy expenditure, and testosterone synthesis in the gonads in mice (Lee et al., 2007; Oury et al., 2011). Furthermore, OCN-mediated insulin and GLP-1 release have also been reported in immortalized pancreatic $\beta$-cell lines, effects that are blocked by siRNA targeting Gprc6a (Pi et al., 2011; Mizokami et al., 2013). However, a recent study suggests that OCN does not increase GLP-1 release from enteroendocrine cells or insulin release from islets or immortalized $\beta$-cells (Rueda et al., 2016), adding further intrigue to the biology.

The positive effects of OCN, combined with the lack of OCN efficacy in $G p r c 6 a^{-1-}$ mice, both in vivo and ex vivo, have led to suggestions that decarboxylated OCN acts directly via GPRC6A to exert its metabolic and endocrine effects. Despite this evidence, verification of a direct action of decarboxylated OCN on GPRC6A has proven somewhat elusive. Several reports have shown that OCN stimulates cAMP accumulation or extracellular signal-regulated kinase 1/2 phosphorylation in HEK293 cells recombinantly expressing GPRC6A (although the species tested is not always stated) (Pi et al., 2011, 2012; Pi and Quarles, 2012; Oury et al., 2013), suggesting that the signaling of the receptor may not be limited to $\mathrm{G} \alpha_{\mathrm{q}}$-coupled pathways originally reported for L-amino acids. Furthermore, recent reports have used computational approaches to predict the binding locus for OCN on GPRC6A 
(Pi et al., 2016) and suggested that OCN shares its binding site with testosterone (De Toni et al., 2016). However, two further laboratories have evaluated the pharmacology of mouse GPRC6A and failed to replicate either the agonist activity of OCN or GPRC6Amediated cAMP signaling (Jacobsen et al., 2013; Rueda et al., 2016), leading both groups to conclude that the receptor is primarily a $\mathrm{G} \alpha_{\mathrm{q}}$-coupled, basic L-amino acid receptor.

Given the complexities of the pharmacology of GPRC6A, it is unclear whether targeting the receptor therapeutically could replicate the effects of OCN; small-molecule chemistry targeting the receptor has been restricted to a limited number of low-potency negative allosteric modulators, which target the transmembrane domain of GPRC6A (Gloriam et al., 2011; Johansson et al., 2015). A further challenge is the potential differences between orthologs of the receptor; a recent study explained the challenges of expressing and interrogating the pharmacology of the human receptor by virtue of an insertion/deletion variation in the third intracellular loop that leads to intracellular retention (Jørgensen et al., 2017). It remains unclear whether the pharmacology of the human receptor differs markedly from its murine ortholog_or indeed, what role the human receptor might have in vivo if not expressed at the cell surface.

\section{Hydroxycarboxylic Acid Receptor 2 (GPR109A)}

The receptor for nicotinic acid, or niacin, was identified in 2003 and subsequently shown to be highly expressed in adipocytes and immune cells (Wanders and Judd, 2011). Activation of hydroxycarboxylic acid receptor $2\left(\mathrm{HCA}_{2}\right)$ by niacin in adipocytes causes inhibition of lipolysis, but also via the epidermal Langerhans cells the harmless, yet unwanted side effect of flushing (Wanders and Judd, 2011). In addition to binding niacin, the receptor also binds the SCFA butyrate, suggesting that $\mathrm{HCA}_{2}$ is involved in gut homeostasis, similar to the FFARs described above. KO mouse studies revealed a marked increase in adiponectin concentrations (Plaisance et al., 2009). Interestingly, niacin activation of $\mathrm{HCA}_{2}$ stimulates sodium-glucose cotransporter 1 and GLUT2 jejunal glucose uptake, indicating potential additional benefits that would improve glycemic control (Wong et al., 2015).

The pursuit of $\mathrm{HCA}_{2}$ agonists for the treatment of T2DM has recently increased, with a focus on identifying compounds without the flushing side effect. GSK256073, in a trial of 39 diabetic patients, caused a significant decrease in serum nonesterified fatty acids and glucose concentrations when dosed three times over 2 days (Dobbins et al., 2013). These improvements in glucose tolerance were attributed to an increase in insulin sensitivity with an associated decrease in insulin concentrations. Encouragingly, no flushing or adverse effects on the gastrointestinal tract were observed (Sprecher et al., 2015). However, recent data from a randomized 12-week trial revealed that GSK256073 did not meet its primary end point in reducing $\mathrm{HbA1c}$ compared with placebo (Dobbins et al., 2015). Lack of efficacy could be due to an inability of the compound to produce sustained suppression of plasma nonesterified fatty acid concentrations, thought to be required for the effects on insulin sensitivity.

However, a recent publication has questioned the validity of targeting $\mathrm{HCA}_{2}$ (Fraterrigo et al., 2012). Niaspan, an extended release form of niacin, produced insulin resistance in skeletal muscle, most probably due to increased levels of adiponectin. These opposing effects suggest that further investigation of $\mathrm{HCA}_{2}$ as a target is required. Its close homolog, $\mathrm{HCA}_{3}$ (GPR109B), differs by only 15 amino acids and results from a gene duplication only present in humans (Ahmed et al., 2009). This receptor does not bind niacin with high affinity, but, like $\mathrm{HCA}_{2}$, couples to $\mathrm{G} \alpha_{\mathrm{i}}$. 3-OH-octanoic acid is an endogenous ligand for $\mathrm{HCA}_{3}$ (Ahmed et al., 2009), and activation of the receptor by this ligand controls adipocyte lipolysis by a negative feedback loop involving counteraction of prolipolytic stimuli in situations of increased fatty acid oxidation. Targeting $\mathrm{HCA}_{3}$ may therefore be an alternative approach to $\mathrm{HCA}_{2}$, especially if the $\mathrm{HCA}_{2}$-mediated side effects can be avoided.

\section{N. Melatonin Receptors $\left(M T_{1} R\right.$ and $\left.M T_{2} R\right)$}

Melatonin (MT) is primarily secreted by the pineal gland during the dark phase, but can also be secreted to a lesser extent from the innate immune system, the gastrointestinal tract, and the retina. The effects of MT are mediated by two homologous but distinct GPCRs, namely $\mathrm{MT}_{1} \mathrm{R}$ and $\mathrm{MT}_{2} \mathrm{R}$, encoded by two distinct genes, MTNR1A and MTNR1B, respectively. MTs are $\mathrm{G} \alpha_{\mathrm{i}^{-}}$ coupled and expressed in a cell-specific fashion in mice and in humans (see Jockers et al., 2016 for recent review). MTs are involved in numerous physiologic and neuroendocrine functions. Interest in MT in the pathogenesis of T2DM derived initially from three independent genome-wide association studies that led to the identification of several frequent polymorphisms located near the MTNR1B gene that were associated with increased fasting plasma glucose, a reduction of early insulin response to glucose, and ultimately an increased risk of developing T2DM (Bouatia-Naji et al., 2009; Lyssenko et al., 2009). This genetic association is very robust and was subsequently replicated by several groups in other populations (Ronn et al., 2009; Renström et al., 2015). Surprisingly, the influence of MT on insulin secretion is still debated, with conflicting results generated in vitro using rodent and human islets (Lyssenko et al., 2009; Costes et al., 2015). Furthermore, MT receptors are expressed at low levels in both $\alpha$ - and $\beta$-cells. In a recent study, Tuomi et al. (2016) demonstrated elegantly that the common rs10830963 variant located in the MTNR1B intron is an expression quantitative trait locus conferring 
increased expression (two- to fourfold) of the receptor in islets, as measured by RNA Seq in 204 Scandinavian donors, whereas MTNR1A expression is not altered by either genotypes (GG versus CC).

MT inhibits glucose-stimulated insulin secretion in INS-1 cells overexpressing $M T N R 1 B / \mathrm{MT}_{2} \mathrm{R}$ by, at least in part, reducing glucose-stimulated cAMP production. Pertussis toxin treatment completely abolished this effect (Tuomi et al., 2016). The authors also characterized in depth the phenotype of $M t 2^{-1-} \mathrm{KO}$ mice. These mice display increased insulin release in response to an intravenous glucose tolerance test and impaired hepatic insulin sensitivity, as determined by hyperinsulinemic-euglycemic clamp. This exacerbated insulin response was documented both ex vivo and in vivo. Increased $\beta$-cell mass and increased cAMP levels in response to glucose stimulation are the main reasons for this altered insulin response. Tuomi et al. (2016) showed that MT treatment at bedtime for 3 months in nondiabetic individuals resulted in a significant reduction in insulin secretion in GG allele carriers (Tuomi et al., 2016). It is noteworthy that sleep duration and quality were similar in both groups in response to MT treatment. Another group reported a negative effect of acute MT treatment on glucose clearance during a 2-hour oral glucose tolerance test in a genotype-specific fashion in healthy young female athletes (Garaulet et al., 2015). Taken together, these studies suggest that increased MT signaling is a risk factor for T2DM. However, analysis of rare loss-of-function MTNR1B variants suggested that reduced MT signaling increases T2DM risk (Prokopenko et al., 2009; Bonnefond et al., 2012). Furthermore, reduced MT secretion is associated with an increased risk for diabetes in the general population (McMullan et al., 2013). Although it appears difficult to assign a definitive role of MT on insulin secretion from all these human and mouse genetic studies, the role of MT and its receptors in the CNS on energy and glucose homeostasis should be further investigated because sleep restriction and circadian misalignment are recognized as major risk factors for the development of cardio-metabolic diseases (Scheer et al., 2009). Indeed, Lane et al. (2016) recently reported that the $M T N R 1 B$ risk allele influences dynamics of MT secretion with consequences on the sleep/wake cycle. Nevertheless, the species-specific receptor distribution and downstream biology complicate translation of the preclinical pharmacology into the clinical space for cardio-metabolic diseases.

\section{G Protein-Coupled Receptors and Obesity- Induced Type 2 Diabetes Mellitus}

\section{A. C-C Motif Chemokine Receptor 2}

CCR2 belongs to the $\mathrm{C}-\mathrm{C}$ motif chemokine receptor (CCR) and C-X-C motif chemokine receptor superfamily.
These receptors are involved in many inflammatory responses and are expressed on multiple inflammatory cell types, including monocytes, macrophages, T-cells, and B-cells. However, these receptors are also widely expressed in the periphery, with some expression also located in the CNS. Like many chemokine receptors, CCR2 is activated by multiple agonists, including CCL7 (MCP-3), CCL8 (MCP-2), CCL11 (eotoxin), and CCL13 (MCP-4), which all bind with similar low nanomolar affinities. However, the principal agonist for CCR2 is CCL2 (MCP-1), which binds with sub-nM affinity. Many of these agonists also bind to multiple receptors, for example, CCL2 binds with low affinity ( $>1000$-fold compared with CCR2) to CCR4. This multireceptor, multiligand behavior suggests that a large degree of redundancy must occur across the biologic functions (Boring et al., 1997). It has been shown that the different endogenous ligands for CCR2 are able to bind and stabilize different confirmations of the receptor, enabling the activation of both $\mathrm{G}$ protein-dependent and independent pathways (Berchiche et al., 2011). In addition, multiple binding sites have been identified using radiolabeled antagonists (Zweemer et al., 2013). Recently, the crystal structure of inactive CCR2 was solved using a T4L fusion construct (Zheng et al., 2016) in a ternary complex with both an orthosteric (BMS-681) and an allosteric [CCR2-RA-(R)] antagonist, indicating that the receptor is able to accommodate multiple ligands at any one time. The next challenge is to identify whether the receptor could accommodate multiple endogenous agonists simultaneously, thus giving an insight into redundancy among chemokine receptors/ligands. However, this may prove too challenging, as to date over $90 \%$ of all GPCR structures have been solved in the inactive confirmation, with either an antagonist and/or an allosteric modulator bound. Of note, the double-antagonist CCR2 crystal structure is the most inactive, therefore most stable, structure solved (Zheng et al., 2016). Therefore, a double-agonist bound structure may yet be outside the current technical capabilities.

During infection, activation of the innate immune response occurs, and binding of CCL2 to CCR2 causes recruitment of Ly6C ${ }^{\text {hi }}$ monocytes. The levels of expression of CCL2 rapidly increase within inflamed tissues, and its release is further stimulated by the release of proinflammatory mediators (Shi and Pamer, 2011), although the mechanism involved is largely unknown. It has been suggested that CCL2 produces a chemokine gradient toward the site of inflammation, enabling the recruitment of circulating monocytes (Shi and Pamer, 2011). In addition, the levels of CCR2 expression are also modulated during tissue inflammation, by granulocytemacrophage colony-stimulating factor (Croxford et al., 2015). Therefore, the increased levels of both receptor and ligand help resolve the site of infection.

It is unsurprising, based on the expression profile of CCR2, that this receptor has been implicated in the 
pathophysiology of T2DM. In $C c r 2^{-/-}$mice fed a highfat diet, a reduction in food intake, macrophage recruitment, inflammatory markers in adipose tissue, and an improvement in glucose homeostasis and insulin sensitivity have been reported (Weisberg et al., 2006). A similar phenotype has also been described with siRNA knockdown of CCR2 (Kim et al., 2016). In global Ccr2 $2^{-/-}$ and hematopoietic (bone marrow) $\mathrm{Ccr}^{-{ }^{--}}$mice fed a high-fat diet for 12 weeks, flow cytometry revealed differences in the $\mathrm{F} 4 / 80^{+}$myeloid cell population compared with their wild-type counterparts. In the adipose tissue from all cohorts, CD $11 b^{\text {hi }} \mathrm{F} 4 / 80^{+}$cells were detected; however, in both $\mathrm{KOs}$, a population of $\mathrm{CD} 11 \mathrm{~b}^{\mathrm{lo}} \mathrm{F} 4 / 80^{\mathrm{lo}}$ was seen. It was only when this population of cells was absent from adipose tissue, following 20 weeks of the high-fat diet, that improvements in adipose tissue inflammation were detected (Gutierrez et al., 2011). Loss of CCR2 resulted in the accumulation of $\mathrm{CD} 11 \mathrm{~b}^{\mathrm{lo}} \mathrm{F} 4 / 80^{\mathrm{lo}}$ cells in adipose tissue, whereas in wild-type mice transient expression of these cells was identified. No explanation was given as to why these cells disappeared with increased feeding. Further data reveal that migration of monocytes from bone marrow is dependent on both CCR2 and CCL2, whereas migration of monocytes from the circulation into inflamed tissues appears to be dependent on CCR2, CCL2, and CCL7 (Tsou et al., 2007). To further explore monocyte migration, Kawano et al. (2016) generated colonic macrophage-specific $C \mathrm{cr} 2^{-/-}(M-C c r 2 K O)$ and intestinal epithelial cell-specific tamoxifen-inducible $C c l 2^{-/-}$ (Vil-Ccl2KO) mice. Although both strains gained significant body weight when fed a high-fat diet, only the $C \mathrm{cr} 2^{-/-}$displayed improved glucose tolerance and insulin sensitivity. Interestingly, in a whole-body $\mathrm{Ccl}^{-/-}$, when fed a similar diet, an increase in adiposity and metabolic dysfunction was observed, suggesting that global CCL2 is required for the protection of sensitive metabolic tissues (Cranford et al., 2016).

As there is clear redundancy in the immune system and receptor/ligand polygamy, targeting chemokine receptors therapeutically, especially with small molecules, may appear extremely challenging. However, recent data have shown some promise with CCR2 antagonists for the treatment of T2DM and its associated complications, nonalcoholic fatty liver disease/ NASH. In mice fed a high-fat diet, and in $d b / d b$ mice, CCX140-B (ChemoCentryx) fully blocked the recruitment of inflammatory macrophages into adipose tissue, resulting in an improvement in glucose homeostasis, insulin sensitivity, hepatic glycogen, and triglyceride content (Sullivan et al., 2013a). Similar effects were observed in human CCR2 knock-in mice, with no increase in circulating CCL2 levels in plasma, or increased blood monocyte numbers (Sullivan et al., 2013b). Encouragingly, treatment of 110 patients with T2DM and nephropathy in a phase II trial with CCX140-B resulted in renoprotection and improved glucose handling, although there was no overall improvement in insulin resistance (de Zeeuw et al., 2015). As no improvement in insulin resistance was seen, the compound is now being further investigated in models of chronic kidney disease. Similarly, use of the Spiegelmer, NOX-E36 (Noxxon; emapticap pegol), which neutralizes CCL2, has shown promise in a phase IIa exploratory study in patients with T2DM and albuminuria (Menne et al., 2017) and in mouse models of NASH and chronic hepatic injury (Baeck et al., 2012). Finally, use of a dual CCR2/CCR5 antagonist Cenicriviroc (Allergan) has shown potent anti-inflammatory and antifibrotic effects in animal models of NASH and fibrosis (Lefebvre et al., 2016). A phase IIb combination study with the farnesoid $\mathrm{X}$ receptor agonist LJN 452 (Novartis) is planned to assess safety, efficacy, and tolerability. Results of these studies may further enforce the rationale for targeting CCR2 for the treatment of T2DM and chronic liver diseases.

\section{B. FFAR4 (GPR120)}

FFAR4 is a metabolite-sensing FFA GPCR activated by unsaturated long-chain FFAs (Hirasawa et al., 2005), leading to the release of GLP-1 and an increase in circulating insulin. Omega-3 polyunsaturated fatty acids display the highest potency for FFAR4 in vitro (Im, 2016), but other endogenous ligands also activate FFAR4, including docosahexaenoic acid and eicosapentaenoic acid (Oh et al., 2010; Kim et al., 2015). FFAR4 exerts its biologic effects by both $\mathrm{G}$ protein-dependent and independent pathways. Coupling to $\mathrm{G} \alpha_{\mathrm{q}}$ causes release of intracellular $\mathrm{Ca}^{2}$ to promote the release of cholecystokinin and GLP-1. In addition, activation of extracellular signal-regulated kinase phosphorylation and phosphoinositide 3-kinase leads to AKT phosphorylation and GLUT4 translocation, leading to the regulation of adipogenesis and adipogenic differentiation $(\mathrm{Li}$ et al., 2015a). Moreover, FFAR4 is expressed specifically on mouse pancreatic $\delta$-islet cells, but not on $\beta$-islet cells, and activation of FFAR4 in these cells regulates the secretion of somatostatin (Stone et al., 2014).

FFAR4 may also inhibit inflammation promoted by other mechanisms. For example, activation of Tolllike receptor 4 and TNF receptor by lipopolysaccharide (LPS) and TNF- $\alpha$, respectively, causes TGF- $\beta-$ activated kinase 1 binding protein and TGF- $\beta$-activated kinase 1 to colocalize and activate the IKK, JNK, and NF- $\kappa \mathrm{B}$ pathways, leading to inflammation $(\mathrm{Oh}$ et al., 2010; Talukdar et al., 2011; Li et al., 2015a; Liu et al., 2015b; Ulven and Christiansen, 2015). However, agonist activation of FFAR4 causes recruitment of $\beta$-arrestin 2 , leading to the sequestration of TGF- $\beta-$ activated kinase 1 binding protein away from TGF- $\beta$ activated kinase 1 and an anti-inflammatory effect (Oh et al., 2010), suggesting that signaling bias may exist for this receptor, and this may provide a means of inhibiting inflammation. 
FFAR4 is highly expressed in adipose tissue, proinflammatory macrophages, and eosinophils (Konno et al., 2015), suggesting that it may provide a link between metabolic diseases and inflammation (Oh et al., 2010). In the monocyte RAW 264.7 cell line and mouse intraperitoneal macrophages, FFAR4-mediated anti-inflammatory effects, including reduction of proinflammatory M1, increased anti-inflammatory M2 macrophage levels and reduced cytokine levels that were abrogated when FFAR4 was knocked down using siRNA. Similar effects were observed in $\mathrm{Ffar}^{-/-}$mice on a high-fat diet with or without omega-3 polyunsaturated fatty acid supplementation. The KO phenotype indicated that a FFAR4 agonist may alleviate insulin resistance. GW9508, which has FFAR1 and FFAR4 agonist activity (Briscoe et al., 2006), inhibited LPS-induced phosphorylation of JNK, IKK $\beta, \mathrm{I} \kappa \beta$ degradation, cytokine secretion, and inflammatory gene expression in RAW 264.7 cells. A FFAR4-selective agonist Cpd A (Oh et al., 2014) reduced chronic inflammation in obese mice, but also improved insulin sensitivity, glucose tolerance, and decreased hyperinsulinemia. Other FFAR4 agonists have since been developed and display similar attributes ( $\mathrm{Li}$ et al., 2015a; Liu et al., 2015b; Ulven and Christiansen, 2015). However, FFAR4 desensitizes rapidly upon chronic activation, which has hampered the progression of FFAR4 agonists in the clinic (Alvarez-Curto et al., 2016). Furthermore, increased FFAR4 expression and signaling both in vitro and in vivo are associated with an increase in colorectal carcinoma tumor growth, promotion of angiogenesis, increased motility, and induced epithelial-mesenchymal transition of human colorectal carcinoma cells (Wu et al., 2013). Further studies are therefore required to delineate the effects of FFAR4 agonist activity on tumor progression before committing to human studies.

\section{GPR21}

GPR21 is an orphan receptor that couples to $\mathrm{G} \alpha_{\mathrm{q}}$ (Bresnick et al., 2003), but as no ligand, synthetic or endogenous, has yet been identified, further conclusions about signaling are difficult to make. It has been suggested that the endogenous ligand is a FFA (Kakarala and Jamil, 2014), and/or could be found within serum as serum-starved GPR21-expressing cells display reduced AKT phosphorylation (Leonard et al., 2016). However, no strong experimental evidence has emerged to confirm these findings.

Two independent studies using Gpr $21^{-1-}$ mice indicate that GPR21 may be involved in obesity-induced insulin resistance (Gardner et al., 2012; Osborn et al., 2012). In the first study, Gpr $21^{-/-}$mice showed a robust improvement in glucose tolerance and systemic insulin sensitivity after a high-fat diet, culminating in a modest lean phenotype that was suggested to be due to a reduction in tissue inflammation caused by a decrease in the migratory ability of macrophages into adipose tissue (Osborn et al., 2012). To examine these effects in a human model, lentiviral short hairpin RNA knockdown of GPR21 in a human monocyte-like cell line (U-937) was performed and showed similar inhibition of migration. In the second study, there was a clear reduction in proinflammatory mediators in Gpr $21^{-/-}$mice, along with an improvement in glucose tolerance and systemic insulin sensitivity after a high-fat diet (Gardner et al., 2012). However, subsequently, the same group generated an alternative $\mathrm{KO}$ mouse model using transcription activator-like effector nucleases (TALENS) technology (Wang et al., 2016b). This was necessary because the Gpr21 gene resides within the intron of the RAB GTPase-activating protein 1 (Rabgap1) gene, and the authors showed that this gene was disrupted in the original Gpr $21^{-1-}$ mice. Although there was no effect on the expression of Rabgap1 in the TALENS Gpr21 $1^{-1-} \mathrm{KO}$, no improvement in glycemic control was reported. Why no beneficial phenotype was observed is unclear, and no head-tohead comparison between the two KO strains was made, nor was a high-fat diet regimen tested in the TALENS KO, making interpretation of these observations challenging. However, although GPR21 appears to be a promising target, the orphan status, and the lack of any suitable tool molecule, inhibits further investigation.

\section{GPR35}

GPR35 is an orphan GPCR that is highly expressed in the pancreas, immune cells, and to a lesser extent adipose tissue, liver, and skeletal muscle (MacKenzie et al., 2011). Recently, it has been reported that GPR35 can be activated by the chemokine CXCL17 (MaravillasMontero et al., 2015). Based on this finding, it was proposed that the receptor be renamed C-X-C motif chemokine receptor 8 (Maravillas-Montero et al., 2015). Multiple other endogenous ligands have been associated with GPR35, including kynurenic acid and 2-oleoyl lysophosphatidic acid (Shore and Reggio, 2015). In addition, a vast array of synthetic agonists and antagonists has been developed for this receptor (for a summary, please see MacKenzie et al., 2011). To further add complexities to the pharmacology of GPR35, the concept of ortholog selectivity and ligand bias has been demonstrated for this receptor (Milligan, 2011). Although the expression profile of GPR35 would support its potential as a suitable target for obesity-induced T2DM, little experimental data exist to support this theory. It has been shown that CXCL17 causes the migration of macrophages from the lungs of wild-type mice, but not from $\mathrm{Cxcl17^{-/- }}$ mice, indicating a role in inflammation (Maravillas-Montero et al., 2015). However, no further investigation into the potential metabolic effect of GPR35 was performed. Further studies are required to elucidate the potential of GPR35, 
such as a high-fat diet study in $G p r 35^{-/-}$animals. Unfortunately, due to the complex pharmacology and multiple endogenous ligands known, interest in this receptor is perhaps limited.

\section{E. GPR84}

Medium-chain fatty acids (MCFAs), including capric, undecanoic, and lauric acid, bind and activate GPR84, resulting in $\mathrm{Ca}^{2+}$ mobilization and inhibition of cAMP (Wang et al., 2006). These responses are pertussis toxin sensitive, indicating that GPR84 couples to $\mathrm{G} \alpha_{\mathrm{i} / \mathrm{o}}$. GPR84 is predominantly present on immune cells and more particularly in monocytes, macrophages, and neutrophils (Wang et al., 2006). In the periphery, GPR84 is mainly expressed in bone marrow, spleen, lung, and peripheral blood leukocytes. In the CNS, GPR84 expression is restricted to microglia (Bouchard et al., 2007). Interestingly, MCFAs caused significant upregulation of the LPS-induced proinflammatory cytokine IL-12 p40 (IL12B), which has a pivotal role in promoting cell-mediated immunity by inducing and maintaining Th1 cell responses and inhibiting Th2 response. In agreement with these results, Gpr84 $4^{-1-}$ mice had increased levels of Th2 cytokines (Wang et al., 2006). Furthermore, under proinflammatory conditions, Gpr84 expression in macrophages is increased (Talukdar et al., 2011) and regulates TNF- $\alpha$ secretion from LPS-stimulated macrophages (Müller et al., 2017). Moreover, Nagasaki et al. (2012) demonstrated, using a 3T3-L1 (adipocyte) and RAW264.7 (macrophage) coculture, a clear upregulation in Gpr84 expression in the presence of TNF- $\alpha$, with a concomitant downregulation of adiponectin, and concluded that the release of TNF- $\alpha$ from infiltrating macrophages caused the increase in Gpr84 expression.

To add further weight to this hypothesis, Suzuki et al. (2013) demonstrated, using MCFAs and a surrogate agonist, 6- $n$-octylaminouracil, that GPR84 agonists caused chemotaxis of human leukocytes and macrophages. Likewise, LPS stimulation increased the release of proinflammatory cytokines, IL- 8 and TNF- $\alpha$, in these human leukocytes and macrophages, respectively. Finally, Gpr84 was shown to be upregulated under inflammatory conditions in both the microglia and astrocytes (Madeddu et al., 2015). In line with these observations, Gpr84 gene deficiency significantly reduces microgliosis (Audoy-Remus et al., 2015). Because several groups have established a role for glia in energy balance regulation and obesity pathogenesis (see Douglass et al., 2017 for review), it is tempting to speculate that GPR84 may have a metabolic role under inflammatory conditions. Although all these studies suggest a link between GPR84 and chronic low-grade inflammation, its role in energy and glucose homeostasis remains unclear. Surprisingly, recent studies performed by Du Toit et al. (2017) indicate that Gpr84 gene deficiency does not significantly affect glucose or energy homeostasis in response to a low-chain fatty acid (LCFA)- or MCFA-enriched diet. Interestingly, the authors found that $G p r 84^{-1-} \mathrm{KO}$ mice displayed significantly increased liver triglyceride levels in response to the low-chain fatty acid diet, although infiltration of immune cells in the liver as well as expression markers of inflammation under these conditions was unfortunately not documented. Whether the exacerbated steatosis observed in Gpr $84^{-1-} \mathrm{KO}$ animals is due to cross-talk between hepatocytes and immune cells remains to be established. Further studies using KO mice and bone marrow transplantations are required to determine whether there is a major role for GPR84 in metabolic disease.

\section{F. Leukotriene $B L T_{1}$ Receptor}

Leukotriene $\mathrm{B}_{4}\left(\mathrm{LTB}_{4}\right)$ is a proinflammatory cytokine produced from arachidonic acid (Tager and Luster, 2003) that binds with high and low affinity to the leukotriene $\mathrm{B} 4 \mathrm{R} 1\left(\mathrm{BLT}_{1}\right)$ and $\mathrm{B} 4 \mathrm{R} 2\left(\mathrm{BLT}_{2}\right)$ receptors, respectively. In addition, other lipoxygenase and thromboxane synthase products, including 12-hydroxyeicosatetraenoic acid and 12-hydroxyheptadecatrienoic acid, bind and activate the $\mathrm{BLT}_{2}$ receptor. In a recent study, $B l t_{1}^{-1-}$ mice placed on a high-fat diet had reduced levels of $\mathrm{CD}_{11} \mathrm{~b}^{+}$monocytes in adipose tissue compared with the wild-type controls, a clear reduction in M1 proinflammatory adipose tissue macrophages, and a reduction in the expression of proinflammatory chemokine genes, including IL 6 and Ccl2 (Spite et al., 2011). Deletion of the $\mathrm{BLT}_{1}$ receptor reduced inflammation in adipose tissue and liver, resulting in protection from hepatic steatosis and insulin resistance. This suggested a novel role for the $\mathrm{BLT}_{1}$ receptor in monocyte chemotaxis, culminating in high levels of chronic inflammation and obesity.

It has also been shown that $\mathrm{LTB}_{4}$ causes insulin resistance in obese mice associated with enhanced macrophage chemotaxis, stimulation of proinflammatory pathways, reduced insulin-stimulated glucose uptake into myocytes, and impaired insulin-mediated suppression of hepatic glucose secretion in mouse hepatocytes ( $\mathrm{Li}$ et al., 2015b). All of these effects were reversed or severely blunted in the $B l t_{1}^{-1-}$ mouse. These studies suggest that $\mathrm{BLT}_{1}$ receptor inhibition may be a useful way of preventing obesity-induced T2DM. However, to date, all studies have been performed using only $B l t_{1}^{-l-}$ mice. As $\mathrm{LTB}_{4}$ also binds and activates the $\mathrm{BLT}_{2}$ receptor, further studies are required to understand whether a compensatory mechanism is present, using the $B l t_{2}^{-1-}$, or a double $B l t_{1}^{-1-} / B l t_{2}^{-1-} \mathrm{KO}$. Finally, whereas the $\mathrm{BLT}_{1}$ receptor appears to couple exclusively to $\mathrm{G} \alpha_{\mathrm{i}}$ proteins, the $\mathrm{BLT}_{2}$ receptor couples to both $\mathrm{G} \alpha_{\mathrm{i}}$ and $\mathrm{G} \alpha_{\mathrm{q}}$ proteins (Yokomizo et al., 2001). Therefore, perhaps specifically inhibiting the activation of the $\mathrm{G} \alpha_{\mathrm{i}}$ pathway via the $\mathrm{BLT}_{1}$ receptor may be sufficient to obtain the desired anti-inflammatory phenotype. 


\section{G. SUCNR1 (GPR91)}

SUCNR1 is expressed on immature dendritic cells and macrophages. The receptor is activated by succinate, which is generated from citrate via the tricarboxylic acid cycle. Citrate is involved in the production of prostaglandin and fatty acid synthesis. Under homeostasis, M2 macrophages break down succinate by succinate dehydrogenase (SDH). However, under levels of high inflammation, SDH is inhibited by itaconate, an antimicrobial metabolite (Nemeth et al., 2016), and inhibition of SDH causes accumulation of succinate within the macrophage. This accumulation adds to the inflammatory phenotype by increasing LPS-induced hypoxia-inducible factor $1 \alpha$ equilibrium, resulting in an increase in IL-1 $\beta$ expression (Van den Bossche et al., 2017). Activation of SUCNR1 causes maturation and migration of these immune cells into metabolic tissues, further increasing the production of IL- $1 \beta$ (Rubic et al., 2008). Moreover, activation of SUCNR1 by succinate causes a SUCNR1-dependent recycling of the agonist fueling the inflammation in a paracrine mechanism, a concept termed immunometabolism (Littlewood-Evans et al., 2016). In differentiated bone marrow macrophages obtained from wild-type and Sucnr $1^{-/-}$mice, macrophage migration and IL-1 $\beta$ production were abrogated in the KO animals (Littlewood-Evans et al., 2016). However, Sucnr1 ${ }^{-/-}$mice fed a high-fat diet for 16 weeks exhibited improved insulin resistance (Carmone et al., 2015; van Diepen et al., 2017), whereas a similar study only showed an initial improvement, with the animals becoming progressively hyperglycemic (McCreath et al., 2015). Finally, in another study, Sucnr1 $1^{-1-}$ mice developed dry age-related macular degeneration (Favret et al., 2013). Due to these conflicting data sets, interest in targeting SUCNR1 for metabolic disorders may be limited.

\section{Conclusions and Perspectives}

The worldwide prevalence of type 2 diabetes mellitus is increasing rapidly, culminating in a significant financial and resource burden on the various health care systems and health professionals. Although in recent years there has been a moderate increase in the number of available treatments, including the newly approved sodium-glucose cotransporter-2 inhibitors (Chao, 2014), there is a clear unmet medical need. The roles of $\beta$-cell dysfunction and insulin resistance were

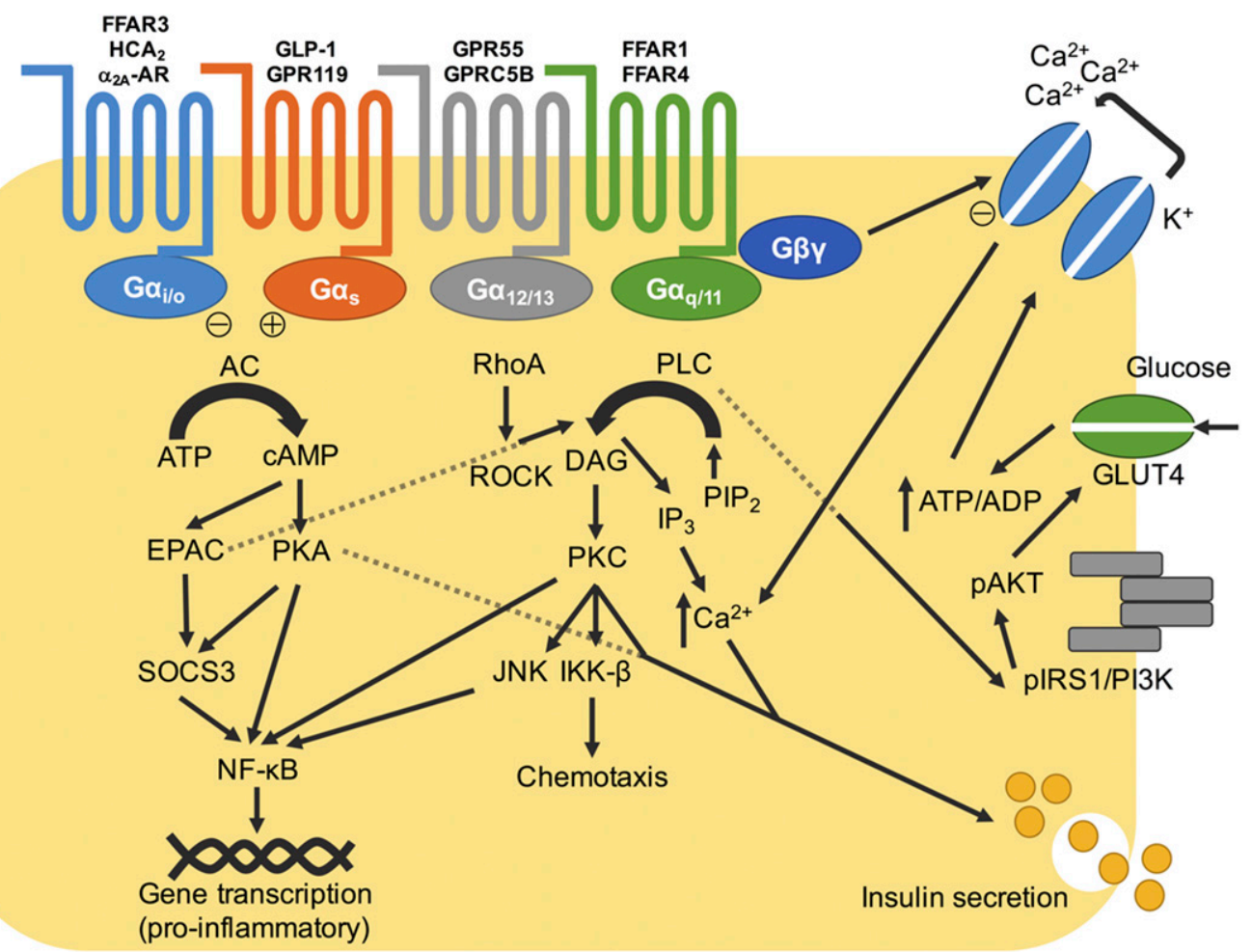

Fig. 4. Schematic diagram of a pancreatic $\beta$-cell illustrating GPCR-involved $\beta$-cell dysfunction, insulin resistance, and obesity-induced T2DM and the signaling pathways of downstream $\mathrm{G}$ protein activation. Typically, insulin secretion occurs when glucose is taken up into the cell, which increases the ATP/ADP ratio. This change causes a reduction in the ATP-regulated $\mathrm{K}^{+}$channel activity. The increased levels of $\mathrm{K}^{+}$within the cell cause depolarization of the cellular membrane, which in turn causes opening of voltage-dependent $\mathrm{Ca}^{2+}$ channels. This influx of $\mathrm{Ca}^{2+}$ causes the exocytosis of insulin from insulin-storing secretory granules. Phosphorylation of the insulin receptor by phospholipase $\mathrm{C}$ and activation of the serine/threonine kinase pathway enhance glucose uptake into the relevant tissues. The involvement of GPCRs causes an increase in the level of insulin exocytosis either via the stimulation of the $\mathrm{G} \alpha_{\mathrm{s}}$ signaling pathway, which causes an increase in protein kinase $\mathrm{A}$, or via the $\mathrm{G} \alpha_{\mathrm{q}}$ signaling pathway, which causes an increase in both PKC and intracellular $\mathrm{Ca}^{2+}$ concentrations. The levels of insulin secretion can be inhibited by the G $\beta \gamma$ subunit complex, inhibiting the voltage-dependent $\mathrm{Ca}^{2+}$ channel activity. GPCRs can also cause an increase in the gene transcription of multiple proinflammatory genes and increased chemotaxis via activation of IKK- $\beta$, JNK, and NF- $\kappa$ B signaling pathways. 
first described by Yalow and Berson (1960) when they developed an immunoassay to measure endogenous plasma insulin levels in humans and observed clear differences in nondiabetic and early diabetic subjects following an oral glucose tolerance test. As such, the main focus for developing new therapeutics over the past 50 years has been to improve $\beta$-cell function and insulin sensitivity. However, more recently, the effect of low-grade tissue inflammation has emerged as a mechanism to target therapeutically (Donath, 2014). Nonetheless, there is some debate within the diabetes field as to whether inflammation is a driver of insulin resistance and T2DM or just an additional symptom of the disease. To definitively answer this question, an increase in clinical trials using anti-inflammatory compounds is required. In addition, whether targeting GPCRs for this indication will prove successful is still yet unknown, but combinational therapies including anti-IL- $1 \beta$ and antiTNF with small molecular weight agonists or antagonists may prove beneficial, complementing effects on the different pathways involved in inflammation.

The number of GPCRs potentially involved in the development and progression of T2DM has dramatically increased since the beginning of the millennium, likely due to greater access to transgenic animal models and an increased understanding of GPCR pharmacology. With over $40 \%$ of all marketed drugs activating or inhibiting GPCRs (Wise et al., 2002), targeting these proteins is likely to be both tractable and beneficial. However, many challenges in targeting these receptors still persist, particularly as many are orphans or, like FFA and chemokine receptors, have a large number of endogenous ligands that make tractability more challenging. Changes in the expression and/or function of the receptors highlighted in this review can influence the development and progression of T2DM. In some cases, the downstream signaling pathways involved are known, at least for $\beta$-cells (Fig. 4), but more studies are required within other relevant metabolic tissues, including skeletal muscle, liver, and brain to dissect the interplay of downstream events. Interestingly, no clear relationship between specific $\mathrm{G}$ proteins and the disease exists (Fig. 4; Table 1).

A lack of understanding of basic receptor pharmacology makes development of therapeutic compounds immensely difficult. Even with KO animal data supporting many of these GPCRs, as promising targets, progressing these into candidates for drug development remains challenging. In many cases, limited or conflicting data have hindered the translation of many of these $\mathrm{KO}$ studies into humans and indicate that more rigorous early-stage target validation is required. Nonetheless, with the constant advances of technological platforms, including improved compound screening techniques, deorphanization strategies, novel targeting mechanisms, including signaling bias and allostery, and the explosion in GPCR structural biology, the possibility of successfully targeting these proteins is ever increasing. Further research into these highly desirable targets is warranted, but may require novel approaches ultimately led by an increased understanding of the pathophysiology of T2DM.

\section{Authorship Contributions}

Wrote or contributed to the writing of the manuscript: Riddy, Delerive, Summers, Sexton, Langmead.

\section{References}

Abbracchio MP, Boeynaems J-M, Barnard EA, Boyer JL, Kennedy C, Miras-Portugal MT, King BF, Gachet C, Jacobson KA, Weisman GA, et al. (2003) Characterization of the UDP-glucose receptor (re-named here the P2Y14 receptor) adds diversity to the P2Y receptor family. Trends Pharmacol Sci 24:52-55.

Abdel-Magid AF (2015) Prostaglandin EP3 receptor antagonists may provide novel treatment for diabetes. ACS Med Chem Lett 6:626-627.

Ahmed K, Tunaru S, Langhans C-D, Hanson J, Michalski CW, Kölker S, Jones PM, Okun JG, and Offermanns S (2009) Deorphanization of GPR109B as a receptor for the $\beta$-oxidation intermediate 3-OH-octanoic acid and its role in the regulation of lipolysis. J Biol Chem 284:21928-21933.

Ahrén B (2009) Islet G protein-coupled receptors as potential targets for treatment of type 2 diabetes. Nat Rev Drug Discov 8:369-385.

Ahrén B, Holst JJ, and Efendic S (2000) Antidiabetogenic action of cholecystokinin-8 in type 2 diabetes. J Clin Endocrinol Metab 85:1043-1048.

Al-Barazanji K, McNulty J, Binz J, Generaux C, Benson W, Young A, and Chen L (2015) Synergistic effects of a GPR119 agonist with metformin on weight loss in diet-induced obese mice. J Pharmacol Exp Ther 353:496-504.

Alexander SPH, Kelly E, Marrion N, Peters JA, Benson HE, Faccenda E, Pawson AJ, Sharman JL, Southan C, Buneman OP, et al.; CGTP Collaborators (2015) The concise guide to pharmacology 2015/16: overview. Br J Pharmacol 172:5729-5743.

Alvarez-Curto $\mathrm{E}$, Inoue $\mathrm{A}$, Jenkins $\mathrm{L}$, Raihan $\mathrm{SZ}$, Prihandoko $\mathrm{R}$, Tobin $\mathrm{AB}$ and Milligan G (2016) Targeted elimination of $G$ proteins and arrestins defines their specific contributions to both intensity and duration of $\mathrm{G}$ protein-coupled receptor signaling. J Biol Chem 291:27147-27159.

Alvarez-Curto E and Milligan G (2016) Metabolism meets immunity: the role of free fatty acid receptors in the immune system. Biochem Pharmacol 114:3-13.

Arch JR (2002) beta(3)-Adrenoceptor agonists: potential, pitfalls and progress. Eur $J$ Pharmacol 440:99-107.

Arch JR (2008) The discovery of drugs for obesity, the metabolic effects of leptin and variable receptor pharmacology: perspectives from beta3-adrenoceptor agonists. Naunyn Schmiedebergs Arch Pharmacol 378:225-240.

Arch JR, Ainsworth AT, Cawthorne MA, Piercy V, Sennitt MV, Thody VE, Wilson C, and Wilson S (1984) Atypical beta-adrenoceptor on brown adipocytes as target for anti-obesity drugs. Nature 309:163-165.

Audoy-Rémus J, Bozoyan L, Dumas A, Filali M, Lecours C, Lacroix S, Rivest S, Tremblay ME, and Vallières L (2015) GPR84 deficiency reduces microgliosis, but accelerates dendritic degeneration and cognitive decline in a mouse model of Alzheimer's disease. Brain Behav Immun 46:112-120.

Baeck C, Wehr A, Karlmark KR, Heymann F, Vucur M, Gassler N, Huss S, Klussmann S, Eulberg D, Luedde T, et al. (2012) Pharmacological inhibition of the chemokine CCL2 (MCP-1) diminishes liver macrophage infiltration and steatohepatitis in chronic hepatic injury. Gut 61:416-426.

Baggio LL and Drucker DJ (2014) Glucagon-like peptide-1 receptors in the brain controlling food intake and body weight. J Clin Invest 124:4223-4226.

Balhuizen A, Kumar R, Amisten S, Lundquist I, and Salehi A (2010) Activation of $\mathrm{G}$ protein-coupled receptor 30 modulates hormone secretion and counteracts cytokine-induced apoptosis in pancreatic islets of female mice. Mol Cell Endocrinol 320:16-24.

Beak J, Huang W, Parker JS, Hicks ST, Patterson C, Simpson PC, Ma A, Jin J, and Jensen BC (2017) An oral selective alpha-1A adrenergic receptor agonist prevents doxorubicin cardiotoxicity. JACC Basic Transl Sci 2:39-53.

Berchiche YA, Gravel S, Pelletier M-E, St-Onge G, and Heveker N (2011) Different effects of the different natural $\mathrm{CC}$ chemokine receptor $2 \mathrm{~b}$ ligands on beta-arrestin recruitment, Goi signaling, and receptor internalization. Mol Pharmacol 79: 488-498.

Bindels LB, Dewulf EM, and Delzenne NM (2013) GPR43/FFA2: physiopathological relevance and therapeutic prospects. Trends Pharmacol Sci 34:226-232.

Bjursell M, Admyre T, Göransson M, Marley AE, Smith DM, Oscarsson J, and Bohlooly-Y M (2011) Improved glucose control and reduced body fat mass in free fatty acid receptor 2-deficient mice fed a high-fat diet. Am J Physiol Endocrinol Metab 300:E211-E220.

Blad CC, Tang C, and Offermanns S (2012) G protein-coupled receptors for energy metabolites as new therapeutic targets. Nat Rev Drug Discov 11:603-619.

Blodgett DM, Nowosielska A, Afik S, Pechhold S, Cura AJ, Kennedy NJ, Kim S, Kucukural A, Davis RJ, Kent SC, et al. (2015) Novel observations from nextgeneration RNA sequencing of highly purified human adult and fetal islet cell subsets. Diabetes 64:3172-3181.

Blundell J, Finlayson G, Axelsen M, Flint A, Gibbons C, Kvist T, and Hjerpsted JB (2017) Effects of once-weekly semaglutide on appetite, energy intake, control of eating, food preference and body weight in subjects with obesity. Diabetes Obes Metab 19:1242-1251.

Bologa CG, Revankar CM, Young SM, Edwards BS, Arterburn JB, Kiselyov AS, Parker MA, Tkachenko SE, Savchuck NP, Sklar LA, et al. (2006) Virtual and 
biomolecular screening converge on a selective agonist for GPR30. Nat Chem Biol 2:207-212.

Bolognini D, Moss CE, Nilsson K, Petersson AU, Donnelly I, Sergeev E, König GM, Kostenis E, Kurowska-Stolarska M, Miller A, et al. (2016) A novel allosteric activator of free fatty acid 2 receptor displays unique gi-functional bias. J Biol Chem 291:18915-18931.

Bonnefond A, Clément N, Fawcett K, Yengo L, Vaillant E, Guillaume J-L, Dechaume A, Payne F, Roussel R, Czernichow S, et al.; Meta-Analysis of Glucose and InsulinRelated Traits Consortium (MAGIC) (2012) Rare MTNR1B variants impairing melatonin receptor $1 \mathrm{~B}$ function contribute to type 2 diabetes. Nat Genet $\mathbf{4 4}$ 297-301.

Boring L, Gosling J, Chensue SW, Kunkel SL, Farese RV Jr, Broxmeyer HE, and Charo IF (1997) Impaired monocyte migration and reduced type 1 (Th1) cytokine responses in $\mathrm{C}-\mathrm{C}$ chemokine receptor 2 knockout mice. $J$ Clin Invest 100 $2552-2561$.

Boschmann M, Krupp G, Luft FC, Klaus S, and Jordan J (2002) In vivo response to alpha(1)-adrenoreceptor stimulation in human white adipose tissue. Obes Res 10: $555-558$

Bouatia-Naji N, Bonnefond A, Cavalcanti-Proença C, Sparsø T, Holmkvist J Marchand M, Delplanque J, Lobbens S, Rocheleau G, Durand E, et al. (2009) A variant near MTNR1B is associated with increased fasting plasma glucose levels and type 2 diabetes risk. Nat Genet 41:89-94.

Bouchard C, Pagé J, Bédard A, Tremblay P, and Vallières L (2007) G protein-coupled receptor 84, a microglia-associated protein expressed in neuroinflammatory conditions. Glia 55:790-800.

Bresnick JN, Skynner HA, Chapman KL, Jack AD, Zamiara E, Negulescu P, Beaumont K, Patel S, and McAllister G (2003) Identification of signal transduction pathways used by orphan g protein-coupled receptors. Assay Drug Dev Technol 1:239-249.

Briscoe CP, Peat AJ, McKeown SC, Corbett DF, Goetz AS, Littleton TR, McCoy DC, Kenakin TP, Andrews JL, Ammala C, et al. (2006) Pharmacological regulation of insulin secretion in MIN6 cells through the fatty acid receptor GPR40: identification of agonist and antagonist small molecules. Br J Pharmacol 148:619-628.

Brothers SP and Wahlestedt C (2010) Therapeutic potential of neuropeptide Y (NPY) receptor ligands. EMBO Mol Med 2:429-439.

Brown AJ, Goldsworthy SM, Barnes AA, Eilert MM, Tcheang L, Daniels D, Muir AI, Wigglesworth MJ, Kinghorn I, Fraser NJ, et al. (2003) The orphan G proteincoupled receptors GPR41 and GPR43 are activated by propionate and other short chain carboxylic acids. $J$ Biol Chem 278:11312-11319.

Burant CF (2013) Activation of GPR40 as a therapeutic target for the treatment of type 2 diabetes. Diabetes Care 36 (Suppl 2):S175-S179.

Buse JB, Rosenstock J, Sesti G, Schmidt WE, Montanya E, Brett JH, Zychma M, and Blonde L; LEAD-6 Study Group (2009) Liraglutide once a day versus exenatide twice a day for type 2 diabetes: a 26 -week randomised, parallel-group, multinational, open-label trial (LEAD-6). Lancet 374:39-47.

Camell CD, Nguyen KY, Jurczak MJ, Christian BE, Shulman GI, Shadel GS, and Dixit VD (2015) Macrophage-specific de novo synthesis of ceramide is dispensable for inflammasome-driven inflammation and insulin resistance in obesity. $J$ Biol Chem 290:29402-29413.

Cantini G, Mannucci E, and Luconi M (2016) Perspectives in GLP-1 research: new targets, new receptors. Trends Endocrinol Metab 27:427-438.

Carmone C, Robben J, Ariza A, Bekkenkamp M, Kurstjens S, Devuyst O, and Deen P (2015) The succinate receptor 1 is a physiological regulator of the reninangiontensin aldosterone system. FASEB $J \mathbf{2 9}$.

Carter RL, Fricks IP, Barrett MO, Burianek LE, Zhou Y, Ko H, Das A, Jacobson KA Lazarowski ER, and Harden TK (2009) Quantification of gi-mediated inhibition of adenylyl cyclase activity reveals that UDP is a potent agonist of the human P2Y14 receptor. Mol Pharmacol 76:1341-1348.

Cattaneo M (2015) P2Y12 receptors: structure and function. J Thromb Haemost 13 (Suppl 1):S10-S16.

Cawthorne MA, Carroll MJ, Levy AL, Lister CA, Sennitt MV, Smith SA, and Young P (1984) Effects of novel beta-adrenoceptor agonists on carbohydrate metabolism: relevance for the treatment of non-insulin-dependent diabetes. Int J Obes 8 (Suppl 1):93-102.

Ceddia RP, Lee D, Maulis MF, Carboneau BA, Threadgill DW, Poffenberger G, Milne G, Boyd KL, Powers AC, McGuinness OP, et al. (2016) The PGE2 EP3 receptor regulates diet-induced adiposity in male mice. Endocrinology 157:220-232.

Cerf ME (2013) Beta cell dysfunction and insulin resistance. Front Endocrinol (Lausanne) 4:37.

Chandra V, Karamitri A, Richards P, Cormier F, Ramond C, Jockers R, Armanet M, Albagli-Curiel O, and Scharfmann R (2016) Extracellular acidification stimulates GPR68 mediated IL-8 production in human pancreatic $\beta$ cells. Sci Rep 6:25765.

Chao EC (2014) SGLT-2 inhibitors: a new mechanism for glycemic control. Clin Diabetes 32:4-11.

Chawla A, Nguyen KD, and Goh YPS (2011) Macrophage-mediated inflammation in metabolic disease. Nat Rev Immunol 11:738-749.

Chen T, Zheng X, Ma X, Bao Y, Ni Y, Hu C, Rajani C, Huang F, Zhao A, Jia W, et al. (2016) Tryptophan predicts the risk for future type 2 diabetes. PLoS One 11: e0162192.

Cheng C, Chiu HJ, Loh el-W, Chan CH, Hwu TM, Liu YR, and Lan TH (2012) Association of the ADRA1A gene and the severity of metabolic abnormalities in patients with schizophrenia. Prog Neuropsychopharmacol Biol Psychiatry 36:205-210.

Cheng JT, Liu IM, Yen ST, and Chen PC (2000) Role of alpha1A-adrenoceptor in the regulation of glucose uptake into white adipocyte of rats in vitro. Auton Neurosci 84:140-146.

Cheng S-B, Graeber CT, Quinn JA, and Filardo EJ (2011) Retrograde transport of the transmembrane estrogen receptor, G-protein-coupled-receptor-30 (GPR30/GPER) from the plasma membrane towards the nucleus. Steroids 76:892-896.

Chorvat RJ (2013) Peripherally restricted CB1 receptor blockers. Bioorg Med Chem Lett 23:4751-4760.
Chu CA, Sindelar DK, Igawa K, Sherck S, Neal DW, Emshwiller M, and Cherrington $\mathrm{AD}(2000)$ The direct effects of catecholamines on hepatic glucose production occur via alpha(1)- and beta(2)-receptors in the dog. Am J Physiol Endocrinol Metab 279: E463-E473.

Chu Z-L, Carroll C, Alfonso J, Gutierrez V, He H, Lucman A, Pedraza M, Mondala H, Gao H, Bagnol D, et al. (2008) A role for intestinal endocrine cell-expressed G protein-coupled receptor 119 in glycemic control by enhancing glucagon-like peptide-1 and glucose-dependent insulinotropic peptide release. Endocrinology 149:2038-2047.

Clemmensen C, Pehmøller C, Klein AB, Ratner C, Wojtaszewski JF, and BräunerOsborne H (2013a) Enhanced voluntary wheel running in GPRC6A receptor knockout mice. Physiol Behav 118:144-151.

Clemmensen C, Smajilovic S, Madsen AN, Klein AB, Holst B, and Bräuner-Osborne $\mathrm{H}$ (2013b) Increased susceptibility to diet-induced obesity in GPRC6A receptor knockout mice. J Endocrinol 217:151-160.

Cohen LJ, Kang H-S, Chu J, Huang Y-H, Gordon EA, Reddy BVB, Ternei MA, Craig JW, and Brady SF (2015) Functional metagenomic discovery of bacterial effectors in the human microbiome and isolation of commendamide, a GPCR G2A/132 agonist. Proc Natl Acad Sci USA 112:E4825-E4834.

Cooper ME (2012) Diabetes: treating diabetic nephropathy: still an unresolved issue. Nat Rev Endocrinol 8:515-516.

Corrêa-Oliveira R, Fachi JL, Vieira A, Sato FT, and Vinolo MAR (2016) Regulation of immune cell function by short-chain fatty acids. Clin Transl Immunology 5:e73.

Costes S, Boss M, Thomas AP, and Matveyenko AV (2015) Activation of melatonin signaling promotes $\beta$-cell survival and function. Mol Endocrinol 29:682-692.

Cranford TL, Enos RT, Velázquez KT, McClellan JL, Davis JM, Singh UP, Nagarkatti M, Nagarkatti PS, Robinson CM, and Murphy EA (2016) Role of MCP-1 on inflammatory processes and metabolic dysfunction following high-fat feedings in the FVB/N strain. Int $J$ Obes 40:844-851.

Croxford AL, Lanzinger M, Hartmann FJ, Schreiner B, Mair F, Pelczar P, Clausen BE, Jung S, Greter M, and Becher B (2015) The cytokine GM-CSF drives the inflammatory signature of CCR2+ monocytes and licenses autoimmunity. Immunity 43: 502-514.

Davis KE, Carstens EJ, Irani BG, Gent LM, Hahner LM, and Clegg DJ (2014) Sexually dimorphic role of $\mathrm{G}$ protein-coupled estrogen receptor (GPER) in modulating energy homeostasis. Horm Behav 66:196-207.

Day JW, Ottaway N, Patterson JT, Gelfanov V, Smiley D, Gidda J, Findeisen H, Bruemmer D, Drucker DJ, Chaudhary N, et al. (2009) A new glucagon and GLP-1 co-agonist eliminates obesity in rodents. Nat Chem Biol 5:749-757.

De A and DiMarchi RD (2010) Synthesis and characterization of ester-based prodrugs of glucagon-like peptide 1. Biopolymers 94:448-456.

Defossa E and Wagner M (2014) Recent developments in the discovery of FFA1 receptor agonists as novel oral treatment for type 2 diabetes mellitus. Bioorg Med Chem Lett 24:2991-3000.

Defronzo RA (2009) Banting lecture: from the triumvirate to the ominous octet: a new paradigm for the treatment of type 2 diabetes mellitus. Diabetes 58:773-795.

Dehvari N, Hutchinson DS, Nevzorova J, Dallner OS, Sato M, Kocan M, Merlin J, Evans BA, Summers RJ, and Bengtsson T (2012) $\beta$ (2)-Adrenoceptors increase translocation of GLUT4 via GPCR kinase sites in the receptor C-terminal tail. $\mathrm{Br} J$ Pharmacol 165:1442-1456.

Dennis MK, Burai R, Ramesh C, Petrie WK, Alcon SN, Nayak TK, Bologa CG, Leitao A, Brailoiu E, Deliu E, et al. (2009) In vivo effects of a GPR30 antagonist. Nat Chem Biol 5:421-427.

Dennis MK, Field AS, Burai R, Ramesh C, Petrie WK, Bologa CG, Oprea TI, Yamaguchi Y, Hayashi S, Sklar LA, et al. (2011) Identification of a GPER/GPR30 antagonist with improved estrogen receptor counterselectivity. J Steroid Biochem Mol Biol 127:358-366.

De Toni L, Guidolin D, De Filippis V, Tescari S, Strapazzon G, Santa Rocca M, Ferlin A, Plebani M, and Foresta C (2016) Osteocalcin and sex hormone binding globulin compete on a specific binding site of GPRC6A. Endocrinology 157:4473-4486.

Dezaki K, Sone H, and Yada T (2008) Ghrelin is a physiological regulator of insulin release in pancreatic islets and glucose homeostasis. Pharmacol Ther 118:239-249.

de Zeeuw D, Bekker P, Henkel E, Hasslacher C, Gouni-Berthold I, Mehling H, Potarca A, Tesar V, Heerspink HJ, and Schall TJ; CCX140-B Diabetic Nephropathy Study Group (2015) The effect of CCR2 inhibitor CCX140-B on residual albuminuria in patients with type 2 diabetes and nephropathy: a randomised trial. Lancet Diabetes Endocrinol 3:687-696.

Di Nisio A, Rocca MS, Fadini GP, De Toni L, Marcuzzo G, Marescotti MC, Sanna M, Plebani M, Vettor R, Avogaro A, et al. (2017) The rs2274911 polymorphism in GPRC6A gene is associated with insulin resistance in normal weight and obese subjects. Clin Endocrinol (Oxf) 86:185-191.

Dobbins R, Byerly R, Gaddy R, Gao F, Mahar K, Napolitano A, Ambery P, and Le Monnier de Gouville AC (2015) GSK256073 acutely regulates NEFA levels via HCA2 agonism but does not achieve durable glycaemic control in type 2 diabetes: a randomised trial. Eur $J$ Pharmacol 755:95-101.

Dobbins RL, Shearn SP, Byerly RL, Gao FF, Mahar KM, Napolitano A, Nachbaur GJ, and Le Monnier de Gouville AC (2013) GSK256073, a selective agonist of G-protein coupled receptor 109A (GPR109A) reduces serum glucose in subjects with type 2 diabetes mellitus. Diabetes Obes Metab 15:1013-1021.

Donath MY (2014) Targeting inflammation in the treatment of type 2 diabetes: time to start. Nat Rev Drug Discov 13:465-476.

Donath MY and Shoelson SE (2011) Type 2 diabetes as an inflammatory disease. Nat Rev Immunol 11:98-107.

Donnelly D (2012) The structure and function of the glucagon-like peptide-1 receptor and its ligands. $B r J$ Pharmacol 166:27-41.

Douglass JD, Dorfman MD, and Thaler JP (2017) Glia: silent partners in energy homeostasis and obesity pathogenesis. Diabetologia 60:226-236.

Du Toit E, Browne L, Irving-Rodgers H, Massa HM, Fozzard N, Jennings MP, and Peak IR (2017) Effect of GPR84 deletion on obesity and diabetes developmen in mice fed long chain or medium chain fatty acid rich diets. Eur J Nutr 36:485. 
Du X, Kim Y-J, Lai S, Chen X, Lizarzaburu M, Turcotte S, Fu Z, Liu Q, Zhang Y, Motani A, et al. (2012) Phenylalanine derivatives as GPR142 agonists for the treatment of type II diabetes. Bioorg Med Chem Lett 22:6218-6223.

Dungan KM, Povedano ST, Forst T, González JGG, Atisso C, Sealls W, and Fahrbach JL (2014) Once-weekly dulaglutide versus once-daily liraglutide in metformin-treated patients with type 2 diabetes (AWARD-6): a randomised, open-label, phase 3, non-inferiority trial. Lancet 384:1349-1357.

Emilsson V, Summers RJ, Hamilton S, Liu YL, and Cawthorne MA (1998) The effects of the beta3-adrenoceptor agonist BRL 35135 on UCP isoform mRNA expression. Biochem Biophys Res Commun 252:450-454.

Emorine LJ, Marullo S, Briend-Sutren MM, Patey G, Tate K, Delavier-Klutchko C, and Strosberg $\mathrm{AD}$ (1989) Molecular characterization of the human beta 3-adrenergic receptor. Science 245:1118-1121.

Engel KMY, Schröck K, Teupser D, Holdt LM, Tönjes A, Kern M, Dietrich K, Kovacs P, Krügel U, Scheidt HA, et al. (2011) Reduced food intake and body weight in mice deficient for the G protein-coupled receptor GPR82. PLoS One 6:e29400.

Eriksson P, Dahlman I, Rydén M, Hoffstedt J, and Arner P (2004) Relationship between beta-2 adrenoceptor gene haplotypes and adipocyte lipolysis in women. Int $J$ Obes Relat Metab Disord 28:185-190.

Esser N, Legrand-Poels S, Piette J, Scheen AJ, and Paquot N (2014) Inflammation as a link between obesity, metabolic syndrome and type 2 diabetes. Diabetes Res Clin Pract 105:141-150.

Esser N, Paquot N, and Scheen AJ (2015) Anti-inflammatory agents to treat or prevent type 2 diabetes, metabolic syndrome and cardiovascular disease. Expert Opin Investig Drugs 24:283-307.

Evans BA, Broxton N, Merlin J, Sato M, Hutchinson DS, Christopoulos A, and Summers RJ (2011) Quantification of functional selectivity at the human $\alpha(1 \mathrm{~A})$-adrenoceptor. Mol Pharmacol 79:298-307.

Evans BA, Papaioannou M, Bonazzi VR, and Summers RJ (1996) Expression of beta 3-adrenoceptor mRNA in rat tissues. Br J Pharmacol 117:210-216.

Evans BA, Papaioannou M, Hamilton S, and Summers RJ (1999) Alternative splicing generates two isoforms of the beta3-adrenoceptor which are differentially expressed in mouse tissues. Br J Pharmacol 127:1525-1531.

Evans BA, Sato M, Sarwar M, Hutchinson DS, and Summers RJ (2010) Liganddirected signalling at beta-adrenoceptors. Br J Pharmacol 159:1022-1038.

Færch K, Johansen NB, Witte DR, Lauritzen T, Jørgensen ME, and Vistisen D (2015) Relationship between insulin resistance and $\beta$-cell dysfunction in subphenotypes of prediabetes and type 2 diabetes. J Clin Endocrinol Metab 100:707-716.

Færch K, Witte DR, Tabák AG, Perreault L, Herder C, Brunner EJ, Kivimäki M, and Vistisen D (2013) Trajectories of cardiometabolic risk factors before diagnosis of three subtypes of type 2 diabetes: a post-hoc analysis of the longitudinal Whitehall II cohort study. Lancet Diabetes Endocrinol 1:43-51.

Favret S, Binet F, Lapalme E, Leboeuf D, Carbadillo J, Rubic T, Picard E, Mawambo G, Tetreault N, Joyal JS, et al. (2013) Deficiency in the metabolite receptor SUCNR1 (GPR91) leads to outer retinal lesions. Aging (Albany NY) 5:427-444

Flatt PR (2008) Dorothy Hodgkin lecture 2008: gastric inhibitory polypeptide (GIP) revisited: a new therapeutic target for obesity-diabetes? Diabet Med 25:759-764.

Flechtner-Mors M, Jenkinson CP, Alt A, Biesalski HK, Adler G, and Ditschuneit HH (2004) Sympathetic regulation of glucose uptake by the alpha1-adrenoceptor in human obesity. Obes Res 12:612-620.

Flock G, Holland D, Seino Y, and Drucker DJ (2011) GPR119 regulates murine glucose homeostasis through incretin receptor-dependent and independent mechanisms. Endocrinology 152:374-383.

Fowler MJ (2008) Microvascular and macrovascular complications of diabetes. Clin Diabetes 26:77-82.

Fraterrigo G, Fabbrini E, Mittendorfer B, O'Rahilly S, Scherer PE, Patterson BW, and Klein S (2012) Relationship between changes in plasma adiponectin concentration and insulin sensitivity after niacin therapy. Cardiorenal Med 2:211-217.

Fricks IP, Maddileti S, Carter RL, Lazarowski ER, Nicholas RA, Jacobson KA, and Harden TK (2008) UDP is a competitive antagonist at the human P2Y14 receptor. J Pharmacol Exp Ther 325:588-594

Galbo T, Perry RJ, Jurczak MJ, Camporez J-PG, Alves TC, Kahn M, Guigni BA, Serr J, Zhang D, Bhanot S, et al. (2013) Saturated and unsaturated fat induce hepatic insulin resistance independently of TLR-4 signaling and ceramide synthesis in vivo. Proc Natl Acad Sci USA 110:12780-12785.

Garaulet M, Gómez-Abellán P, Rubio-Sastre P, Madrid JA, Saxena R, and Scheer FAJL (2015) Common type 2 diabetes risk variant in MTNR1B worsens the deleterious effect of melatonin on glucose tolerance in humans. Metabolism 64 1650-1657.

García-Pérez L-E, Álvarez M, Dilla T, Gil-Guillén V, and Orozco-Beltrán D (2013) Adherence to therapies in patients with type 2 diabetes. Diabetes Ther 4:175-194.

Gardner J, Wu S, Ling L, Danao J, Li Y, Yeh W-C, Tian H, and Baribault H (2012) Gprotein-coupled receptor GPR21 knockout mice display improved glucose tolerance and increased insulin response. Biochem Biophys Res Commun 418:1-5.

Gautam D, Jeon J, Li JH, Han S-J, Hamdan FF, Cui Y, Lu H, Deng C, Gavrilova O, and Wess J (2008) Metabolic roles of the M3 muscarinic acetylcholine receptor studied with M3 receptor mutant mice: a review. J Recept Signal Transduct Res 28:93-108.

Ghorbani M, Shafiee Ardestani M, Gigloo SH, Cohan RA, Inanlou DN, and Ghorbani $P$ (2012) Anti diabetic effect of CL 316,243 (a ß3-adrenergic agonist) by down regulation of tumour necrosis factor (TNF- $\alpha$ ) expression. PLoS One 7:e45874.

Gloriam DE, Wellendorph P, Johansen LD, Thomsen AR, Phonekeo K, Pedersen DS, and Bräuner-Osborne $\mathrm{H}$ (2011) Chemogenomic discovery of allosteric antagonists at the GPRC6A receptor. Chem Biol 18:1489-1498.

Goldfine AB, Buck JS, Desouza C, Fonseca V, Chen Y-DI, Shoelson SE, Jablonski KA, and Creager MA; TINSAL-FMD (Targeting Inflammation Using Salsalate in Type 2 Diabetes-Flow-Mediated Dilation) Ancillary Study Team (2013) Targeting in flammation using salsalate in patients with type 2 diabetes: effects on flowmediated dilation (TINSAL-FMD). Diabetes Care 36:4132-4139.

Goldfine AB, Fonseca V, and Shoelson SE (2011) Therapeutic approaches to target inflammation in type 2 diabetes. Clin Chem 57:162-167.
González-Manchón C, Ayuso MS, and Parrilla R (1989) Control of hepatic gluconeogenesis: role of fatty acid oxidation. Arch Biochem Biophys 271:1-9.

Graaf Cd, Donnelly D, Wootten D, Lau J, Sexton PM, Miller LJ, Ahn JM, Liao J, Fletcher MM, Yang D, et al. (2016) Glucagon-like peptide-1 and its class B G protein-coupled receptors: a long march to therapeutic successes. Pharmacol Rev 68:954-1013.

Gruden G, Barutta F, Kunos G, and Pacher P (2016) Role of the endocannabinoid system in diabetes and diabetic complications. Br J Pharmacol 173:1116-1127.

Guo L, Parker DL, Zang Y, Sweis RF, Liu W, Sherer EC, Buist N, Terebetski J, Kelly T, Bugianesi R, et al. (2016) Discovery and optimization of a novel triazole series of GPR142 agonists for the treatment of type 2 diabetes. ACS Med Chem Lett 7: 1107-1111.

Gutierrez DA, Kennedy A, Orr JS, Anderson EK, Webb CD, Gerrald WK, and Hasty $\mathrm{AH}$ (2011) Aberrant accumulation of undifferentiated myeloid cells in the adipose tissue of CCR2-deficient mice delays improvements in insulin sensitivity. Diabetes 60:2820-2829.

Gylfe E and Gilon P (2014) Glucose regulation of glucagon secretion. Diabetes Res Clin Pract 103:1-10.

Hamdouchi C, Kahl SD, Patel Lewis A, Cardona GR, Zink RW, Chen K, Eessalu TE, Ficorilli JV, Marcelo MC, Otto KA, et al. (2016) The discovery, preclinical, and early clinical development of potent and selective GPR40 agonists for the treatment of type 2 diabetes mellitus (LY2881835, LY2922083, and LY2922470). J Med Chem 59:10891-10916

Hansen HS, Rosenkilde MM, Holst JJ, and Schwartz TW (2012) GPR119 as a fat sensor. Trends Pharmacol Sci 33:374-381.

Hansotia T, Maida A, Flock G, Yamada Y, Tsukiyama K, Seino Y, and Drucker DJ (2007) Extrapancreatic incretin receptors modulate glucose homeostasis, body weight, and energy expenditure. J Clin Invest 117:143-152.

Harmar AJ, Fahrenkrug J, Gozes I, Laburthe M, May V, Pisegna JR, Vaudry D, Vaudry H, Waschek JA, and Said SI (2012) Pharmacology and functions of receptors for vasoactive intestinal peptide and pituitary adenylate cyclase-activating polypeptide: IUPHAR review 1. Br J Pharmacol 166:4-17.

Heit JJ, Karnik SK, and Kim SK (2006) Intrinsic regulators of pancreatic beta-cell proliferation. Annu Rev Cell Dev Biol 22:311-338.

Henstridge CM, Balenga NA, Schröder R, Kargl JK, Platzer W, Martini L, Arthur S, Penman J, Whistler JL, Kostenis E, et al. (2010) GPR55 ligands promote receptor coupling to multiple signalling pathways. Br J Pharmacol 160:604-614.

Hirasawa A, Tsumaya K, Awaji T, Katsuma S, Adachi T, Yamada M, Sugimoto Y, Miyazaki S, and Tsujimoto G (2005) Free fatty acids regulate gut incretin glucagon-like peptide-1 secretion through GPR120. Nat Med 11:90-94

Hohenhaus DM, Schaale K, Le Cao KA, Seow V, Iyer A, Fairlie DP, and Sweet MJ (2013) An mRNA atlas of G protein-coupled receptor expression during primary human monocyte/macrophage differentiation and lipopolysaccharide-mediated activation identifies targetable candidate regulators of inflammation. Immunobiology 218:1345-1353.

Hotamisligil GS (2010) Endoplasmic reticulum stress and the inflammatory basis of metabolic disease. Cell 140:900-917.

Hotamisligil GS, Arner P, Caro JF, Atkinson RL, and Spiegelman BM (1995) Increased adipose tissue expression of tumor necrosis factor-alpha in human obesity and insulin resistance. $J$ Clin Invest 95:2409-2415.

Hotamisligil GS, Shargill NS, and Spiegelman BM (1993) Adipose expression of tumor necrosis factor-alpha: direct role in obesity-linked insulin resistance. Science 259:87-91.

Houthuijzen JM (2016) For better or worse: FFAR1 and FFAR4 signaling in cancer and diabetes. Mol Pharmacol 90:738-743.

Huang C, Yuan L, and Cao S (2015a) Endogenous GLP-1 as a key self-defense molecule against lipotoxicity in pancreatic islets. Int $J$ Mol Med 36:173-185.

Huang X-P, Karpiak J, Kroeze WK, Zhu H, Chen X, Moy SS, Saddoris KA, Nikolova VD, Farrell MS, Wang S, et al. (2015b) Allosteric ligands for the pharmacologically dark receptors GPR68 and GPR65. Nature 527:477-483.

Hui H, Farilla L, Merkel P, and Perfetti R (2002) The short half-life of glucagon-like peptide-1 in plasma does not reflect its long-lasting beneficial effects. Eur $J$ Endocrinol 146:863-869.

Hunt DG, Ding Z, and Ivy JL (2002) Clenbuterol prevents epinephrine from antagonizing insulin-stimulated muscle glucose uptake. J Appl Physiol (1985) 92: $1285-1292$

Husted AS, Trauelsen M, Rudenko O, Hjorth SA, and Schwartz TW (2017) GPCRmediated signaling of metabolites. Cell Metab 25:777-796.

Hutchinson DS and Bengtsson T (2006) AMP-activated protein kinase activation by adrenoceptors in L6 skeletal muscle cells: mediation by alpha1-adrenoceptors causing glucose uptake. Diabetes 55:682-690.

Iepsen EW, Torekov SS, and Holst JJ (2015) Liraglutide for type 2 diabetes and obesity: a 2015 update. Expert Rev Cardiovasc Ther 13:753-767.

Ikeda M, Tsuji H, Nakamura S, Ichiyama A, Nishizuka Y, and Hayaishi O (1965) Studies on the biosynthesis of nicotinamide adenine dinucleotide. II. A role of picolinic carboxylase in the biosynthese of nicotinamide adenine dinucelotide from tryptophan in mammals. J Biol Chem 240:1395-1401.

Im D-S (2016) Functions of omega-3 fatty acids and FFA4 (GPR120) in macrophages. Eur J Pharmacol 785:36-43.

Inoue D, Tsujimoto G, and Kimura I (2014) Regulation of energy homeostasis by GPR41. Front Endocrinol (Lausanne) 5:81.

Iqbal J, Walsh MT, Hammad SM, and Hussain MM (2017) Sphingolipids and lipoproteins in health and metabolic disorders. Trends Endocrinol Metab 28:506-518 .

Jacobsen SE, Nørskov-Lauritsen L, Thomsen AR, Smajilovic S, Wellendorph P, Larsson NH, Lehmann A, Bhatia VK, and Bräuner-Osborne H (2013) Delineation of the GPRC6A receptor signaling pathways using a mammalian cell line stably expressing the receptor. J Pharmacol Exp Ther 347:298-309.

Jaswal JS, Keung W, Wang W, Ussher JR, and Lopaschuk GD (2011) Targeting fatty acid and carbohydrate oxidation-a novel therapeutic intervention in the ischemic and failing heart. Biochim Biophys Acta 1813:1333-1350. 
Jazayeri A, Rappas M, Brown AJH, Kean J, Errey JC, Robertson NJ, Fiez-Vandal C, Andrews SP, Congreve M, Bortolato A, et al. (2017) Crystal structure of the GLP-1 receptor bound to a peptide agonist. Nature 546:254-258.

Jensen BC, O'Connell TD, and Simpson PC (2011) Alpha-1-adrenergic receptors: targets for agonist drugs to treat heart failure. J Mol Cell Cardiol 51:518-528.

Jensen L, Helleberg H, Roffel A, van Lier JJ, Bjørnsdottir I, Pedersen PJ, Rowe E, Derving Karsbøl J, and Pedersen ML (2017) Absorption, metabolism and excretion of the GLP-1 analogue semaglutide in humans and nonclinical species. Eur $J$ Pharm Sci 104:31-41.

Jockers R, Delagrange P, Dubocovich ML, Markus RP, Renault N, Tosini G, Cecon E, and Zlotos DP (2016) Update on melatonin receptors: IUPHAR Review 20. Br Pharmacol 173:2702-2725.

Johansson H, Boesgaard MW, Nørskov-Lauritsen L, Larsen I, Kuhne S, Gloriam DE, Bräuner-Osborne H, and Sejer Pedersen D (2015) Selective allosteric antagonists for the G protein-coupled receptor GPRC6A based on the 2-phenylindole privileged structure scaffold. $J$ Med Chem 58:8938-8951.

Jørgensen S, Have CT, Underwood CR, Johansen LD, Wellendorph P, Gjesing AP, Jørgensen CV, Quan S, Rui G, Inoue A, et al. (2017) Genetic variations in the human G protein-coupled receptor class C, group 6, member A (GPRC6A) control cell surface expression and function. $J$ Biol Chem 292:1524-1534.

Jourdan T, Szanda G, Rosenberg AZ, Tam J, Earley BJ, Godlewski G, Cinar R, Liu Z, Liu J, Ju C, et al. (2014) Overactive cannabinoid 1 receptor in podocytes drives type 2 diabetic nephropathy. Proc Natl Acad Sci USA 111:E5420-E5428.

Kakarala KK and Jamil K (2014) Sequence-structure based phylogeny of GPCR class A rhodopsin receptors. Mol Phylogenet Evol 74:66-96.

Kalupahana NS, Moustaid-Moussa N, and Claycombe KJ (2012) Immunity as a link between obesity and insulin resistance. Mol Aspects Med 33:26-34.

Kang S-U (2013) GPR119 agonists: a promising approach for T2DM treatment? A SWOT analysis of GPR119. Drug Discov Today 18:1309-1315.

Kawano Y, Nakae J, Watanabe N, Kikuchi T, Tateya S, Tamori Y, Kaneko M, Abe T Onodera M, and Itoh H (2016) Colonic pro-inflammatory macrophages cause insulin resistance in an intestinal Ccl2/Ccr2-dependent manner. Cell Metab 24 295-310.

Kieffer TJ, Heller RS, Unson CG, Weir GC, and Habener JF (1996) Distribution of glucagon receptors on hormone-specific endocrine cells of rat pancreatic islets. Endocrinology 137:5119-5125.

Kim J, Chung K, Choi C, Beloor J, Ullah I, Kim N, Lee KY, Lee SK, and Kumar P (2016) Silencing CCR2 in macrophages alleviates adipose tissue inflammation and the associated metabolic syndrome in dietary obese mice. Mol Ther Nucleic Acids 5:e280.

Kim N, Lee JO, Lee HJ, Kim HI, Kim JK, Lee YW, Lee SK, Kim SJ, Park SH, and Kim HS (2015) Endogenous ligand for GPR120, docosahexaenoic acid, exerts benign metabolic effects on the skeletal muscles via AMP-activated protein kinase pathway. J Biol Chem 290:20438-20447.

Kim YJ, Sano T, Nabetani T, Asano Y, and Hirabayashi Y (2012) GPRC5B activates obesity-associated inflammatory signaling in adipocytes. Sci Signal 5(251):ra85.

Kimple ME, Keller MP, Rabaglia MR, Pasker RL, Neuman JC, Truchan NA, Bra HK, and Attie AD (2013) Prostaglandin E2 receptor, EP3, is induced in diabetic islets and negatively regulates glucose- and hormone-stimulated insulin secretion. Diabetes 62:1904-1912.

Kimura I, Ozawa K, Inoue D, Imamura T, Kimura K, Maeda T, Terasawa K, Kashihara D, Hirano K, Tani T, et al. (2013) The gut microbiota suppresses insulin-mediated fat accumulation via the short-chain fatty acid receptor GPR43. Nat Commun 4:1829.

Konno Y, Ueki S, Takeda M, Kobayashi Y, Tamaki M, Moritoki Y, Oyamada H, Itoga M, Kayaba H, Omokawa A, et al. (2015) Functional analysis of free fatty acid receptor GPR120 in human eosinophils: implications in metabolic homeostasis. PLoS One 10:e120386.

Koole C, Savage EE, Christopoulos A, Miller LJ, Sexton PM, and Wootten D (2013) Minireview: signal bias, allosterism, and polymorphic variation at the GLP-1R implications for drug discovery. Mol Endocrinol 27:1234-1244.

Koole C, Wootten D, Simms J, Valant C, Sridhar R, Woodman OL, Miller LJ, Summers RJ, Christopoulos A, and Sexton PM (2010) Allosteric ligands of the glucagon-like peptide 1 receptor (GLP-1R) differentially modulate endogenous and exogenous peptide responses in a pathway-selective manner: implications for drug screening. Mol Pharmacol 78:456-465.

Kraakman MJ, Murphy AJ, Jandeleit-Dahm K, and Kammoun HL (2014) Macrophage polarization in obesity and type 2 diabetes: weighing down our understanding of macrophage function. Front Immunol 5:470.

Krieger J-P, Arnold M, Pettersen KG, Lossel P, Langhans W, and Lee SJ (2016) Knockdown of GLP-1 receptors in vagal afferents affects normal food intake and glycemia. Diabetes 65:34-43.

Krinninger P, Ensenauer R, Ehlers K, Rauh K, Stoll J, Krauss-Etschmann S, Hauner $\mathrm{H}$, and Laumen $\mathrm{H}$ (2014) Peripheral monocytes of obese women display increased chemokine receptor expression and migration capacity. J Clin Endocrinol Metab 99:2500-2509.

Ku GM, Pappalardo Z, Luo CC, German MS, and McManus MT (2012) An siRNA screen in pancreatic beta cells reveals a role for Gpr27 in insulin production. PLoS Genet 8:e1002449.

Kumar R, Balhuizen A, Amisten S, Lundquist I, and Salehi A (2011) Insulinotropic and antidiabetic effects of $17 \beta$-estradiol and the GPR30 agonist G-1 on human pancreatic islets. Endocrinology 152:2568-2579.

Kurabayashi N, Nguyen MD, and Sanada K (2013) The G protein-coupled receptor GPRC5B contributes to neurogenesis in the developing mouse neocortex. Development 140:4335-4346.

Kusminski CM, Bickel PE, and Scherer PE (2016) Targeting adipose tissue in the treatment of obesity-associated diabetes. Nat Rev Drug Discov 15:639-660.

Lafontan M, Piazza PV, and Girard J (2007) Effects of CB1 antagonist on the control of metabolic functions in obese type 2 diabetic patients. Diabetes Metab 33:85-95.

Lane JM, Chang A-M, Bjonnes AC, Aeschbach D, Anderson C, Cade BE, Cain SW, Czeisler CA, Gharib SA, Gooley JJ, et al. (2016) Impact of common diabetes risk variant in MTNR1B on sleep, circadian, and melatonin physiology. Diabetes 65 1741-1751.

Lauffer LM, Iakoubov R, and Brubaker PL (2009) GPR119 is essential for oleoylethanolamide-induced glucagon-like peptide-1 secretion from the intestinal enteroendocrine L-cell. Diabetes 58:1058-1066.

Lee B-C and Lee J (2014) Cellular and molecular players in adipose tissue inflammation in the development of obesity-induced insulin resistance. Biochim Biophys Acta 1842:446-462.

Lee NK, Sowa H, Hinoi E, Ferron M, Ahn JD, Confavreux C, Dacquin R, Mee PJ, McKee MD, Jung DY, et al. (2007) Endocrine regulation of energy metabolism by the skeleton. Cell 130:456-469.

Lee T, Schwandner R, Swaminath G, Weiszmann J, Cardozo M, Greenberg J, Jaeckel $\mathrm{P}$, Ge H, Wang Y, Jiao X, et al. (2008) Identification and functional characterization of allosteric agonists for the G protein-coupled receptor FFA2. Mol Pharmacol $\mathbf{7 4}$ 1599-1609.

Lefebvre E, Moyle G, Reshef R, Richman LP, Thompson M, Hong F, Chou HL, Hashiguchi T, Plato C, Poulin D, et al. (2016) Antifibrotic effects of the dual CCR2 CCR5 antagonist cenicriviroc in animal models of liver and kidney fibrosis. PLoS One 11:e158156.

Leonard S, Kinsella GK, Benetti E, and Findlay JBC (2016) Regulating the effects of GPR21, a novel target for type 2 diabetes. Sci Rep 6:27002

$\mathrm{Li} \mathrm{A}, \mathrm{Li}$ Y, and Du L (2015a) Biological characteristics and agonists of GPR120 (FFAR4) receptor: the present status of research. Future Med Chem 7:1457-1468

Li P, Oh DY, Bandyopadhyay G, Lagakos WS, Talukdar S, Osborn O, Johnson A Chung H, Maris M, Ofrecio JM, et al. (2015b) LTB4 promotes insulin resistance in obese mice by acting on macrophages, hepatocytes and myocytes. Nat Med 21: 239-247.

Li X, Zhong K, Guo Z, Zhong D, and Chen X (2015c) Fasiglifam (TAK-875) inhibits hepatobiliary transporters: a possible factor contributing to fasiglifam-induced liver injury. Drug Metab Dispos 43:1751-1759.

Liggett SB (2009) alpha2A-adrenergic receptors in the genetics, pathogenesis, and treatment of type 2 diabetes. Sci Transl Med 1:12ps15.

Limbird LE (1988) Receptors linked to inhibition of adenylate cyclase: additional signaling mechanisms. FASEB J 2:2686-2695.

Lin DCH, Guo Q, Luo J, Zhang J, Nguyen K, Chen M, Tran T, Dransfield PJ, Brown SP, Houze J, et al. (2012) Identification and pharmacological characterization of multiple allosteric binding sites on the free fatty acid 1 receptor. Mol Pharmacol 82:843-859.

Lin Y and Sun Z (2010) Current views on type 2 diabetes, $J$ Endocrinol 204:1-11.

Littlewood-Evans A, Sarret S, Apfel V, Loesle P, Dawson J, Zhang J, Muller A, Tigani B, Kneuer R, Patel S, et al. (2016) GPR91 senses extracellular succinate released from inflammatory macrophages and exacerbates rheumatoid arthritis. $J$ Exp Med 213:1655-1662.

Liu B, Song S, Jones PM, and Persaud SJ (2015a) GPR55: from orphan to metabolic regulator? Pharmacol Ther 145:35-42.

Liu HD, Wang WB, Xu ZG, Liu CH, He DF, Du LP, Li MY, Yu X, and Sun JP (2015b) FFA4 receptor (GPR120): a hot target for the development of anti-diabetic therapies. Eur J Pharmacol 763 (Pt B):160-168.

Liu J, Ibi D, Taniguchi K, Lee J, Herrema H, Akosman B, Mucka P, Salazar Hernandez MA, Uyar MF, Park SW, et al. (2016) Inflammation improves glucose homeostasis through IKKß-XBP1s interaction. Cell 167:1052-1066.e18.

Liu P, Hu Z, DuBois BG, Moyes CR, Hunter DN, Zhu C, Kar NF, Zhu Y, Garfunkle J, Kang L, et al. (2015c) Design of potent and orally active GPR119 agonists for the treatment of type II diabetes. ACS Med Chem Lett 6:936-941.

Lizarzaburu M, Turcotte S, Du X, Duquette J, Fu A, Houze J, Li L, Liu J, Murakoshi M, Oda K, et al. (2012) Discovery and optimization of a novel series of GPR142 agonists for the treatment of type 2 diabetes mellitus. Bioorg Med Chem Lett 22:5942-5947.

Lyssenko V, Nagorny CLF, Erdos MR, Wierup N, Jonsson A, Spégel P, Bugliani M, Saxena R, Fex M, Pulizzi N, et al. (2009) Common variant in MTNR1B associated with increased risk of type 2 diabetes and impaired early insulin secretion. Nat Genet 41:82-88.

Mackenzie AE, Lappin JE, Taylor DL, Nicklin SA, and Milligan G (2011) GPR35 as a novel therapeutic target. Front Endocrinol (Lausanne) 2:68.

Madeddu S, Woods TA, Mukherjee P, Sturdevant D, Butchi NB, and Peterson KE (2015) Identification of glial activation markers by comparison of transcriptome changes between astrocytes and microglia following innate immune stimulation. PLoS One 10:e127336.

Mancini AD and Poitout V (2013) The fatty acid receptor FFA1/GPR40 a decade later: how much do we know? Trends Endocrinol Metab 24:398-407.

Mancini AD and Poitout V (2015) GPR40 agonists for the treatment of type 2 diabetes: life after 'taking' a hit. Diabetes Obes Metab 17:622-629.

Maravillas-Montero JL, Burkhardt AM, Hevezi PA, Carnevale CD, Smit MJ, and Zlotnik A (2015) Cutting edge: GPR35/CXCR8 is the receptor of the mucosal chemokine CXCL17. J Immunol 194:29-33.

Marso SP, Bain SC, Consoli A, Eliaschewitz FG, Jódar E, Leiter LA, Lingvay I, Rosenstock J, Seufert J, Warren ML, et al.; SUSTAIN-6 Investigators (2016) Semaglutide and cardiovascular outcomes in patients with type 2 diabetes. $N$ Engl J Med 375:1834-1844

Mårtensson UEA, Salehi SA, Windahl S, Gomez MF, Swärd K, Daszkiewicz-Nilsson J, Wendt A, Andersson N, Hellstrand P, Grände PO, et al. (2009) Deletion of the G protein-coupled receptor 30 impairs glucose tolerance, reduces bone growth, increases blood pressure, and eliminates estradiol-stimulated insulin release in female mice. Endocrinology 150:687-698.

Mazzola N (2012) Review of current and emerging therapies in type 2 diabetes mellitus. Am J Manag Care 18(1 Suppl):S17-S26.

McCreath KJ, Espada S, Gálvez BG, Benito M, de Molina A, Sepúlveda $\mathrm{P}$, and Cervera AM (2015) Targeted disruption of the SUCNR1 metabolic receptor leads to dichotomous effects on obesity. Diabetes 64:1154-1167.

McKenzie CI, Mackay CR, and Macia L (2015) GPR43: a prototypic metabolite sensor linking metabolic and inflammatory diseases. Trends Endocrinol Metab 26:511-512. 
McKillop AM, Moran BM, Abdel-Wahab YHA, and Flatt PR (2013) Evaluation of the insulin releasing and antihyperglycaemic activities of GPR55 lipid agonists using clonal beta-cells, isolated pancreatic islets and mice. Br J Pharmacol 170:978-990.

McMullan CJ, Schernhammer ES, Rimm EB, Hu FB, and Forman JP (2013) Melatonin secretion and the incidence of type 2 diabetes. JAMA 309:1388-1396.

Meadows A, Lee JH, Wu C-S, Wei Q, Pradhan G, Yafi M, Lu HC, and Sun Y (2015) Deletion of G-protein-coupled receptor 55 promotes obesity by reducing physical activity. Int $J$ Obes 40:417-424

Meier JJ (2012) GLP-1 receptor agonists for individualized treatment of type 2 diabetes mellitus. Nat Rev Endocrinol 8:728-742.

Meister J, Le Duc D, Ricken A, Burkhardt R, Thiery J, Pfannkuche H, Polte T, Grosse J, Schöneberg T, and Schulz A (2014) The G protein-coupled receptor P2Y14 influences insulin release and smooth muscle function in mice. J Biol Chem 289 : 23353-23366.

Menne J, Eulberg D, Beyer D, Baumann M, Saudek F, Valkusz Z, Więcek A and Haller H; Emapticap Study Group (2017) C-C motif-ligand 2 inhibition with emapticap pegol (NOX-E36) in type 2 diabetic patients with albuminuria. Nephrol Dial Transplant 32:307-315

Michel MC and Gravas S (2016) Safety and tolerability of $\beta 3$-adrenoceptor agonists in the treatment of overactive bladder syndrome: insight from transcriptosome and experimental studies. Expert Opin Drug Saf 15:647-657.

Michelotti GA, Machado MV, and Diehl AM (2013) NAFLD, NASH and liver cancer. Nat Rev Gastroenterol Hepatol 10:656-665.

Milligan G (2011) Orthologue selectivity and ligand bias: translating the pharmacology of GPR35. Trends Pharmacol Sci 32:317-325.

Milligan G, Shimpukade B, Ulven T, and Hudson BD (2017) Complex pharmacology of free fatty acid receptors. Chem Rev 117:67-110.

Milligan G, Stoddart LA, and Smith NJ (2009) Agonism and allosterism: the pharmacology of the free fatty acid receptors FFA2 and FFA3. $\mathrm{Br} J$ Pharmacol 158: $146-153$.

Mittermayer F, Caveney E, De Oliveira C, Gourgiotis L, Puri M, Tai LJ, and Turner JR (2015) Addressing unmet medical needs in type 2 diabetes: a narrative review of drugs under development. Curr Diabetes Rev 11:17-31.

Mizokami A, Yasutake Y, Gao J, Matsuda M, Takahashi I, Takeuchi H, and Hirata M (2013) Osteocalcin induces release of glucagon-like peptide-1 and thereby stimulates insulin secretion in mice. PLoS One 8:e57375.

Moody TW, Ito T, Osefo N, and Jensen RT (2011) VIP and PACAP: recent insights into their functions/roles in physiology and disease from molecular and genetic studies. Curr Opin Endocrinol Diabetes Obes 18:61-67.

Morino K, Petersen KF, and Shulman GI (2006) Molecular mechanisms of insulin resistance in humans and their potential links with mitochondrial dysfunction. Diabetes 55 (Suppl 2):S9-S15.

Mueckler MM (1992) The molecular biology of mammalian glucose transporters. Curr Opin Nephrol Hypertens 1:12-20.

Müller MM, Lehmann R, Klassert TE, Reifenstein S, Conrad T, Moore C, Kuhn A, Behnert A, Guthke R, Driesch D, et al. (2017) Global analysis of glycoproteins identifies markers of endotoxin tolerant monocytes and GPR84 as a modulator of TNF $\alpha$ expression. Sci Rep 7:838.

Murakoshi M, Kuwabara H, Nagasaki M, Xiong YM, Reagan JD, Maeda H, and Nara F (2016) Discovery and pharmacological effects of a novel GPR142 antagonist. J Recept Signal Transduct Res 37:290-296.

Nagasaki H, Kondo T, Fuchigami M, Hashimoto H, Sugimura Y, Ozaki N, Arima H, Ota A, Oiso Y, and Hamada Y (2012) Inflammatory changes in adipose tissue enhance expression of GPR84, a medium-chain fatty acid receptor: TNF $\alpha$ enhances GPR84 expression in adipocytes. FEBS Lett 586:368-372.

Nam DH, Lee MH, Kim JE, Song HK, Kang YS, Lee JE, Kim HW, Cha JJ, Hyun YY, Kim SH, et al. (2012) Blockade of cannabinoid receptor 1 improves insulin resistance, lipid metabolism, and diabetic nephropathy in $\mathrm{db} / \mathrm{db}$ mice. Endocrinology 153:1387-1396

Nedergaard J, Bengtsson T, and Cannon B (2007) Unexpected evidence for active brown adipose tissue in adult humans. Am J Physiol Endocrinol Metab 293: E444-E452.

Nedergaard J and Cannon B (2014) The browning of white adipose tissue: some burning issues. Cell Metab 20:396-407.

Németh B, Doczi J, Csete D, Kacso G, Ravasz D, Adams D, Kiss G, Nagy AM, Horvath G, Tretter L, et al. (2016) Abolition of mitochondrial substrate-level phosphorylation by itaconic acid produced by LPS-induced Irg1 expression in cells of murine macrophage lineage. FASEB J 30:286-300.

Neuman JC and Kimple ME (2013) The EP3 receptor: exploring a new target for type 2 diabetes therapeutics. J Endocrinol Diabetes Obes 1:1002.

Neuman JC, Schaid MD, Brill AL, Fenske RJ, Kibbe CR, Fontaine DA, Sdao SM, Brar HK, Connors KM, Wienkes HN, et al. (2017) Enriching islet phospholipids with eicosapentaenoic acid reduces prostaglandin E2 signaling and enhances diabetic $\beta$-cell function. Diabetes 66:1572-1585.

Nevzorova J, Bengtsson T, Evans BA, and Summers RJ (2002) Characterization of the beta-adrenoceptor subtype involved in mediation of glucose transport in L6 cells. Br J Pharmacol 137:9-18.

Nevzorova J, Evans BA, Bengtsson T, and Summers RJ (2006) Multiple signalling pathways involved in beta2-adrenoceptor-mediated glucose uptake in rat skeletal muscle cells. Br J Pharmacol 147:446-454.

Nøhr MK, Pedersen MH, Gille A, Egerod KL, Engelstoft MS, Husted AS, Sichlau RM, Grunddal KV, Poulsen SS, Han S, et al. (2013) GPR41/FFAR3 and GPR43/FFAR2 as cosensors for short-chain fatty acids in enteroendocrine cells vs FFAR3 in enteric neurons and FFAR2 in enteric leukocytes. Endocrinology 154:3552-3564.

Nolte WM, Fortin J-P, Stevens BD, Aspnes GE, Griffith DA, Hoth LR, Ruggeri RB, Mathiowetz AM, Limberakis C, Hepworth D, et al. (2014) A potentiator of orthosteric ligand activity at GLP-1R acts via covalent modification. Nat Chem Biol 10:629-631.

Nunez DJ, Bush MA, Collins DA, McMullen SL, Gillmor D, Apseloff G, Atiee G, Corsino L, Morrow L, and Feldman PL (2014) Gut hormone pharmacology of a novel GPR119 agonist (GSK1292263), metformin, and sitagliptin in type 2 diabetes mellitus: results from two randomized studies. PLoS One 9:e92494.

O'Connell TD, Jensen BC, Baker AJ, and Simpson PC (2013) Cardiac alpha1adrenergic receptors: novel aspects of expression, signaling mechanisms, physiologic function, and clinical importance. Pharmacol Rev 66:308-333.

Odori S, Hosoda K, Tomita T, Fujikura J, Kusakabe T, Kawaguchi Y, Doi R, Takaori K, Ebihara K, Sakai Y, et al. (2013) GPR119 expression in normal human tissues and islet cell tumors: evidence for its islet-gastrointestinal distribution, expression in pancreatic beta and alpha cells, and involvement in islet function. Metabolism 62:70-78.

Oh DY, Talukdar S, Bae EJ, Imamura T, Morinaga H, Fan W, Li P, Lu WJ, Watkins SM, and Olefsky JM (2010) GPR120 is an omega-3 fatty acid receptor mediating potent anti-inflammatory and insulin-sensitizing effects. Cell 142:687-698

Oh DY, Walenta E, Akiyama TE, Lagakos WS, Lackey D, Pessentheiner AR, Sasik R, Hah N, Chi TJ, Cox JM, et al. (2014) A Gpr120-selective agonist improves insulin resistance and chronic inflammation in obese mice. Nat Med 20:942-947.

Olefsky JM and Glass CK (2010) Macrophages, inflammation, and insulin resistance. Annu Rev Physiol 72:219-246.

Ortiz-Alonso FJ, Herman WH, Gertz BJ, Williams VC, Smith MJ, and Halter JB (1991) Effect of an oral alpha 2-adrenergic blocker (MK-912) on pancreatic islet function in non-insulin-dependent diabetes mellitus. Metabolism 40:1160-1167.

Osborn O, Oh DY, McNelis J, Sanchez-Alavez M, Talukdar S, Lu M, Li P, Thiede L, Morinaga H, Kim JJ, et al. (2012) G protein-coupled receptor 21 deletion improves insulin sensitivity in diet-induced obese mice. J Clin Invest 122:2444-2453.

Osborn O and Olefsky JM (2012) The cellular and signaling networks linking the immune system and metabolism in disease. Nat Med 18:363-374.

Ostenson CG, Pigon J, Doxey JC, and Efendic S (1988) Alpha 2-adrenoceptor blockade does not enhance glucose-induced insulin release in normal subjects or patients with noninsulin-dependent diabetes. $J$ Clin Endocrinol Metab 67: $1054-1059$

Otto C, Rohde-Schulz B, Schwarz G, Fuchs I, Klewer M, Brittain D, Langer G, Bader B, Prelle K, Nubbemeyer R, et al. (2008) G protein-coupled receptor 30 localizes to the endoplasmic reticulum and is not activated by estradiol. Endocrinology 149: $4846-4856$

Oury F, Ferron M, Huizhen W, Confavreux C, Xu L, Lacombe J, Srinivas P, Chamouni A, Lugani F, Lejeune H, et al. (2013) Osteocalcin regulates murine and human fertility through a pancreas-bone-testis axis. J Clin Invest 123:2421-2433.

Oury F, Sumara G, Sumara O, Ferron M, Chang H, Smith CE, Hermo L, Suarez S, Roth BL, Ducy P, et al. (2011) Endocrine regulation of male fertility by the skeleton. Cell 144:796-809.

Panaro BL, Flock GB, Campbell JE, Beaudry JL, Cao X, and Drucker DJ (2017) $\beta$-Cell inactivation of Gpr119 unmasks incretin dependence of GPR119-mediated glucoregulation. Diabetes 66:1626-1635.

Perley MJ and Kipnis DM (1967) Plasma insulin responses to oral and intravenous glucose: studies in normal and diabetic sujbjects. J Clin Invest 46:1954-1962.

Pi M, Chen L, Huang MZ, Zhu W, Ringhofer B, Luo J, Christenson L, Li B, Zhang J, Jackson PD, et al. (2008) GPRC6A null mice exhibit osteopenia, feminization and metabolic syndrome. PLoS One 3:e3858.

Pi M, Kapoor K, Ye R, Nishimoto SK, Smith JC, Baudry J, and Quarles LD (2016) Evidence for osteocalcin binding and activation of GPRC6A in $\beta$-cells. Endocrinology 157:1866-1880.

Pi M and Quarles LD (2012) GPRC6A regulates prostate cancer progression. Prostate 72:399-409.

Pi M, Wu Y, Lenchik NI, Gerling I, and Quarles LD (2012) GPRC6A mediates the effects of L-arginine on insulin secretion in mouse pancreatic islets. Endocrinology 153:4608-4615

Pi M, Wu Y, and Quarles LD (2011) GPRC6A mediates responses to osteocalcin in $\beta$-cells in vitro and pancreas in vivo. J Bone Miner Res 26:1680-1683.

Piascik MT and Perez DM (2001) Alpha1-adrenergic receptors: new insights and directions. J Pharmacol Exp Ther 298:403-410.

Plaisance EP, Lukasova M, Offermanns S, Zhang Y, Cao G, and Judd RL (2009) Niacin stimulates adiponectin secretion through the GPR109A receptor. Am $J$ Physiol Endocrinol Metab 296:E549-E558.

Popa SM, Clifton DK, and Steiner RA (2008) The role of kisspeptins and GPR54 in the neuroendocrine regulation of reproduction. Annu Rev Physiol 70:213-238.

Pratley RE, Nauck MA, Barnett AH, Feinglos MN, Ovalle F, Harman-Boehm I, Ye J, Scott R, Johnson S, Stewart M, et al.; HARMONY 7 Study Group (2014) Onceweekly albiglutide versus once-daily liraglutide in patients with type 2 diabetes inadequately controlled on oral drugs (HARMONY 7): a randomised, open-label, multicentre, non-inferiority phase 3 study. Lancet Diabetes Endocrinol 2:289-297.

Prentki M and Nolan CJ (2006) Islet beta cell failure in type 2 diabetes. J Clin Invest 116:1802-1812.

Prokopenko I, Langenberg C, Florez JC, Saxena R, Soranzo N, Thorleifsson G, Loos RJ, Manning AK, Jackson AU, Aulchenko Y, et al. (2009) Variants in MTNR1B influence fasting glucose levels. Nat Genet 41:77-81.

Raun K, von Voss P, Gotfredsen CF, Golozoubova V, Rolin B, and Knudsen LB (2007) Liraglutide, a long-acting glucagon-like peptide-1 analog, reduces body weight and food intake in obese candy-fed rats, whereas a dipeptidyl peptidase-IV inhibitor, vildagliptin, does not. Diabetes 56:8-15.

Regard JB, Sato IT, and Coughlin SR (2008) Anatomical profiling of G proteincoupled receptor expression. Cell 135:561-571.

Renström F, Koivula RW, Varga TV, Hallmans G, Mulder H, Florez JC, Hu FB, and Franks PW (2015) Season-dependent associations of circadian rhythmregulating loci (CRY1, CRY2 and MTNR1B) and glucose homeostasis: the GLACIER Study. Diabetologia 58:997-1005.

Ritter K, Buning C, Halland N, Pöverlein C, and Schwink L (2016) G protein-coupled receptor 119 (GPR119) agonists for the treatment of diabetes: recent progress and prevailing challenges. $J$ Med Chem 59:3579-3592.

Robbins MJ, Michalovich D, Hill J, Calver AR, Medhurst AD, Gloger I, Sims M Middlemiss DN, and Pangalos MN (2000) Molecular cloning and characterization 
of two novel retinoic acid-inducible orphan G-protein-coupled receptors (GPRC5B and GPRC5C). Genomics 67:8-18.

Rohrbach K, Thomas MA, Glick S, Fung EN, Wang V, Watson L, Gregory P, Antel J, and Pelleymounter MA (2012) Ibipinabant attenuates $\beta$-cell loss in male Zucker diabetic fatty rats independently of its effects on body weight. Diabetes Obes Metab 14:555-564.

Rönn T, Wen J, Yang Z, Lu B, Du Y, Groop L, Hu R, and Ling C (2009) A common variant in MTNR1B, encoding melatonin receptor $1 \mathrm{~B}$, is associated with type 2 diabetes and fasting plasma glucose in Han Chinese individuals. Diabetologia $\mathbf{5 2}$ 830-833.

Rosengren AH, Jokubka R, Tojjar D, Granhall C, Hansson O, Li DQ, Nagaraj V, Reinbothe TM, Tuncel J, Eliasson L, et al. (2010) Overexpression of alpha2Aadrenergic receptors contributes to type 2 diabetes. Science 327:217-220.

Ross RA (2009) The enigmatic pharmacology of GPR55. Trends Pharmacol Sci 30: $156-163$

Rossol M, Pierer M, Raulien N, Quandt D, Meusch U, Rothe K, Schubert K, Schöneberg T, Schaefer M, Krügel U, et al. (2012) Extracellular $\mathrm{Ca}^{2+}$ is a danger signal activating the NLRP3 inflammasome through G protein-coupled calcium sensing receptors. Nat Commun 3:1329.

Roth Flach RJ, Matevossian A, Akie TE, Negrin KA, Paul MT, and Czech MP (2013) B3-Adrenergic receptor stimulation induces E-selectin-mediated adipose tissue inflammation. J Biol Chem 288:2882-2892.

Roth JD, Erickson MR, Chen S, and Parkes DG (2012) GLP-1R and amylin agonism in metabolic disease: complementary mechanisms and future opportunities. $\mathrm{Br} J$ Pharmacol 166:121-136.

Rubic T, Lametschwandtner G, Jost S, Hinteregger S, Kund J, Carballido-Perrig N, Schwärzler C, Junt T, Voshol H, Meingassner JG, et al. (2008) Triggering the succinate receptor GPR91 on dendritic cells enhances immunity. Nat Immunol $\mathbf{9}$ 1261-1269.

Rueda P, Harley E, Lu Y, Stewart GD, Fabb S, Diepenhorst N, Cremers B, Rouillon MH, Wehrle I, Geant A, et al. (2016) Murine GPRC6A mediates cellular responses to L-amino acids, but not osteocalcin variants. PLoS One 11:e0146846.

Salcedo I, Tweedie D, Li Y, and Greig NH (2012) Neuroprotective and neurotrophic actions of glucagon-like peptide-1: an emerging opportunity to treat neurodegenerative and cerebrovascular disorders. Br J Pharmacol 166:1586-1599.

Samuel VT and Shulman GI (2012) Mechanisms for insulin resistance: common threads and missing links. Cell 148:852-871.

Sato M, Dehvari N, Oberg AI, Dallner OS, Sandström AL, Olsen JM, Csikasz RI, Summers RJ, Hutchinson DS, and Bengtsson T (2014) Improving type 2 diabetes through a distinct adrenergic signaling pathway involving mTORC2 that mediates glucose uptake in skeletal muscle. Diabetes 63:4115-4129.

Scheen AJ (2007) Cannabinoid-1 receptor antagonists in type-2 diabetes. Best Pract Res Clin Endocrinol Metab 21:535-553.

Scheer FAJL, Hilton MF, Mantzoros CS, and Shea SA (2009) Adverse metabolic and cardiovascular consequences of circadian misalignment. Proc Natl Acad Sci USA 106:4453-4458

Schmidt J, Smith NJ, Christiansen E, Tikhonova IG, Grundmann M, Hudson BD, Ward RJ, Drewke C, Milligan G, Kostenis E, et al. (2011) Selective orthosteric free fatty acid receptor 2 (FFA2) agonists: identification of the structural and chemical requirements for selective activation of FFA2 versus FFA3. J Biol Chem 286 10628-10640.

Schroder K, Zhou R, and Tschopp J (2010) The NLRP3 inflammasome: a sensor for metabolic danger? Science 327:296-300.

Secher A, Jelsing J, Baquero AF, Hecksher-Sørensen J, Cowley MA, Dalbøge LS, Hansen G, Grove KL, Pyke C, Raun K, et al. (2014) The arcuate nucleus mediate GLP-1 receptor agonist liraglutide-dependent weight loss. $J$ Clin Invest 124 $4473-4488$

Sennitt MV, Arch JR, Levy AL, Simson DL, Smith SA, and Cawthorne MA (1985) Anti-hyperglycaemic action of BRL 26830, a novel beta-adrenoceptor agonist, in mice and rats. Biochem Pharmacol 34:1279-1285.

Sharma G, Hu C, Brigman JL, Zhu G, Hathaway HJ, and Prossnitz ER (2013) GPER deficiency in male mice results in insulin resistance, dyslipidemia, and a proinflammatory state. Endocrinology 154:4136-4145.

Sharma G, Mauvais-Jarvis F, and Prossnitz ER (2017) Roles of G protein-coupled estrogen receptor GPER in metabolic regulation. J Steroid Biochem Mol Biol DOI: 10.1016/j.jsbmb.2017.02.012 [published ahead of print].

Shehata MA, Christensen HB, Isberg V, Pedersen DS, Bender A, Bräuner-Osborne H, Shehata MA, Pedersen DS, and Gloriam DE (2015) Identification of the first surrogate agonists for the G protein-coupled receptor GPR132. RSC Advances 5 $48551-48557$.

Shi C and Pamer EG (2011) Monocyte recruitment during infection and inflammation. Nat Rev Immunol 11:762-774.

Shi T, Papay RS, and Perez DM (2016) $\alpha 1 \mathrm{~A}$-Adrenergic receptor prevents cardiac ischemic damage through PKC6/GLUT1/4-mediated glucose uptake. J Recept Signal Transduct Res 36:261-270.

Shore DM and Reggio PH (2015) The therapeutic potential of orphan GPCRs, GPR35 and GPR55. Front Pharmacol 6:69.

Shu CJ, Benoist C, and Mathis D (2012) The immune system's involvement in obesity-driven type 2 diabetes. Semin Immunol 24:436-442.

Shulman GI (2000) Cellular mechanisms of insulin resistance. $J$ Clin Invest 106: 171-176.

Simcocks AC, O’Keefe L, Jenkin KA, Mathai ML, Hryciw DH, and McAinch AJ (2014) A potential role for GPR55 in the regulation of energy homeostasis. Drug Discov Today 19:1145-1151.

Sina C, Gavrilova O, Förster M, Till A, Derer S, Hildebrand F, Raabe B, Chalaris A Scheller J, Rehmann A, et al. (2009) G protein-coupled receptor 43 is essential for neutrophil recruitment during intestinal inflammation. J Immunol 183:7514-7522.

Sisley S, Gutierrez-Aguilar R, Scott M, D'Alessio DA, Sandoval DA, and Seeley RJ (2014) Neuronal GLP1R mediates liraglutide's anorectic but not glucose-lowering effect. J Clin Invest 124:2456-2463.
Smajilovic S, Clemmensen C, Johansen LD, Wellendorph P, Holst JJ, Thams PG, Ogo E, and Bräuner-Osborne $\mathrm{H}$ (2013) The L- $\alpha$-amino acid receptor GPRC6A is expressed in the islets of Langerhans but is not involved in L-arginine-induced insulin release. Amino Acids 44:383-390.

Smith LL, Mosley JF II, Parke C, Brown J, Barris LS, and Phan LD (2016) Dulaglutide (Trulicity): the third once-weekly GLP-1 agonist. $P \& T$ 41:357-360.

Smith NJ, Ward RJ, Stoddart LA, Hudson BD, Kostenis E, Ulven T, Morris JC, Tränkle C, Tikhonova IG, Adams DR, et al. (2011) Extracellular loop 2 of the free fatty acid receptor 2 mediates allosterism of a phenylacetamide ago-allosteric modulator. Mol Pharmacol 80:163-173.

Song G, Yang D, Wang Y, de Graaf C, Zhou Q, Jiang S, Liu K, Cai X, Dai A, Lin G, et al. (2017) Human GLP-1 receptor transmembrane domain structure in complex with allosteric modulators. Nature 546:312-315.

Soni A, Amisten S, Rorsman P, and Salehi A (2013) GPRC5B a putative glutamatereceptor candidate is negative modulator of insulin secretion. Biochem Biophys Res Commun 441:643-648.

Speliotes EK, Willer CJ, Berndt SI, Monda KL, Thorleifsson G, Jackson AU, Lango Allen H, Lindgren CM, Luan J, Mägi R, et al.; MAGIC; ; Procardis Consortium (2010) Association analyses of 249,796 individuals reveal 18 new loci associated with body mass index. Nat Genet 42:937-948.

Spite M, Hellmann J, Tang Y, Mathis SP, Kosuri M, Bhatnagar A, Jala VR, and Haribabu B (2011) Deficiency of the leukotriene B4 receptor, BLT-1, protects against systemic insulin resistance in diet-induced obesity. J Immunol 187:1942-1949.

Sprecher D, Maxwell M, Goodman J, White B, Tang CMM, Boullay V, and de Gouville AC (2015) Discovery and characterization of GSK256073, a non-flushing hydroxy-carboxylic acid receptor 2 (HCA2) agonist. Eur J Pharmacol 756:1-7.

Srivastava A, Yano J, Hirozane Y, Kefala G, Gruswitz F, Snell G, Lane W, Ivetac A Aertgeerts K, Nguyen J, et al. (2014) High-resolution structure of the human GPR40 receptor bound to allosteric agonist TAK-875. Nature 513:124-127.

Stone VM, Dhayal S, Brocklehurst KJ, Lenaghan C, Sörhede Winzell M, Hammar M, $\mathrm{Xu}$ X, Smith DM, and Morgan NG (2014) GPR120 (FFAR4) is preferentially expressed in pancreatic delta cells and regulates somatostatin secretion from murine islets of Langerhans. Diabetologia 57:1182-1191.

Sullivan T, Miao Z, Dairaghi DJ, Krasinski A, Wang Y, Zhao BN, Baumgart T, Ert LS, Pennell A, Seitz L, et al. (2013b) CCR2 antagonist CCX140-B provides renal and glycemic benefits in diabetic transgenic human CCR2 knockin mice. Am J Physiol Renal Physiol 305:F1288-F1297.

Sullivan TJ, Miao Z, Zhao BN, Ertl LS, Wang Y, Krasinski A, Walters MJ, Powers JP, Dairaghi DJ, Baumgart T, et al. (2013a) Experimental evidence for the use of CCR2 antagonists in the treatment of type 2 diabetes. Metabolism 62:1623-1632. Suzuki M, Takaishi S, Nagasaki M, Onozawa Y, Iino I, Maeda H, Komai T, and Oda T (2013) Medium-chain fatty acid-sensing receptor, GPR84, is a proinflammatory receptor. J Biol Chem 288:10684-10691.

Tager AM and Luster AD (2003) BLT1 and BLT2: the leukotriene B(4) receptors. Prostaglandins Leukot Essent Fatty Acids 69:123-134.

Talukdar S, Olefsky JM, and Osborn O (2011) Targeting GPR120 and other fatty acid-sensing GPCRs ameliorates insulin resistance and inflammatory diseases. Trends Pharmacol Sci 32:543-550.

Tang C, Ahmed K, Gille A, Lu S, Gröne HJ, Tunaru S, and Offermanns S (2015) Loss of FFA2 and FFA3 increases insulin secretion and improves glucose tolerance in type 2 diabetes. Nat Med 21:173-177.

Tanti J-F, Ceppo F, Jager J, and Berthou F (2013) Implication of inflammatory signaling pathways in obesity-induced insulin resistance. Front Endocrinol (Lausanne) 3:181.

Thorburn AN, Macia L, and Mackay CR (2014) Diet, metabolites, and "westernlifestyle" inflammatory diseases. Immunity 40:833-842.

Tian L, Gao J, Weng G, Yi H, Tian B, O’Brien TD, and Guo Z (2011) Comparison of exendin- 4 on beta-cell replication in mouse and human islet grafts. Transpl Int 24: 856-864.

Tian R and Abel ED (2001) Responses of GLUT4-deficient hearts to ischemia underscore the importance of glycolysis. Circulation 103:2961-2966.

Toda N, Hao X, Ogawa Y, Oda K, Yu M, Fu Z, Chen Y, Kim Y, Lizarzaburu M, Lively S, et al. (2013) Potent and orally bioavailable GPR142 agonists as novel insulin secretagogues for the treatment of type 2 diabetes. ACS Med Chem Lett 4:790-794.

Trujillo JM, Nuffer W, and Ellis SL (2015) GLP-1 receptor agonists: a review of headto-head clinical studies. Ther Adv Endocrinol Metab 6:19-28.

Tsou C-L, Peters W, Si Y, Slaymaker S, Aslanian AM, Weisberg SP, Mack M, and Charo IF (2007) Critical roles for CCR2 and MCP-3 in monocyte mobilization from bone marrow and recruitment to inflammatory sites. $J$ Clin Invest 117: 902-909.

Tuomi T, Nagorny CLF, Singh P, Bennet H, Yu Q, Alenkvist I, Isomaa B, Östman B, Söderström J, Pesonen AK, et al. (2016) Increased melatonin signaling is a risk factor for type 2 diabetes. Cell Metab 23:1067-1077.

Ulven T (2012) Short-chain free fatty acid receptors FFA2/GPR43 and FFA3/GPR41 as new potential therapeutic targets. Front Endocrinol (Lausanne) 3:111.

Ulven T and Christiansen E (2015) Dietary fatty acids and their potential for controlling metabolic diseases through activation of FFA4/GPR120. Annu Rev Nutr 35: $239-263$

van Bloemendaal L, Ten Kulve JS, la Fleur SE, Ijzerman RG, and Diamant M (2014) Effects of glucagon-like peptide 1 on appetite and body weight: focus on the CNS. $J$ Endocrinol 221:T1-T16.

Van den Bossche J, O'Neill LA, and Menon D (2017) Macrophage immunometabolism: where are we (going)? Trends Immunol 38:395-406.

van Diepen JA, Robben JH, Hooiveld GJ, Carmone C, Alsady M, Boutens L, Bekkenkamp-Grovenstein M, Hijmans A, Engelke UFH, Wevers RA, et al. (2017) SUCNR1-mediated chemotaxis of macrophages aggravates obesity-induced in flammation and diabetes. Diabetologia 60:1304-1313.

Vandanmagsar B, Youm Y-H, Ravussin A, Galgani JE, Stadler K, Mynatt RL, Ravussin E, Stephens JM, and Dixit VD (2011) The NLRP3 inflammasome instigates obesity-induced inflammation and insulin resistance. Nat Med 17:179-188. 
Vangoitsenhoven R, Mathieu C, and Van der Schueren B (2012) GLP1 and cancer: friend or foe? Endocr Relat Cancer 19:F77-F88.

Velez M, Peterson EL, Wells K, Swadia T, Sabbah HN, Williams LK, and Lanfear DE (2015) Association of antidiabetic medications targeting the glucagon-like peptide 1 pathway and heart failure events in patients with diabetes. J Card Fail 21:2-8.

Vilsbøll T (2009) The effects of glucagon-like peptide-1 on the beta cell. Diabetes Obes Metab 11 (Suppl 3):11-18.

Vinolo MAR, Ferguson GJ, Kulkarni S, Damoulakis G, Anderson K, Bohlooly-Y M, Stephens L, Hawkins PT, and Curi R (2011) SCFAs induce mouse neutrophil chemotaxis through the GPR43 receptor. PLoS One 6:e21205.

Wanders D and Judd RL (2011) Future of GPR109A agonists in the treatment of dyslipidaemia. Diabetes Obes Metab 13:685-691.

Wang A, Luo J, Moore W, Alkhalidy H, Wu L, Zhang J, Zhen W, Wang Y, Clegg DJ, $\mathrm{Bin} \mathrm{Xu}$, et al. (2016) GPR30 regulates diet-induced adiposity in female mice and adipogenesis in vitro. Sci Rep 6:34302.

Wang J, Carrillo JJ, and Lin HV (2016a) GPR142 agonists stimulate glucosedependent insulin secretion via Gq-dependent signaling. PLoS One 11:e0154452.

Wang J, Wu X, Simonavicius N, Tian H, and Ling L (2006) Medium-chain fatty acids as ligands for orphan $\mathrm{G}$ protein-coupled receptor GPR84. J Biol Chem 281: 34457-34464.

Wang J, Zheng P, Baribault H, Chui D, Gundel C, and Veniant M (2016b) GPR21 KO mice demonstrate no resistance to high fat diet induced obesity or improved glucose tolerance. F1000Res 5:36.

Wang S, Awad KS, Elinoff JM, Dougherty EJ, Ferreyra GA, Wang JY, Cai R, Sun J, Ptasinska A, and Danner RL (2015) G protein-coupled receptor 40 (GPR40) and peroxisome proliferator-activated receptor $\gamma(\operatorname{PPAR} \gamma)$ : an integrated two-receptor signaling pathway. J Biol Chem 290:19544-19557.

Weisberg SP, Hunter D, Huber R, Lemieux J, Slaymaker S, Vaddi K, Charo I, Leibel RL, and Ferrante AW Jr (2006) CCR2 modulates inflammatory and metabolic effects of high-fat feeding. J Clin Invest 116:115-124.

Wellendorph P and Bräuner-Osborne H (2009) Molecular basis for amino acid sensing by family C G-protein-coupled receptors. Br J Pharmacol 156:869-884.

Wellendorph P, Johansen LD, Jensen AA, Casanova E, Gassmann M, Deprez P, Clément-Lacroix P, Bettler B, and Bräuner-Osborne H (2009) No evidence for a bone phenotype in GPRC6A knockout mice under normal physiological conditions. J Mol Endocrinol 42:215-223.

Wiberg S, Hassager C, Schmidt H, Thomsen JH, Frydland M, and Lindholm MG, Høfsten DE, Engstrøm T, Køber L, Møller JE, and Kjaergaard J. (2016) Neuroprotective effects of the glucagon-like peptide-1 analog exenatide after out-of hospital cardiac arrest clinical perspective. Circulation 134:2115-2124.

Wier WG and Morgan KG (2003) Alpha1-adrenergic signaling mechanisms in contraction of resistance arteries. Rev Physiol Biochem Pharmacol 150:91-139.

Wilcox G (2005) Insulin and insulin resistance. Clin Biochem Rev 26:19-39.

Willard FS, Bueno AB, and Sloop KW (2012) Small molecule drug discovery at the glucagon-like peptide-1 receptor. Exp Diabetes Res 2012:709893.

Williams CA, Shih MF, and Taberner PV (1999) Sustained improvement in glucose homeostasis in lean and obese mice following chronic administration of the beta 3 agonist SR 58611A. Br J Pharmacol 128:1586-1592.

Williamson RT (1901) On the treatment of glycosuria and diabetes mellitus with sodium salicylate. BMJ 1:760-762.

Willis MS, Ilaiwy A, Montgomery MD, Simpson PC, and Jensen BC (2016) The alpha$1 \mathrm{~A}$ adrenergic receptor agonist $\mathrm{A} 61603$ reduces cardiac polyunsaturated fatty acid and endocannabinoid metabolites associated with inflammation in vivo. Metab olomics 12:155.

Wing RR, Bolin P, Brancati FL, Bray GA, Clark JM, Coday M, Crow RS, Curtis JM, Egan CM, Espeland MA, et al.; Look AHEAD Research Group (2013)
Cardiovascular effects of intensive lifestyle intervention in type 2 diabetes. $N E n g l$ J Med 369:145-154.

Wise A, Gearing K, and Rees S (2002) Target validation of G-protein coupled receptors. Drug Discov Today 7:235-246.

Wong TP, Chan LKY, and Leung PS (2015) Involvement of the niacin receptor GPR109a in the local control of glucose uptake in small intestine of type 2 diabetic mice. Nutrients 7:7543-7561.

Wootten D, Miller LJ, Koole C, Christopoulos A, and Sexton PM (2017) Allostery and biased agonism at class B G protein-coupled receptors. Chem Rev 117:111-138.

Wootten D, Reynolds CA, Smith KJ, Mobarec JC, Koole C, Savage EE, Pabreja K, Simms J, Sridhar R, Furness SGB, et al. (2016) The extracellular surface of the GLP-1 receptor is a molecular trigger for biased agonism. Cell 165:1632-1643.

Wree A, Broderick L, Canbay A, Hoffman HM, and Feldstein AE (2013) From NAFLD to NASH to cirrhosis: new insights into disease mechanisms. Nat Rev Gastroenterol Hepatol 10:627-636.

Wu Q, Wang H, Zhao X, Shi Y, Jin M, Wan B, Xu H, Cheng Y, Ge H, and Zhang Y (2013) Identification of G-protein-coupled receptor 120 as a tumor-promoting receptor that induces angiogenesis and migration in human colorectal carcinoma Oncogene 32:5541-5550.

Wurtman RJ and Anton-Tay F (1969) The mammalian pineal as a neuroendocrine transducer. Recent Prog Horm Res 25:493-522.

Xiao X, Gaffar I, Guo P, Wiersch J, Fischbach S, Peirish L, Song Z, El-Gohary Y, Prasadan K, Shiota C, and Gittes GK (2014) M2 macrophages promote beta-cell proliferation by up-regulation of SMAD7. Proc Natl Acad Sci U S A 111:E1211-20.

Xu J, Morinaga H, Oh D, Li P, Chen A, Talukdar S, Mamane Y, Mancini JA Nawrocki AR, Lazarowski E, et al. (2012) GPR105 ablation prevents inflammation and improves insulin sensitivity in mice with diet-induced obesity. J Immunol 189: 1992-1999.

Yalow RS and Berson SA (1960) Immunoassay of endogenous plasma insulin in man. $J$ Clin Invest 39:1157-1175.

Yang JW, Kim HS, Im JH, Kim J-W, Jun DW, Lim SC, Lee K, Choi JM, Kim SK, and Kang KW (2016) GPR119: a promising target for nonalcoholic fatty liver disease. FASEB J 30:324-335.

Yokomizo T, Izumi T, and Shimizu T (2001) Leukotriene B4: metabolism and signal transduction. Arch Biochem Biophys 385:231-241.

Yu M, Lizarzaburu M, Motani A, Fu Z, Du X, Liu JJ, Jiao X, Lai S, Fan P, Fu A, et al. (2013) Aminopyrazole-phenylalanine based GPR142 agonists: discovery of tool compound and in vivo efficacy studies. ACS Med Chem Lett 4:829-834.

Zaccardi F, Htike ZZ, Webb DR, Khunti K, and Davies MJ (2016) Benefits and harms of once-weekly glucagon-like peptide-1 receptor agonist treatments: a systematic review and network meta-analysis. Ann Intern Med 164:102-113.

Zhang H, Sturchler E, Zhu J, Nieto A, Cistrone PA, Xie J, He L, Yea K, Jones T, Turn R, et al. (2015) Autocrine selection of a GLP-1R G-protein biased agonist with potent antidiabetic effects. Nat Commun 6:8918.

Zhang S, Ma Y, Li J, Ma J, Yu B, and Xie X (2014) Molecular matchmaking between the popular weight-loss herb Hoodia gordonii and GPR119, a potential drug target for metabolic disorder. Proc Natl Acad Sci USA 111:14571-14576.

Zhang Y, Sun B, Feng D, Hu H, Chu M, Qu Q, Tarrasch JT, Li S, Sun Kobilka T, Kobilka BK, et al. (2017) Cryo-EM structure of the activated GLP-1 receptor in complex with a G protein. Nature 546:248-253.

Zheng Y, Qin L, Zacarías NVO, de Vries H, Han GW, Gustavsson M, Dabros M, Zhao C, Cherney RJ, Carter P, et al. (2016) Structure of CC chemokine receptor 2 with orthosteric and allosteric antagonists. Nature 540:458-461.

Zweemer AJM, Nederpelt I, Vrieling H, Hafith S, Doornbos MLJ, de Vries H, Abt J, Gross R, Stamos D, Saunders J, et al. (2013) Multiple binding sites for small-molecule antagonists at the CC chemokine receptor 2. Mol Pharmacol 84:551-561. 